\title{
5. századi településrészlet és temető Nyíregyháza határában. Csorda-Páskum II., M3-58. lelöhely
}

\section{Archaeologiai Értesítő}

$146(2021) 107-154$

D0I:

$10.1556 / 0208.2021 .00020$

(c) 2021 A szerző(k)

\section{Közlemény}

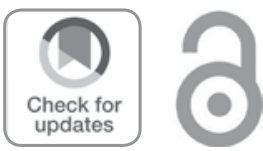

\section{Beck Attila ${ }^{1}$ (D) - Rácz Zsófia ${ }^{2 *}$ (D) - Soós Eszter ${ }^{3}$ (D) - Pintye Gábor ${ }^{4}$}

${ }^{1}$ BTM Aquincumi Múzeum; 1031 Budapest, Szentendrei út 135.;

e-mail: beck.attila793@gmail.com

${ }^{2}$ Eötvös Loránd Tudományegyetem, Régészettudományi Intézet; 1088 Budapest, Múzeum krt. 4/B;

${ }^{3}$ Pécsi Tudományegyetem, Régészet Tanszék; 7624 Pécs, Rókus u. 2.;

e-mail: soos.eszter@pte.hu

${ }^{4}$ Várkapitányság Integrált Területfejlesztési Központ Nonprofit Zrt.,

Régészeti és Tudományos Igazgatóság; 1113 Budapest, Daróczi út 3.;

e-mail: pintye.gabor@varkapitanysag.hu

Kézirat beérkezett: 2021. augusztus 13. Kézirat elfogadva: 2021. augusztus 27.

\section{ABSZTRAKT}

Nyíregyháza határában 2009-2011 során egy temető és egy településrészlet került feltárásra, melyeket a régészeti adatok alapján egyazon népesség használt az 5. század közepén - második felében. A szórt szerkezetű település közelében létesített, 24 síros temetkezőhely olyan temetőtípust képvisel, amely eddig nem volt ismert Északkelet-Magyarországról. Leletanyagában megjelennek a hun korszak és az azt követő évtizedek reprezentatív tárgytípusai, köztük változatos viseleti elemek, üvegpoharak és egy 5 . századi ezüstpénz is.

\section{KULCSSZAVAK}

Nyíregyháza, 5. század, település, temetô, üvegpohár, 5. századi érme

\section{ABSTRACT}

During 2009-2011, a burial ground and a part of a settlement have been excavated within the confines of the Nyíregyháza municipality, which had been used by the same population in the middle and second half of the $5^{\text {th }}$ century AD based on archaeological data. The 24-grave burial ground established near the dispersed settlement represents a previously unknown cemetery type in Northeast Hungary. Representative artefact types from the Hun period and subsequent decades appear in its find assemblage, including a variety of costume items, glass drinking cups, and a $5^{\text {th }}$-century silver coin.

\section{KEYWORDS}

Nyíregyháza, $5^{\text {th }}$ century, settlement, cemetery, glass, $5^{\text {th }}$-century coin

\section{A LELŐHELY}

Az M3-58. számú lelőhely feltárására az M3-as autópálya Nyíregyháza és Vásárosnamény közti szakaszának építését megelőző munkálatok alkalmával került sor. 2009-2010-ben a Magyar Nemzeti Múzeum folytatott itt feltárást Markó András vezetésével, ${ }^{1}$ majd 2011-ben a

${ }^{1}$ Ezúton szeretnénk köszönetet mondani Markó Andrásnak, a Magyar Nemzeti Múzeum régészének, hogy az 5. századi temető és település leletanyagát feldolgozásra a rendelkezésünkre bocsátotta. Hajnal Zsuzsannának is hálásan köszönjük a múzeumi anyagfelvételben, fotózásban nyújtott sok segítséget! Az illusztrációkat A. Király András, Andics Bernadett, Jaksity Iván, Rosta József és Soós Eszter készítette. A régészeti leletanyagot a Magyar Nemzeti Múzeum Népvándorláskori Gyüjteménye őrzi NyíregyházaHarangod néven, 2012.1. kezdetű leltári számok alatt. A település állatcsontanyagát Bárány Annamária vizsgálta meg (ld. Appendix). A feldolgozás az NKFIH NN 128035 sz. projektnek köszönhetően valósulhatott meg. 
terület északi részét a nyíregyházi Jósa András Múzeum munkatársai tárták fel Pintye Gábor irányításával. A lelőhely több néven ismert: kezdetben Nagykállóhoz kötötték, az ásatási jelentés Nyíregyháza-Harangod néven említi, azonban valójában Csorda-Páskum a feltárásoknak helyet adó dűlő megnevezése. ${ }^{2}$ E terület közvetlen közelében került feltárásra 2004-ben Nyíregyháza, keleti elkerülő út 14. számú lelőhelye is, ahol ugyancsak 5. századi településnyomok láttak napvilágot. Pintye Gábor 2016-ban megjelent tanulmányában - amelyben a Jósa András Múzeum által itt feltárt kora népvándorlás kori lelőhelyeket publikálta - ez utóbbit Csorda-Páskum I., míg az általunk tárgyalt helyszínt CsordaPáskum II. néven említi. ${ }^{3}$

Jelen tanulmányunkban a Magyar Nemzeti Múzeum vezetésével 2009-2010-ben feltárt kora népvándorlás kori temetőt és településrészletet adjuk közre. A közel 14000 négyzetméternyi területen több korszak objektumai is megfigyelhetőek voltak, az 5. századi régészeti jelenségeken kívül bronzkori árkok, gödrök és kemencék, valamint egy 8. századi avar épület került napvilágra (1. kép). ${ }^{4}$ A 24 sírból álló temető az ásatási terület közepén, egy észak-déli irányú, enyhén kiemelkedő homokdomb keleti lejtőjén terült el. A síroktól 40-50 méterre, nyugatra helyezkedett el két 5. századi épület és néhány, csupán kevés leletanyagot szolgáltató gödör. A domb déli részén egy avar lakóépület, a dombot körülölelve bronzkori objektumok, főleg gödrök kerültek elö, illetve a felszín északkeleti sarkában egy valószínüleg ugyanebből a korból származó gyermektemetkezés feküdt.

A Nyíregyháza és Nagykálló között fekvő terület a KözépNyírség része. A kistáj 96 és $163 \mathrm{~m}$ tengerszint feletti magasságú hordalékkúpsíkság, melyre jellemző az ÉK-DNy irányú, löszös homokterületek és az ebből 2-25 m-re kiemelkedő futóhomokhátak váltakozása, valamint az ÉÉNyDDK irányú, elzárt medencéket alkotó egykori folyóvölgyek. A terület mezőgazdasági szempontból kedvezőtlen adottságú, a történeti korokban lomboserdővel és szikesekkel volt borított. $^{5}$

\section{A TELEPÜLÉS}

Az 5. századi telepjelenségek a lelőhely északnyugati felében kerültek elö, mély, erősen belvizes területen (2. kép). Egymástól 6-7 méterre két kelet-nyugati tájolású, földbe mélyített épület (18/20 és 22/25), ezektől 35-40 méterre nyugatra, egymáshoz közel, két nagyméretű gödörkomplexum került feltárásra (194/262 és 195/263). Az épületektől észak-északkeletre egy széles, sekély és egy kisebb gödör tartozott még a telephez (4/4, 191/259). A lelöhelyet nyugat-keleti irányban átszelö, nagy bronzkori árokból kerültek elö még kora népvándorlás kori edénytöredékek, többek közt egy nagyméretü, kétfülü korsó darabjai.

\footnotetext{
${ }^{2}$ Markó 2011; Pintye 2016, 67, 1. lábjegyzet, 110, 20. lábjegyzet.

${ }^{3}$ Pintye 2016.

${ }^{4}$ MARKó 2011, 308.

${ }^{5}$ DövÉNYi 2010, 222, 224.
}

\section{Telepjelenségek}

4/4. ${ }^{6}$ gödör (3. kép 1). Átm.: 235 cm. ${ }^{7}$ Enyhén ovális, nagyméretü, sekély gödör. Északnyugati felét egy későbbi beásás elpusztította.

18/20. épület (3. kép 5, 7). H.: $450 \mathrm{~cm}$, sz.: $315 \mathrm{~cm}$. Ny-K tájolású, téglalap alakú, enyhén földbe mélyített épület, keleti és nyugati, rövidebb oldalainak közepén leásott oszlophelyekkel (18/243: átm.: $58 \times 45 \mathrm{~cm}$; 18/242: átm.: 75×60 cm). Egy további, négyszögletes sekély mélyítés az épület közepétől kissé délnyugatra került elő (18/228: átm.: $25 \times 22 \mathrm{~cm})$. Az épület északi oldalának közepén az enyhén lépcsős mélyítés valószínűleg későbbi bolygatás, keleti oldala egy korábbi, valószínűleg őskori gödröt vág $(18 / 138$ : átm.: $160 \times 175 \mathrm{~cm})$.

22/25. épület (3. kép 6, 8). H.: $420 \mathrm{~cm}$, sz.: $260 \mathrm{~cm}$. Ny-K tájolású, téglalap alakú, enyhén földbe mélyített épület, keleti és nyugati, rövidebb oldalai mentén három-három oszlophellyel (22/164: átm.: $30 \times 40 \mathrm{~cm} ; 22 / 165$ : átm.: $45 \times 32 \mathrm{~cm}$; 22/166: átm.: $43 \times 32 \mathrm{~cm}$; 22/168: átm.: $40 \times 35 \mathrm{~cm} ; 22 / 169$ : átm.: $43 \times 38 \mathrm{~cm}$; 22/170: átm.: $23 \times 21 \mathrm{~cm})$. Egy további oszlop a déli oldal mentén volt leásva (22/167: átm.: $46 \times 35 \mathrm{~cm})$.

191/259. gödör (3. kép 2). Átm.: 145×78 cm. Hosszúkás, kissé négyszögletes gödör, alja lépcsősen mélyül.

194/262. gödör (3. kép 3). Átm.: 478×348 cm. Szabálytalan alakú, beásásokkal tagolt, nagyméretü gödörkomplexum. Déli oldalának közepén kis területen lemélyül (194/274), északi fele lépcsősen kialakított (199/275).

195/263. gödör (3. kép 4). Átm.: 390×265 cm. Ovális, szabálytalan, nagyméretű gödör. Oldala lépcsősen szűkül.

A nyíregyházi lelőhely - a környék egykorú településeihez hasonlóan - szórt szerkezetet mutat. ${ }^{8}$ A gödrök kialakítása nem specifikus, a két épület szerkezeti sajátosságai hordoznak régészeti információt.

A 22/25. számú épület (3. kép 6,8) a késő római kori germán Barbaricumban elterjedt típushoz hasonlóan hatoszlopos szerkezetü, ${ }^{9}$ a szélső oszlophelyek azonban nem a hoszszabb oldalak mellett, hanem a sarkokban kerültek leásásra (Eckpfostenhaus). A szerkezettípus a hun kori változásokkal összefüggésben elsősorban a Kárpát-medence északi zónájában terjedt el. ${ }^{10}$ Magyarországon hasonló építmények - az M3-58. lelőhely már korábban közzétett északi részén feltárt épületen kívül ${ }^{11}$ - Andornaktálya-Kis-rét-dülö, ${ }^{12}$ BattonyaVOTsz Homokbánya ${ }^{13}$ és Onga-Teknő lapos $^{14}$ lelőhelyeken kerültek elö Kr. u. 5. századi környezetböl.

\footnotetext{
${ }^{6}$ Objektumszám/stratigráfiai egység száma.

${ }^{7} \mathrm{~A}$ településjelenségek pontos mélységadataihoz nem állt rendelkezésünkre dokumentáció.

${ }^{8}$ BÁLINT et al. 2019, 173.

${ }^{9}$ Kolník et al. 2007, 17, Abb. 7; Soós 2019a, 2. kép 2, 3. kép 1.

${ }^{10}$ Összefoglalóan lásd: Tejral 1990, 28-29, Abb. 3; Tejral 1998, 193-202.

${ }^{11}$ Pintye 2016, 95, 12. kép. Déli sarkaiban azonban nem került elő oszlophely.

${ }^{12}$ BÁLint et al. 2019, 173, 3. kép 1-2.

${ }^{13}$ SzABó 1978, 3-4. ábra.

${ }^{14}$ Soós 2014 , X. t. 8.
} 

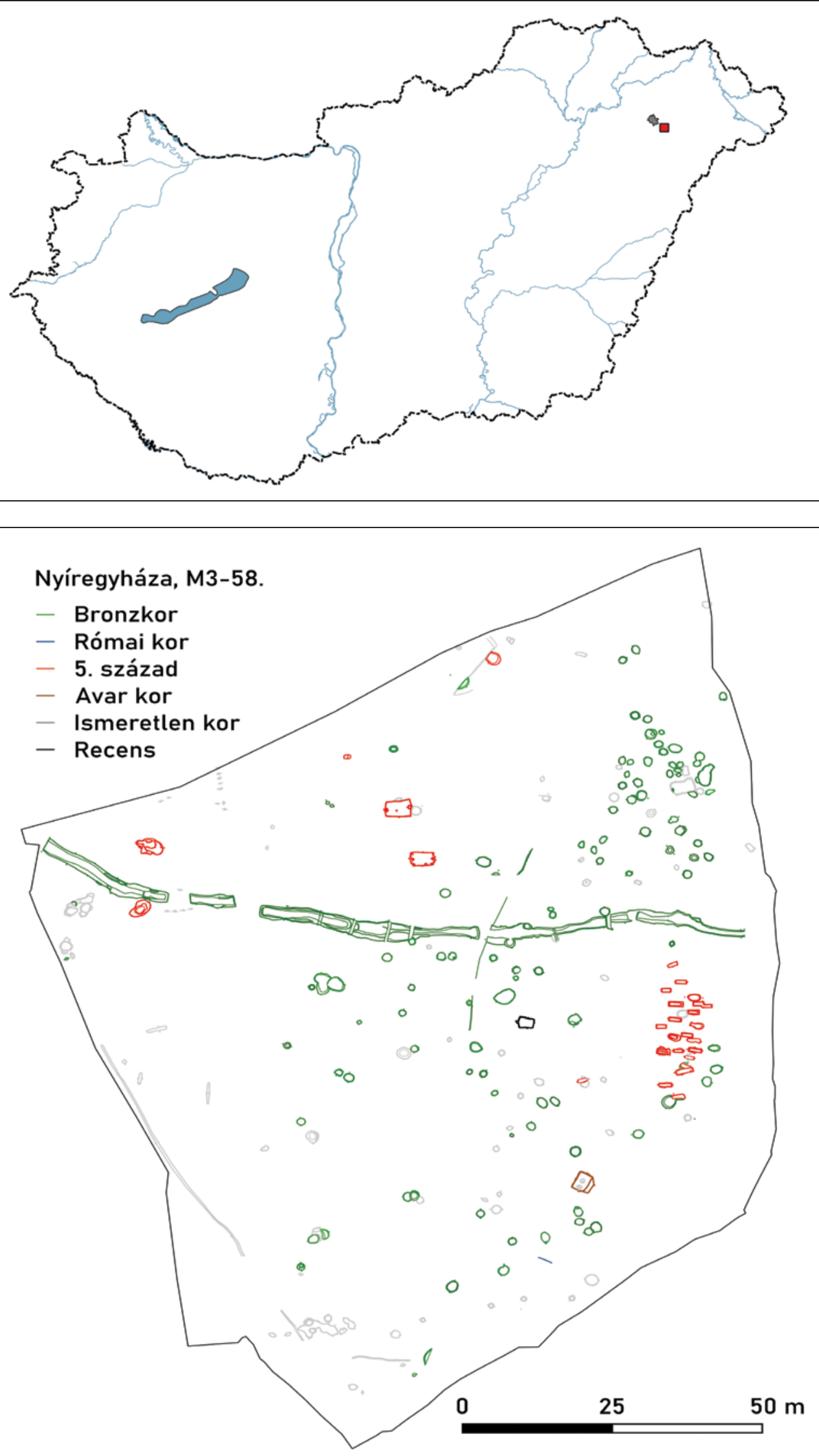

1. kép. Nyíregyháza, M3-58. lelőhely (Csorda-Páskum II.)

Fig. 1. Nyíregyháza, Site M3-58 (Csorda-Páskum II) 


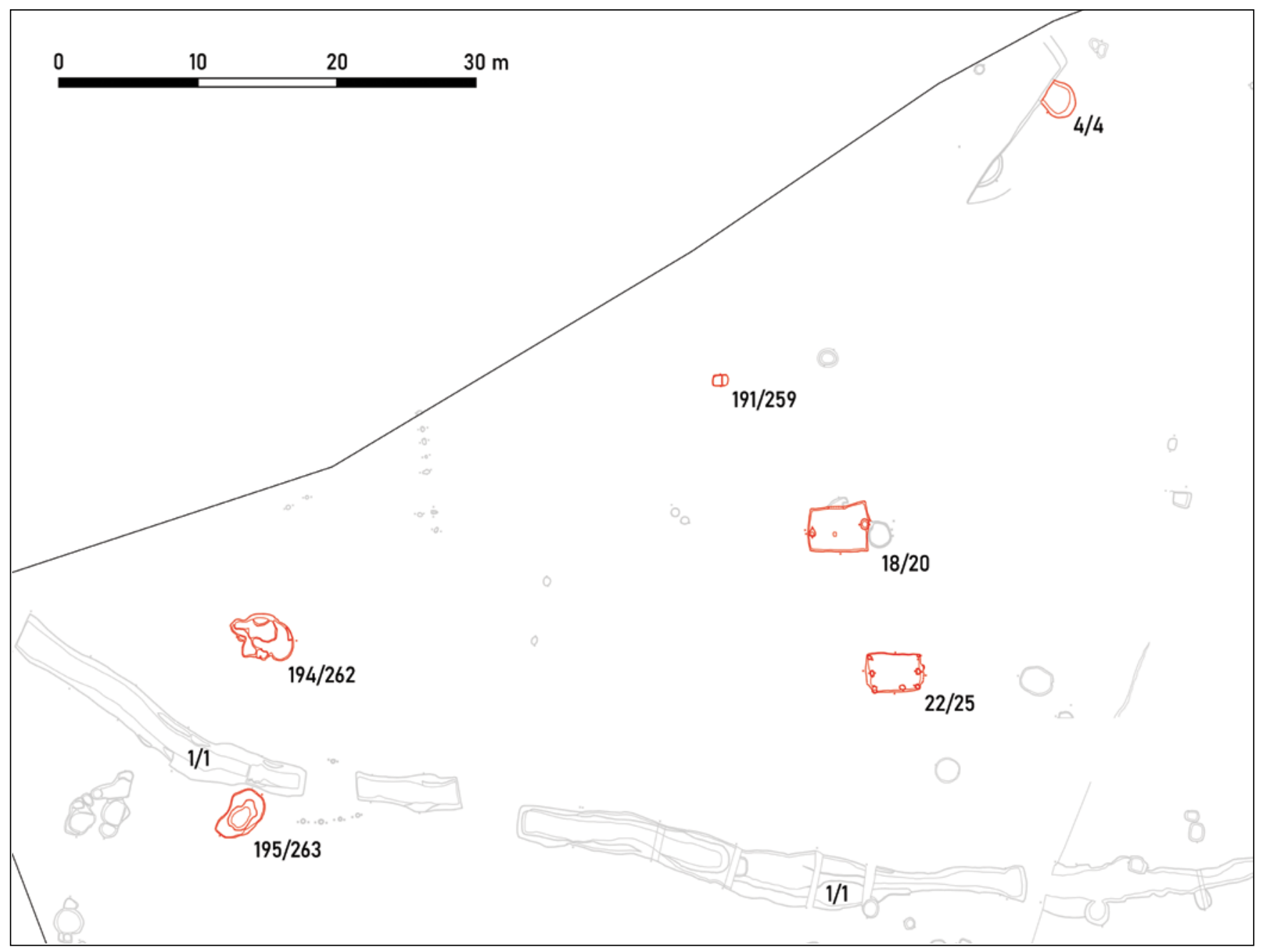

2. kép. M3-58. lelőhely: 5. századi település

Fig. 2. Site M3-58: $5^{\text {th }}$-century settlement

A 18/20. számú épület (3. kép 5, 7) ágasfás-szelemenes szerkezetű volt, rövidebb oldalainak közepén ásták le a tetőt tartó két oszlopot. Az egyszerű szerkezet a késő vaskori - kora római kori népszerüségét követően nem volt jellemző építmény a Kárpát-medence északkeleti részén, újbóli felbukkanása szintén az 5. századra tehető. Az 58. lelőhely északi részén és a közeli 14. lelöhelyen feltárt egy-egy épület ugyanilyen típusú volt, ${ }^{15}$ Onga-Teknő lapos lelőhelyen - az M3-58. lelőhelyhez hasonlóan - szintén hatoszlopos épülettel együtt került elő az 5. század második feléből. ${ }^{16}$ Az egyszerü szerkezet a későbbi évszázadban is továbbélt, mint a gepida kori Alföld leggyakoribb épülettípusa. ${ }^{17}$

\footnotetext{
${ }^{15}$ Pintye 2016, 69, 5. kép, 95, 13. kép.

${ }^{16}$ Soós 2014, 188, VI. t. 1. Pintye Gábor információi alapján a környék egyes késő szarmata lelöhelyein is megfigyelték ezt a háztípust: Nagykálló, Kis-Ludastói-dűlő (ScholTz 2019, 75) és M3-181. lelöhelyeken egy-egy esetben.

${ }^{17}$ MaseK 2015, 419.
}

\section{A település leletanyaga}

A csekély számú, töredékes 5. századi kerámia leletanyag különleges darabokat nem tartalmazott, de technológiai és formai jellegzetességei jól párhuzamba állíthatóak a FelsőTisza vidékről eddig publikált, hasonló korú leletanyagokkal.

A régészeti jelenségekből csupán félszáz edénytöredék került elő, melyek pár kézzel formált darabon kívül gyorskorongolt edényekhez tartoztak. Finom, soványítatlan agyagból szürkére és sötétszürkére égetett korsók és tálak készültek, egyetlen vastag falú tárolóedény vagy hombár esetében lehetett oxidációs égetést azonosítani. A durvább, szemcsés anyag szinte kivétel nélkül fazekakra jellemző: ezek többsége szitált apró kővel, kaviccsal erősen kevert agyagból formált, mellettük kevesebb, de nagyobb szemcséket tartalmazó félfinom, és homokosabb anyagú darabok is megfigyelhetőek. A fazekak esetében is dominált a redukciós égetés; megfigyelhető, hogy a finomabb anyagúak felületét sötétebbre égették, a feltűnő sárgás és vöröses-barnás árnyalatok inkább másodlagos égés nyomai. A korongolt edények esetében éles technológiai különbséget nem lehet megállapítani, erősebben soványított 
1.táblázat. A nyíregyházi M3-58. lelőhely telepkerámiájának technológiai és formai megoszlása (edényszám/töredékszám) Table 1. Nyíregyháza, Site M3-58. Ceramics from the settlement according to technology and form (number of vessels/fragments)

\begin{tabular}{|c|c|c|c|c|c|c|c|c|}
\hline & & korsó & tál & bögre & fazék & hombár & nem megh. & össz. \\
\hline \multirow{4}{*}{ Korongolt } & Finom, soványítatlan & $3 / 3$ & $3 / 3$ & & & $1 / 2$ & $4 / 5$ & $11 / 13$ \\
\hline & Kevés kő & & & $1 / 4$ & $4 / 7$ & & & $5 / 11$ \\
\hline & Erősen kavicsos & & & & $11 / 18$ & & & $11 / 18$ \\
\hline & Homokos-kavicsos & & & & $3 / 10$ & & & $3 / 10$ \\
\hline \multicolumn{2}{|c|}{ Kézzel formált } & & $2 / 3$ & & $3 / 4$ & & & $5 / 7$ \\
\hline \multicolumn{2}{|l|}{ Összesen } & $3 / 3$ & $5 / 6$ & $1 / 4$ & $21 / 39$ & $1 / 2$ & $4 / 5$ & $35 / 59$ \\
\hline
\end{tabular}

darabok felületén is megfigyelhetö fényezés, mintegy átmenetet képezve a finom áru irányába. A pár kézzel formált tál és fazék anyaga rosszul eldolgozott, erősen homokos, szemcsés, égetésük eltér a korongolt daraboktól, színük vöröses-sárgás vagy barnás (1. táblázat).

A kerámia leletanyag edénytípusok szerinti megoszlása: a finom korsók viszonylag magas aránya, a szemcsés fazekak dominanciája és a kézzel formált anyag minimális jelenléte jól párhuzamba állítható a Felső-Tisza-vidékről ismert 5. századi települések leletanyagának összetételével. ${ }^{18}$ Nyíregyházán a telepkerámia kis mennyisége és töredékessége miatt elemzésbe csak pár kiemelt darab vonható.

A kétfülü, nyakpárnás, gömbös testü, nagyméretü korsó vállát egy sávban hálós besimítás díszíti, széles szalagfülén kettős árkolás fut végig (4. kép). A szűk, tagolt nyakú, nyakból induló fülü korsók magasabb arányban a késő római kori, Felső-Tisza-vidéki településeken találhatóak meg, ${ }^{19}$ ekkor még kerek átmetszetü füllel. A nyíregyházi korsó legjobb formai analógiái a D2/D3 periódusra datált rákóczifalvi 2. horizont edényei közül említhetőek, ott jellemzően egy, de széles szalagfüllel voltak ellátva. ${ }^{20}$ Közvetlen párhuzama eddig nem ismert.

A nyakpárnás, fényezett felületü, füles korsó töredéke (6. kép 5) a 6. sír korsójához hasonlóan a Murga-típushoz sorolható. A bikónikus, durván fényezett felületü tál (5. kép 11) legjobb analógiái a szomszédos 14 . lelöhelyről ismertek. ${ }^{21}$ A finom tálak közül az S-profilú jellegzetesen 5. századi forma (5. kép 7), mely Pannonia késő római anyagában bukkant fel elöször, de igen jellemző barbár területen is a hun korban újonnan alapított településekre. ${ }^{22}$ A 6 . századi gepida lelőhelyeken már más táltípusokkal találkozunk. ${ }^{23}$

\footnotetext{
${ }^{18} \mathrm{Pl}$. Hernádvécse (Soós et al. 2017, 81, Tab. 3), részletesen: Soós 2019b, 730-731, Abb. 19.

${ }^{19}$ Istvánovits 1999, Pl. X, 1-2, Pl. XVI, 5, Pl. XXIV, 2; GindeleIstvánovits 2009, 39-40, Abb. 53; Soós 2016, 458, Fig. 5; MASEK 2018, 127-128.

${ }^{20}$ MaseK 2018, 242, 153. kép, 342.

${ }^{21}$ Pintye 2016, XXVI. t. 2, 5-7, XXVII. t. 3-4.

${ }^{22}$ Soós et al. 2017, 62, Fig. 11; Bocsi 2016, 75-76, 20 . kép 1.

${ }^{23}$ B. То́тн 2006, Taf. 19-20.
}

Egy enyhén szemcsés anyagú, alsó harmadban hasasodó bögre felülete enyhén fényezett, vállán finom, ferde vonalakkal díszített (5. kép 8). A forma szintén az 5. század középső harmadára keltezhető lelőhelyeken bukkant fel először, mint Hernádvécse, ${ }^{24}$ Onga-Teknő lapos vagy BiharkeresztesÁrtánd. ${ }^{25}$ Használata a későbbi évszázadban is tovább követhető, kis méretben és bepecsételt díszítéssel a gepida leletanyag csak alacsony számban megjelenő, de meghatározó részét képezték a kettős kónikus mellett az ívelt hasú bögrék is. ${ }^{26}$

A szemcsés fazekak közt fedőhornyos és egyszerü, közepesen kihajló peremü darabok is találhatóak (5. kép 4, 6, 10; 6. kép 2). Többségük durva kidolgozású; jó minőségü, vékonyfalú, keményre égetett darabok, mint Hernádvécsén vagy Andornaktályán, nem kerültek elő. ${ }^{27}$

Érdekes formai párhuzamokat mutat egy széles, ferdén befelé megvastagodó peremü, nyakon széles korongolt bordával ellátott, szemcsés edény (5. kép 3). Hasonló kialakítású fazekak nem találhatóak sem a hun korban újonnan alapított, sem a gepida kori telepanyagokban. A forma erősen emlékeztet a szarmata cilindrikus peremü, finom anyagból készült edényekre, melyek a 4. század második felétől jelentek meg nagyobb számban az alföldi leletanyagban. ${ }^{28}$ Az edény úgy interpretálható, mint egy hun kori szarmata típus eltérő technológiával készített változata, melynek a későbbi anyagokban nem található folytatása. A jelenség nem egyedi: az ongai szemcsés, gyürüs peremű tálaknak is csak a szarmata környezetből hozható formai analógiája. ${ }^{29}$

A kézzel formált darabok közül egy enyhén bikónikus kis tál emelhető ki (6. kép 7). A megtört falú tálkának közvetlen szakirodalmi analógiája eddig nem ismert, egy igen hasonló edényke a Tiszakarád-inasai temető egyik sírjába volt helyezve mellékletként. ${ }^{30}$

\footnotetext{
${ }^{24} \mathrm{Az}$ 5. század első felétől keltezve (Soós et al. 2017, 67, Pl. XVI, 1).

${ }^{25}$ Soós 2014,192 , IX. t. 1.

${ }^{26} \mathrm{~B}$. То́тн 2006, 80.

${ }^{27}$ Soós et al. 2017, 64, Fig. 11; BÁLINT et al. 2019, 177, 5. kép.

${ }^{28}$ MASEK 2018, 115, 121.

${ }^{29}$ Soós 2014, 193, IX. t. 4-6.

${ }^{30}$ Lovász Emese szíves szóbeli közlése.
} 

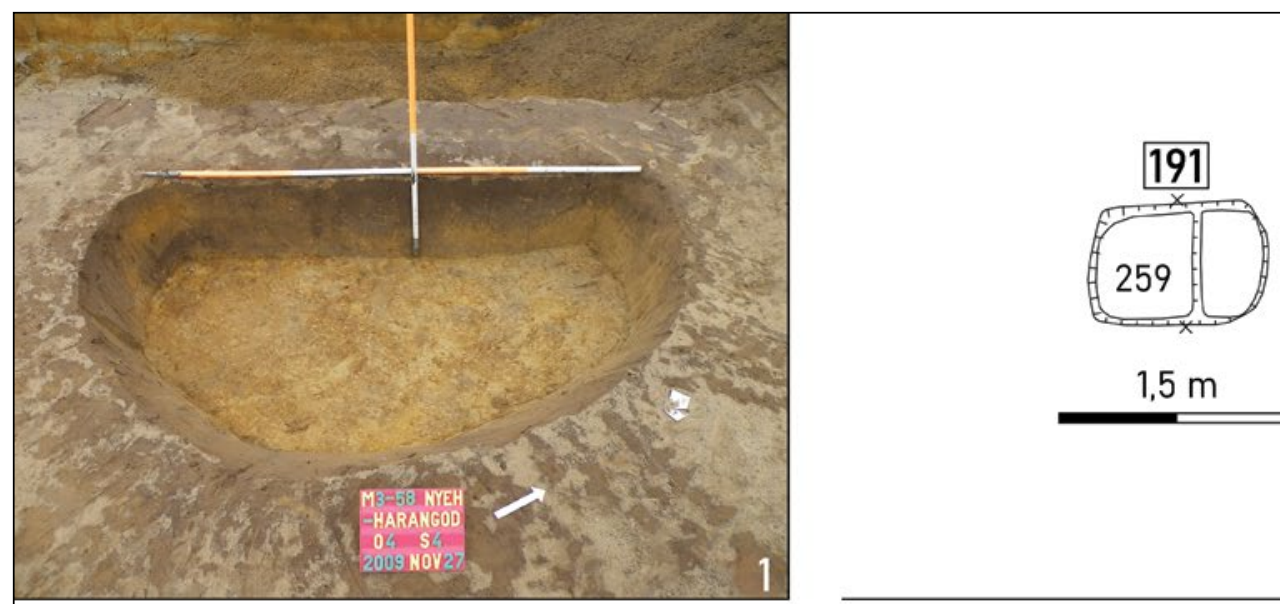

$1,5 \mathrm{~m}$
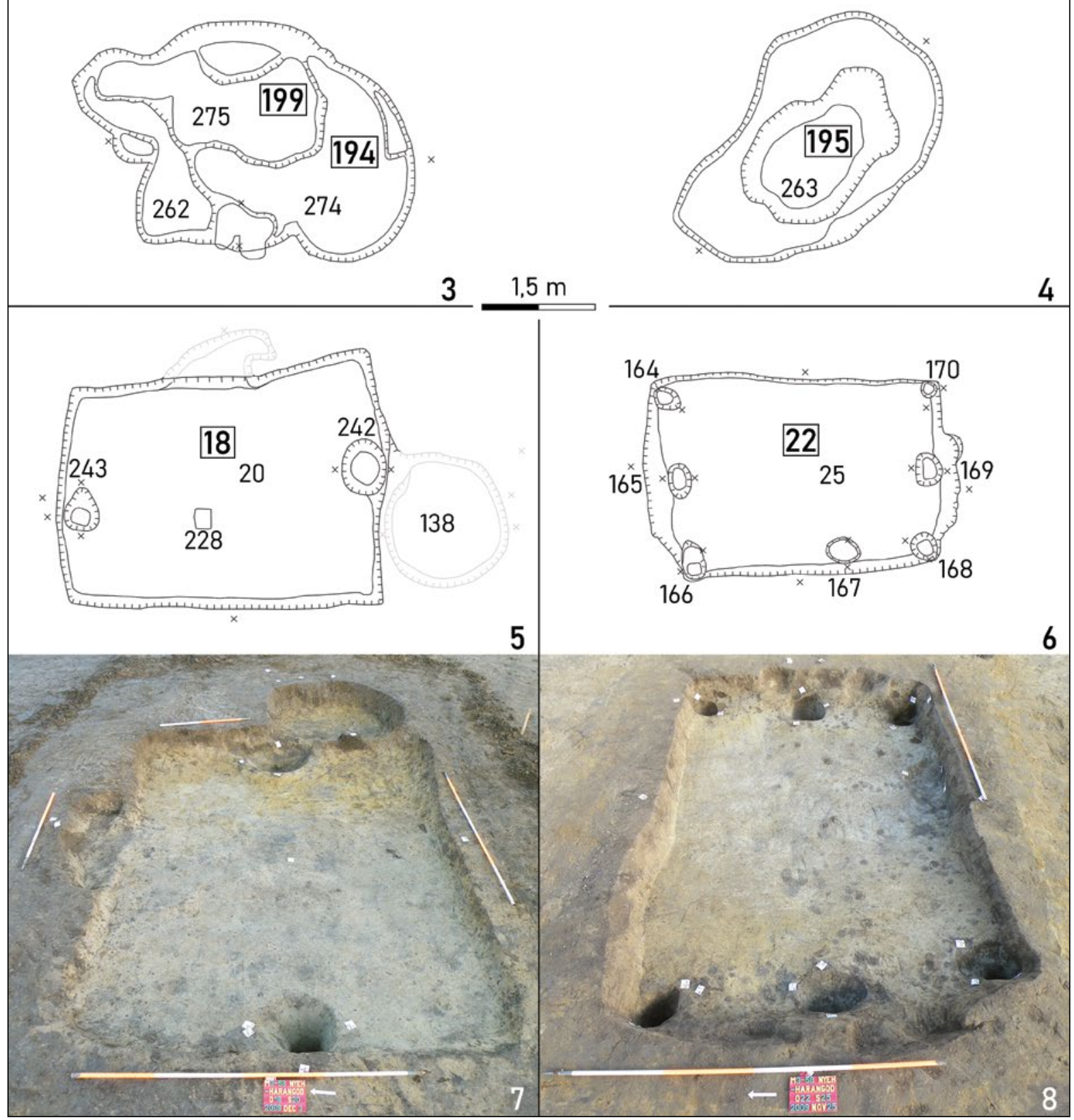

3. kép. M3-58. lelőhely: településobjektumok. 1: 4/4; 2: 191/259; 3: 194/262; 4: 195/263; 5, 7: 18/20; 6, 8: 22/25. objektum

Fig. 3. Site M3-58: settlement features. 1: 4/4; 2: 191/259; 3: 194/262; 4: 195/263; 5, 7: 18/20; 6, 8: 22/25 


\section{A TEMETÓ}

\section{A sírok katalógusa}

1. sír $(53 / 58)^{31}$ (8. kép).

Tájolás: NyDNy-KÉK. Téglalap alakú, erősen bolygatott sírgödör. H.: $170 \mathrm{~cm}$; sz.: $56 \mathrm{~cm}$; m.: 116-126 cm. A nagyméretű bolygatási gödör foltja jól látszott a felszínen. A jobb lábszárcsont kivételével a csontváz nem maradt eredeti helyén. A bordákat és a felkarcsontot a sírgödör nyugati végébe tolták össze. A koponyából csak az állkapocs őrződött meg, a sír közepén helyezkedett el.

Életkor és nem: ${ }^{32} 40-60$ éves nő.

Melléklete nem volt.

2. sír (64/71) (8. kép).

Tájolás: NyDNy-KÉK. Ovális, erősen bolygatott sírgödör, a bolygatási gödör foltja jól kivehetö volt. $H .: 142 \mathrm{~cm}$; sz.: $75 \mathrm{~cm} ; \mathrm{m} .: 79 \mathrm{~cm}$. A váz nem volt anatómiai helyzetben, az emberi maradványok a sír közepén helyezkedtek el: a koponya egy töredéke, az állkapocs lefelé fordulva és néhány hosszúcsont.

Életkor és nem: 7-8 éves gyermek.

Mellékletek: 1. Kétsoros, háromrészes agancsfésű töredéke a sír közepe táján, a csontoktól északra. A díszítetlen fogólap közepén futó bronzszegecsek közül kettő maradt meg. H.: 4,6 cm; sz.: $1,5 \mathrm{~cm}$ fogak nélkül; v.: $0,8 \mathrm{~cm}$; fogak sz.: $0,15 \mathrm{~cm}$. 2. Orsógomb. Elveszett.

3. sír (65/72) (9. kép).

Tájolás: Ny-K. Téglalap alakú, erősen bolygatott sírgödör. H.: $219 \mathrm{~cm}$; sz.: $96 \mathrm{~cm}$; m.: $73 \mathrm{~cm}$. A koponya a sír nyugati részében kifordulva feküdt, a bordák hiányoznak, a combcsontok a sírgödör közepén helyezkedtek el. A lábszár csontjai a helyükön voltak. A bolygatási gödör jól megfogható volt, a betöltésből emberi csontok kerültek elö.

Életkor és nem: 16-18 éves férfi (?).

Mellékletek: 1. Ezüstcsat, a sír közepén, a másodlagos helyzetű combcsonton feküdt. D alakú, öntött, egyik oldalán kissé megvastagodó karikájú, ovális, lemezes testü, 3 felerősítő szegeccsel. Az ovális szíjbefogó lemez a csatkarikára van hajlítva, hátoldala valamivel keskenyebb az elülső lemeznél. A csatkarikára hajló pecek a tövénél négyzetes kialakítású, két vésett vonallal. $H .: 3,4 \mathrm{~cm}$; karika sz.: $2,6 \mathrm{~cm}$, v.: $0,44 \mathrm{~cm}$, lemezes test sz.: 2,64 cm, lemez v.: $0,06 \mathrm{~cm}$ (19. kép 1). 2. Hasonló, kisebb méretủ ezüstcsat a lábfej csontjainál. Ennek karikája inkább ovális, peckén borda fut végig. $H .: 2,5 \mathrm{~cm}$; karika sz.: $2,15 \mathrm{~cm}$, v.: $0,32 \mathrm{~cm}$, lemezes test sz.: $1,96 \mathrm{~cm}$; lemez v.: $0,1 \mathrm{~cm}$ (19. kép 2). 3. A sír üvegmellékletet is tartalmazhatott,

\footnotetext{
${ }^{31}$ A temető sírjait a leltározás során átszámozták. A zárójelben megadott adatok az objektumszámok és a stratigráfiai egységek számai.

${ }^{32} \mathrm{Az}$ embertani feldolgozás sajnos nem készült el cikkünk lezárásáig, a Nemzeti Múzeum raktárában elérhető csontvázakat azonban Korita Mónika, Hajdu Tamás és Szeniczey Tamás megvizsgálta és az életkorra és nemre vonatkozó adatokat rendelkezésünkre bocsátotta, amit ezúton is hálásan köszönünk.
}

a betöltésében üvegpohár-töredékek kerültek elő: olívazöld, vékonyfalú, hosszúkás-rátétes díszű üvegpohár három darabja: két összeillő perem és oldal, valamint egy oldaltöredék. A perem megvastagodó, melegen lekerekített. A perem alatt egy vékony, körbefutó bordadísz is látható. Oldal v.: $0,05 \mathrm{~cm}$, perem v.: $0,38 \mathrm{~cm}$. Perem átm.: kb. $9 \mathrm{~cm}(21$. kép).

4. sír $(67 / 74)$ (8. kép).

Tájolás: NY-K. Téglalap alakú temetkezés, a sírt az egész területén megbolygatták, a bolygatási gödör foltja jól látszott. H.: $210 \mathrm{~cm}$; sz.: $125 \mathrm{~cm}$; m.: $82 \mathrm{~cm}$. A koponya a bal oldalán feküdt, mögötte $10 \mathrm{~cm}$-rel az állkapocs. A koponyától keletre a lapockák hozzávetőlegesen a helyükön voltak és a jobb humerus is, de a bal felkarcsont elmozdult. A karok többi csontja, a bordák, illetve a csigolyák egy vonalba rendeződve feküdtek, éppúgy, mint a koponya és a medence. Valószínüleg ez a vonal lehetett a bolygatási gödör északi széle, ahová félretolták a csontvázat. A medencétől keletre volt a két combcsont, a láb többi része hiányzik. A csontok egy része a betöltésből került elö.

Életkor és nem: 30-40 éves férfi.

Mellékletek: 1. Hosszúkás, csonkakúp alakú, nyolcszög átmetszetű bronztárgy került elő a sír betöltéséből, feltételezhetően (poncoló?) szerszám letört hegye lehetett, a sírhoz tartozása bizonytalan. H.: $2,4 \mathrm{~cm}$, legnagyobb átm.: $0,84 \mathrm{~cm}$.

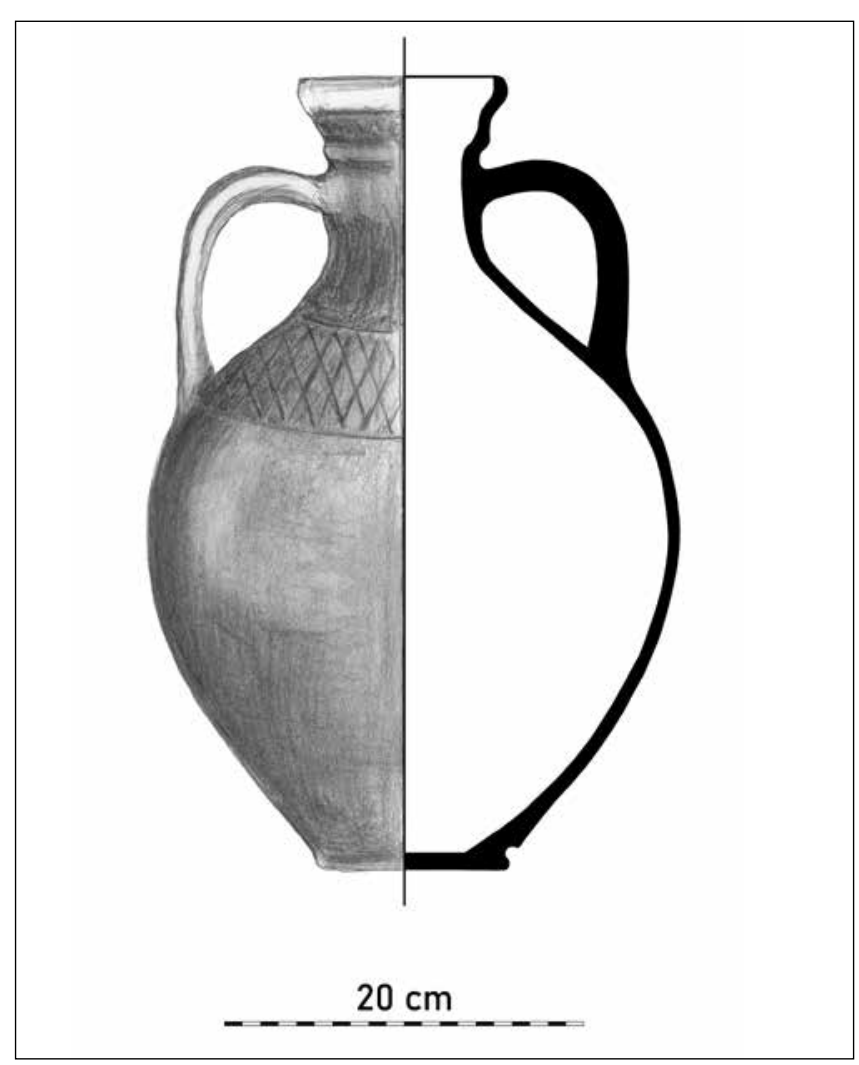

4. kép. M3-58. lelőhely: kétfülű korsó az 1/1. árokból

Fig. 4. Site M3-58: two-handled jug from Ditch 1/1 

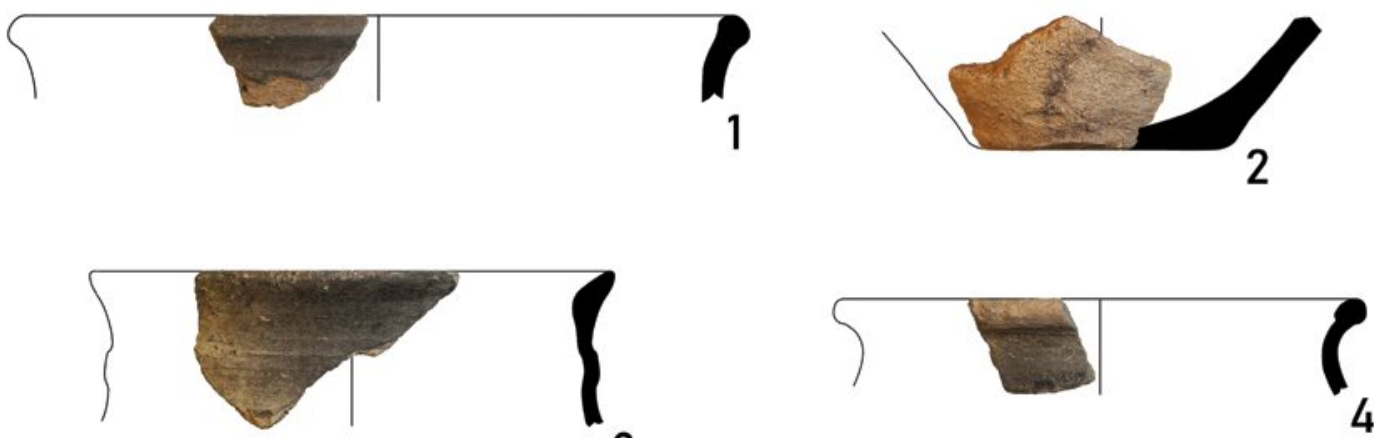

3
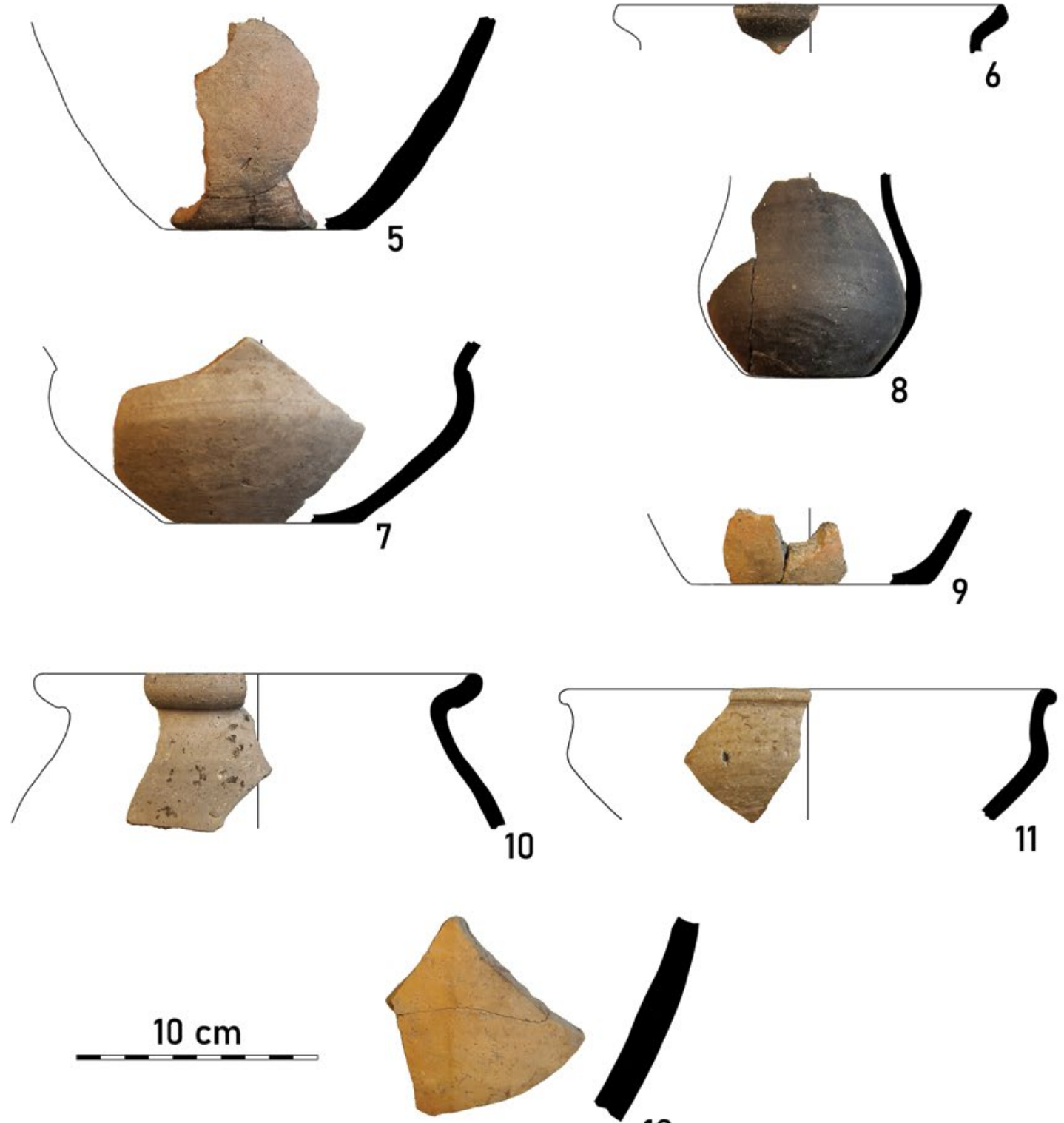

12

5. kép. M3-58. lelőhely: telepkerámia. 1: 1/1;2-5: 4/4; 6-9: 18/20; 10-12: 22/25. objektum

Fig. 5. Site M3-58: ceramics from the settlement. 1: Feature 1/1; 2-5: Feature 4/4; 6-9: Feature 18/20; 10-12: Feature 22/25 

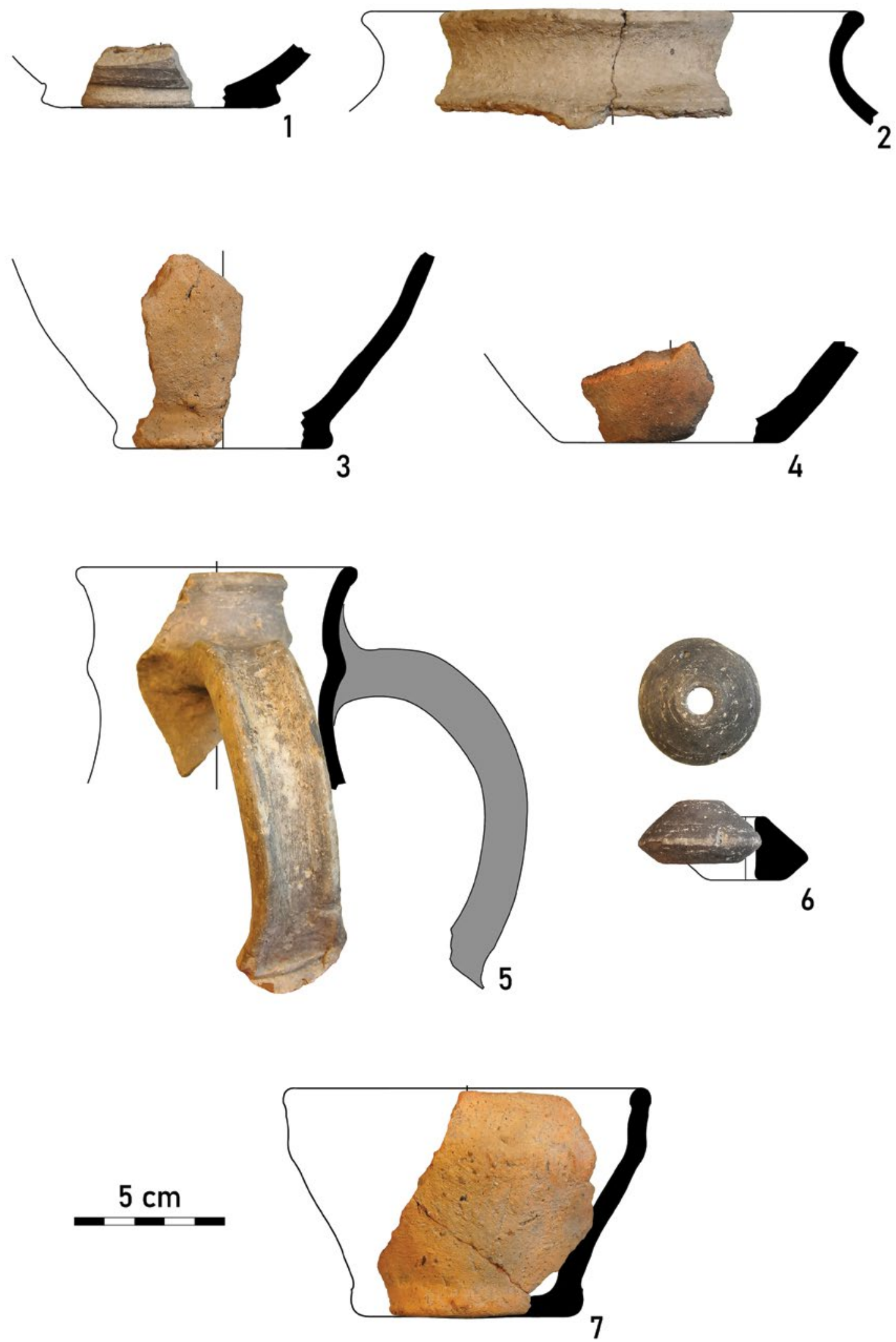

6. kép. M3-58. lelőhely: telepkerámia. 1: 205/284; 2-3, 7: 194/262; 4: 191/259; 5: 195/263; 6: 22/25. objektum

Fig. 6. Site M3-58: ceramics from the settlement. 1: Feature 205/284; 2-3, 7: Feature 194/262; 4: 191/259; 5: Feature 195/263; 6: Feature 22/25

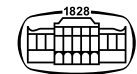




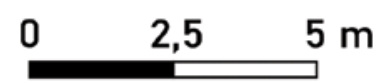

$53 / 58$

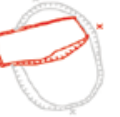

$95 / 115$

$175 / 235$

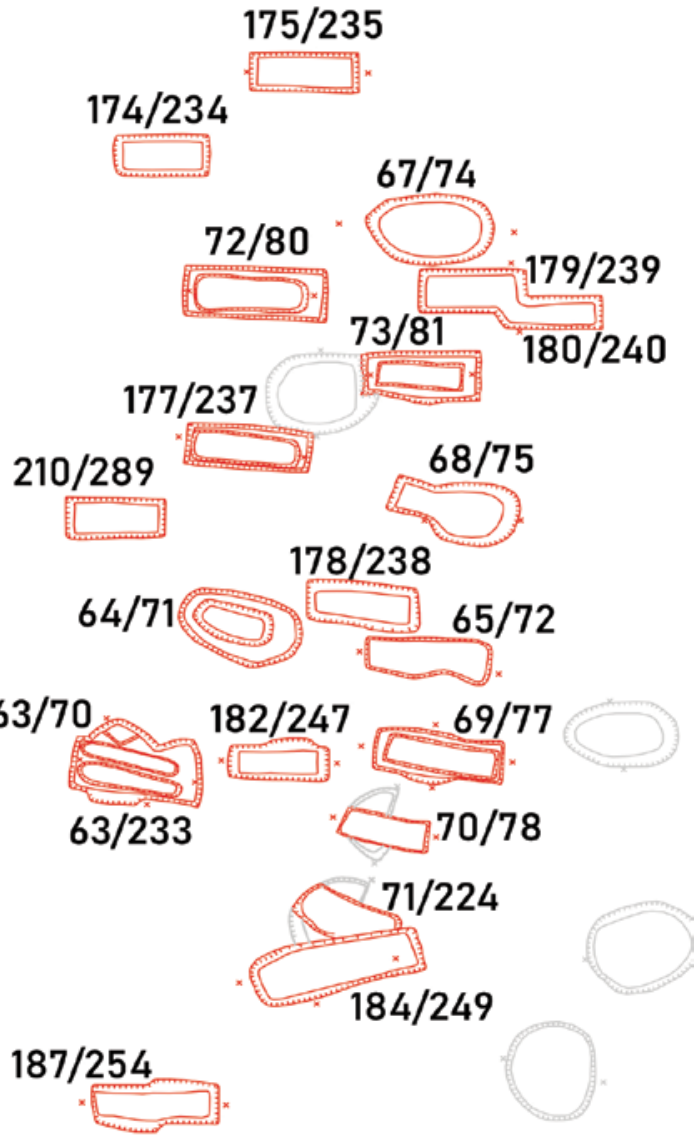

$61 / 225$

\section{7. kép. M3-58. lelőhely: 5. századi temető}

Fig. 7. Site M3-58: $5^{\text {th }}$-century cemetery

5. sír (68/75)

Tájolás: Ny-K. Téglalap alakú, bolygatott sírgödör. H.: $200 \mathrm{~cm}$; sz.: $112 \mathrm{~cm}$; m.: $56 \mathrm{~cm}$. A bolygatás foltja jól látszott, a csontok kizárólag a betöltésből kerületek elő. Sírrajz nincs.

Életkor és nem: 6-9 éves gyermek.

Melléklete nem volt.

6. sír (69/77) (10. kép).

Tájolás: Ny-K. Téglalap alakú, bolygatott sír, a bolygatási gödör jól megfogható volt. H.: $204 \mathrm{~cm}$; sz.: $61 \mathrm{~cm}$; m.: $79 \mathrm{~cm}$. Összesen két hosszúcsont maradt meg a vázból. Életkor és nem: 5-6 éves gyermek.

Mellékletek: 1. Murga-típusú füles korsó a sír nyugati oldalánál. Finom, gyorskorongolt, redukciós égetésű, kö- zépszürke felületű korsó. Pereme széles, enyhén kihajló, válla kónikus, alsó harmadban szélesedő hasa ívelt, alja keskeny talpkorongos. Keskeny, szögletes átmetszetű szalagfüle a nyakon levő bordából indul és a has felső részéhez csatlakozik. Vállán függőleges cikcakk, közöttük hármas, besimított vonalakkal, a has tetején finom árkolással határolt, vízszintes sávban körbefutó, besimított cikcakk vonallal díszített. Mag.: 15,4 cm; perem átm.: 7,8 cm; legnagyobb átm.: $12 \mathrm{~cm}$; alj átm.: $5,6 \mathrm{~cm}$ (25. kép 2). 2. Kisméretű fazék a sír délnyugati sarkában. Szitált köves soványítású, gyorskorongolt, szürkésbarnára égetett kisfazék. Pereme közepesen kihajló, rövid, enyhén hornyolt, hasa erősen ívelt, nyomott, külső és belső felszínén erőteljes korongolásnyomok látszanak. Mag.: $9,3 \mathrm{~cm}$; perem 

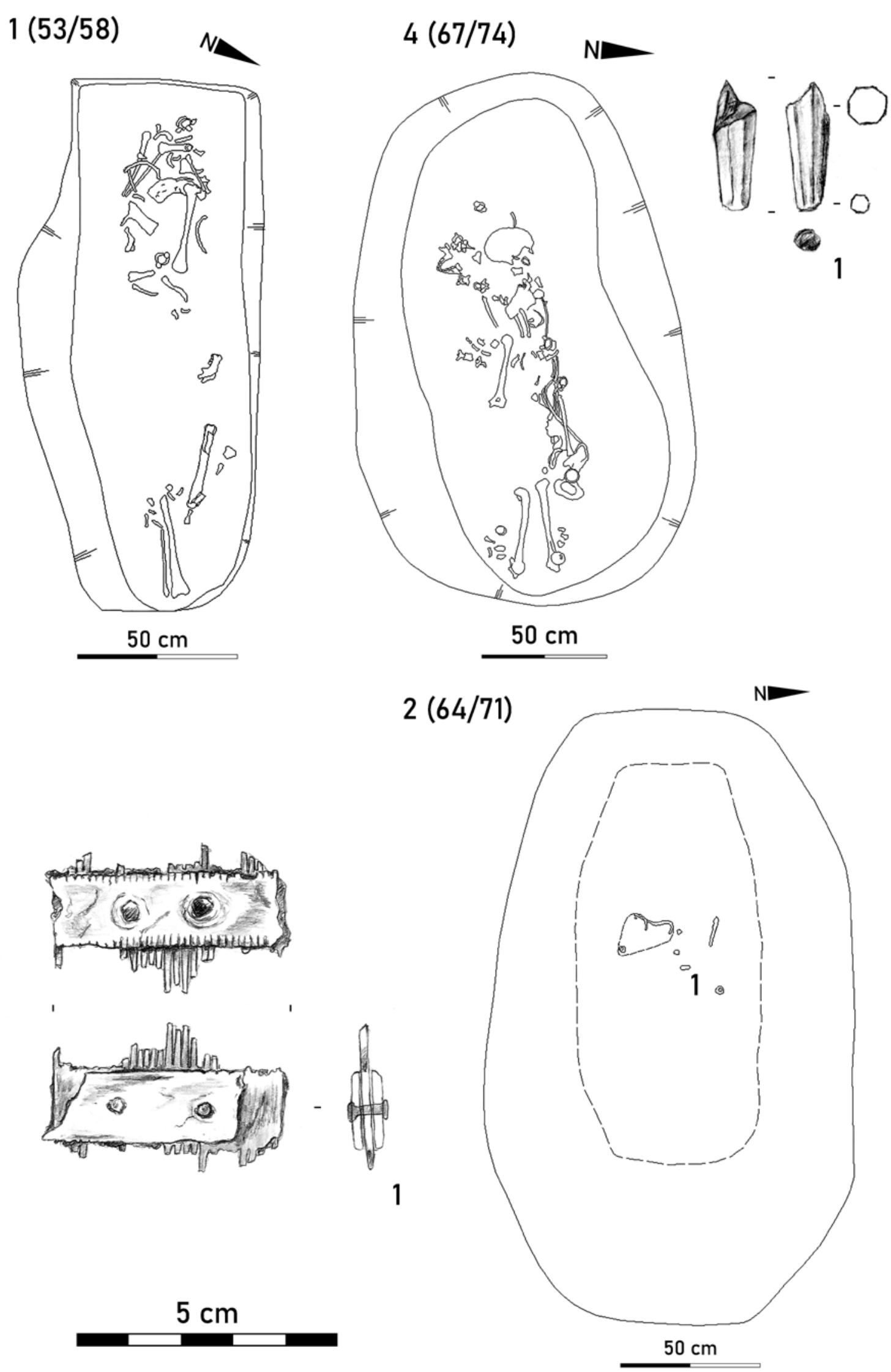

8. kép. M3-58. lelőhely: 1., 2., 4. sír

Fig. 8. Site M3-58: Grave 1, 2, 4 

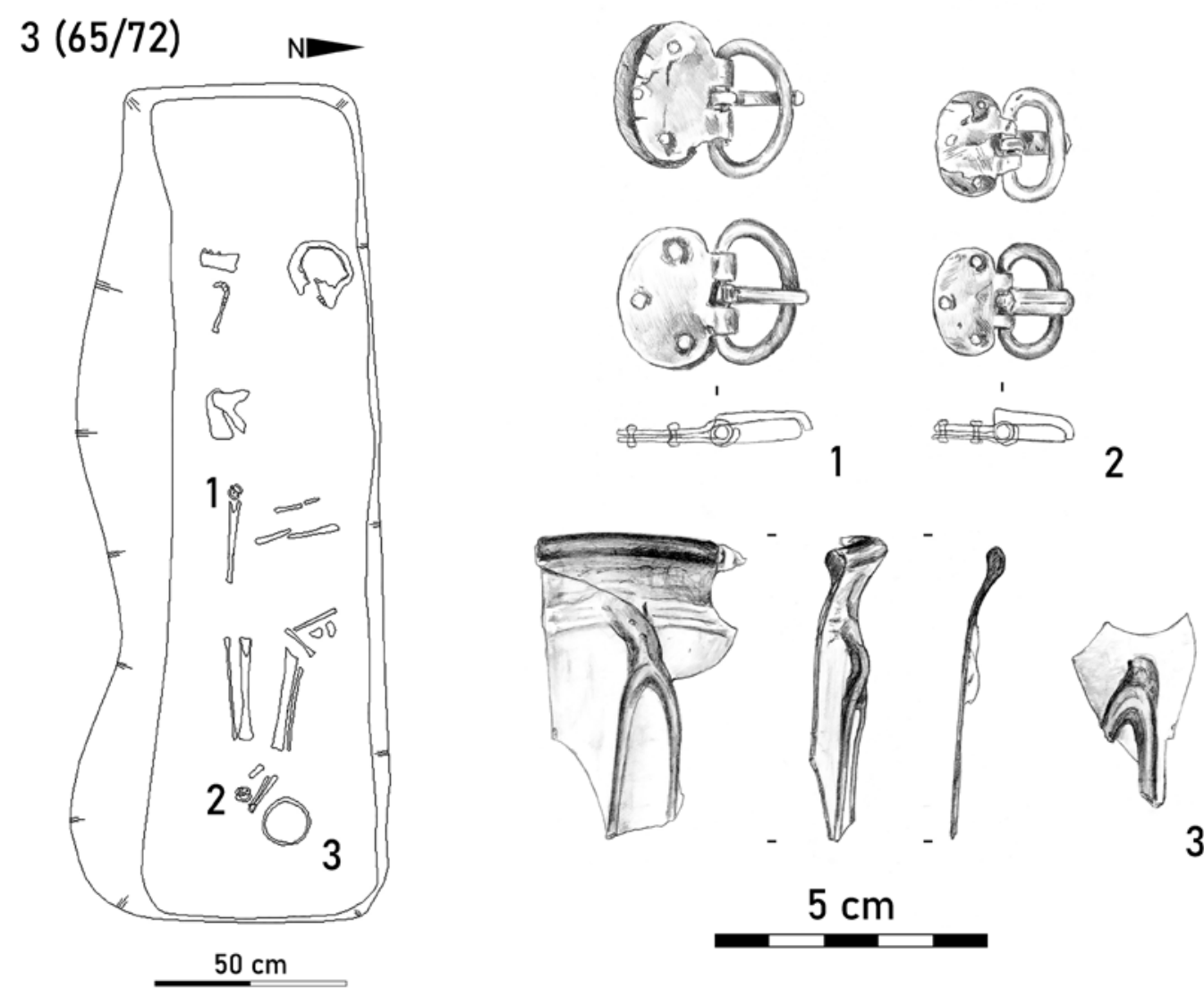

$8(72 / 80)$

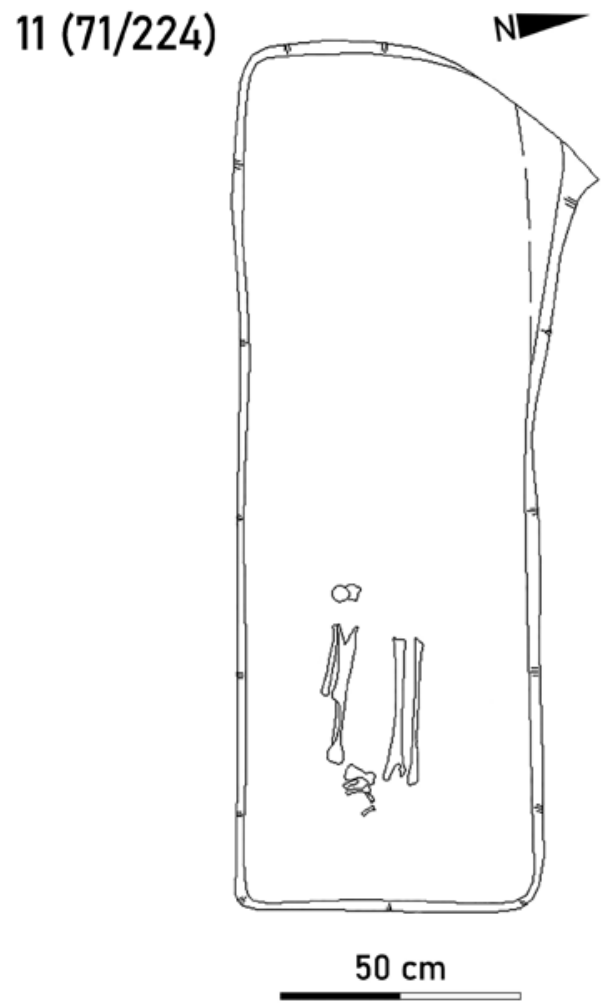

9. kép. M3-58. lelőhely: 3., 8., 11. sír

Fig. 9. Site M3-58: Grave 3, 8, 11 
$6(69 / 77)$

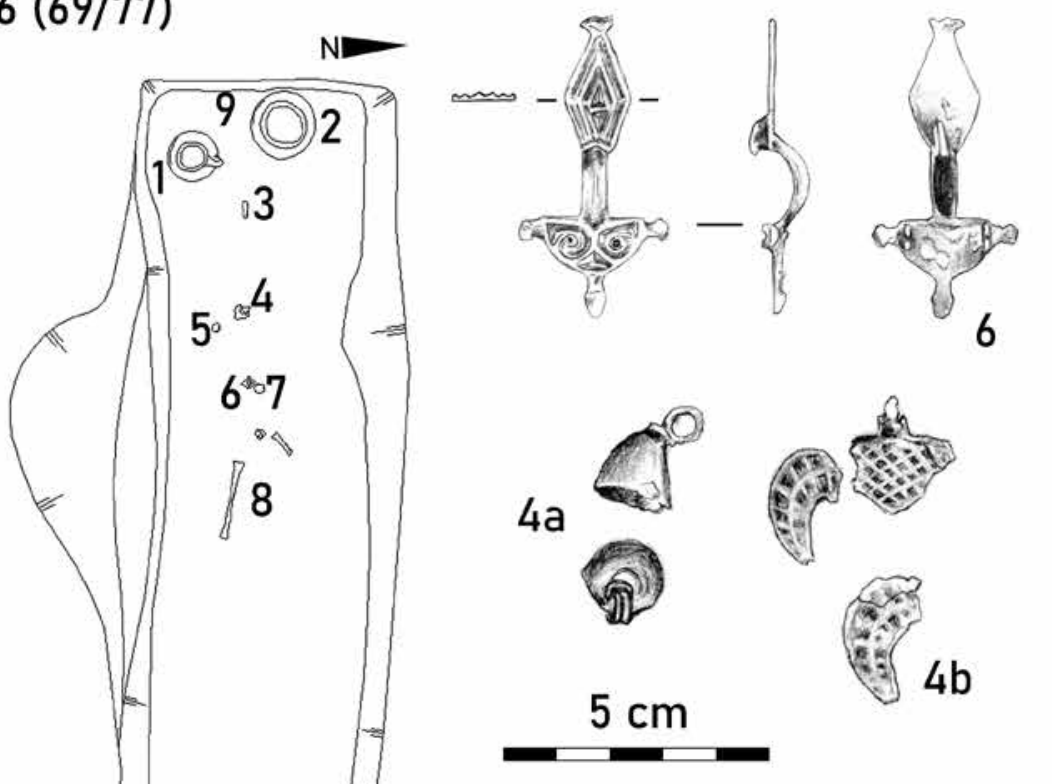

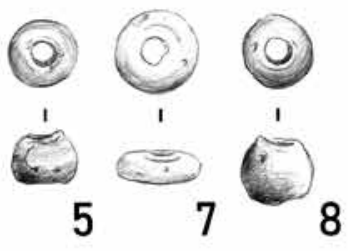

(0.5)

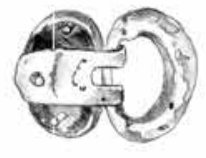

3
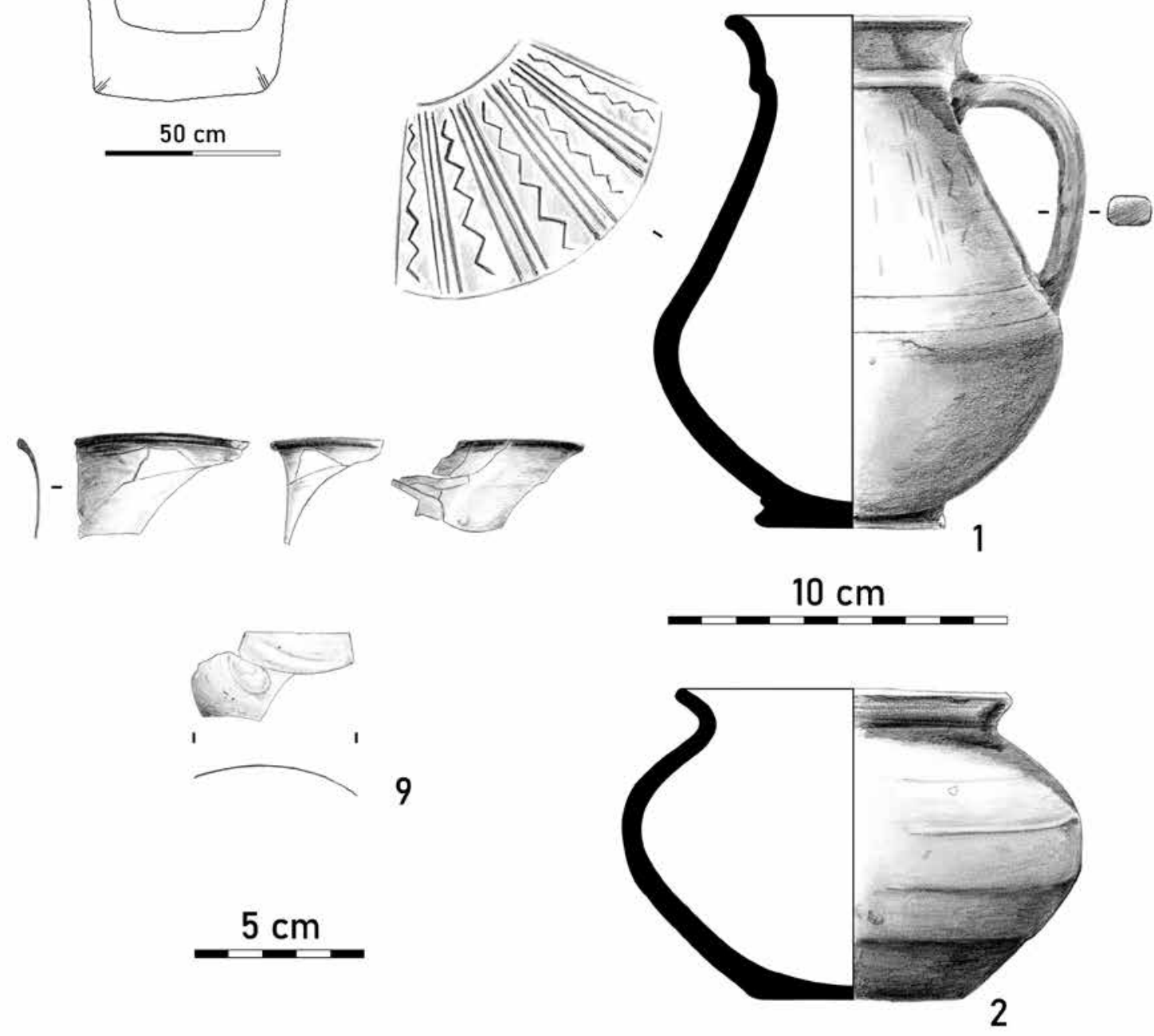

10. kép. M3-58. lelőhely: 6 . sír

Fig. 10. Site M3-58: Grave 6 
átm.: 10,2 cm; legnagyobb átm.: 13,4 cm; alj átm.: $6,5 \mathrm{~cm}$ (25. kép 1). 3. Masszív rézötvözet csat a két edény mellett. Az öntött keret ovális, egyik oldalán erőteljesen megvastagodik, a csattest vastag lemezből készült, lapos dobozszerűen kialakított széles peremmel, a csatkarikán áthajlított szíjszorító nyúlvánnyal, 3 felerősítő szegeccsel. A csat teljes h.: 3,3 cm; csatkarika h.: 2,9 cm, sz.: 1,6 cm. A csattest h.: 2,3 cm, sz.: 1,5 cm (19. kép 3). 4. Csüngődíszek: a) kis, rézötvözet-lemezből készített csengő. Akasztófüle a kónikus lemez felső végén áthúzott kettős drótból készült. H.: 1,5 cm; átm.: $1,1 \mathrm{~cm}$, lemez v.: 0,4 mm. b) Félhold alakú bronz(?)csüngő töredékek, $3 \mathrm{db}$, két csüngőhöz tartoznak. Rácsmintával díszített lapos öntvények. Eredetileg kb. $3 \mathrm{~cm}$ szélesek lehettek. V.: 1-1,3 mm. 5. Sötétkék, lapított gömb alakú üveggyöngy a sírgödör déli részén. $H .: 1,05 \mathrm{~cm}$; átm.: $1,35 \mathrm{~cm}$; furat átm.: $0,5 \mathrm{~cm}$. 6. Félkörös rugólemezű, rombuszos tűlemezü, ékvéséses kengyelfibula a sírgödör közepén. Rézötvözetből öntött, aranyozott, félkörös részén ellentett helyzetű spirálindamotívum és három gombdísz, rombikus részén koncentrikus rombuszalakzatok díszítik. Kengyele ívelt, domború, közepén borda fut végig. A tülemez szélét poncolt pontsor díszíti. A fibula „lába” halfarok-szerüen kiszélesedik, ennek az egyik szára letörött. Tüszerkezete hiányzik, csak a tütartó lemez és a tüszerkezet két kapcsolódó pontja maradt meg. H.: $5,83 \mathrm{~cm}$; rugólemez sz.: $2,75 \mathrm{~cm}$; tülemez sz:: 1,3 cm, v.: 0,1 cm (18. kép). 7. Lapított gömb alakú, áttetsző, színtelen üveggyöngy, a fibula alól került elő. H.: $0,78 \mathrm{~cm}$; átm.: 1,56 cm; furat átm.: $0,5 \mathrm{~cm}$ (17. kép 1). 8. Barnásfekete, gömbölyű üveggyöngy a sírgödör déli részén. H.: $1,25 \mathrm{~cm}$; átm.: $1,4 \mathrm{~cm}$; furat átm.: $0,5 \mathrm{~cm}$. 9. Kék, vékonyfalú, közepesen kihajló, melegen legömbölyített peremü, féltojás alakú üvegpohár töredékei a sírgödör nyugati részén, az 1-2. számú agyagedények körül elszórtan. Néhány töredék összeilleszthető. Összesen 5 perem és 46 oldaltöredék (köztük egészen aprók is), a rajzon csak néhány töredék szerepel, a fotó teljes. V.: 0,04 cm; perem v.: 0,25 cm; perem átm.: kb. $7 \mathrm{~cm}$ lehetett (22. kép).

7. sír (70/78) (11. kép).

Tájolás: Ny-K. Téglalap alakú, bolygatott sír. H.: $153 \mathrm{~cm}$; sz.: $63 \mathrm{~cm}$; m.: $83 \mathrm{~cm}$. A koponya sérült, mellette nem anatómiai rendben egy csigolya és egy kulcscsont volt, a gödör közepén pedig hosszúcsont töredékek feküdtek. A lábak csontjai nagyjából anatómiai rendben helyezkedtek el, amelyeket a térdnél egy állatjárat bolygatott.

Életkor és nem: a csontok nincsenek meg, az ásatáson tett megfigyelések alapján kisgyermek.

Mellékletek: 1 . Amorf vastárgy a sírgödör keleti végében 2. Ovális vascsat a jobb combcsont felett. H.: $4,1 \mathrm{~cm}$, sz.: $3,2 \mathrm{~cm}$; v.: $0,5 \mathrm{~cm}$; csattüske h.: $3,2 \mathrm{~cm}$. 3 . Vaskés töredéke az előző melléklettel együtt. Egyenes hátú, felső nyélállású. H.: $9 \mathrm{~cm}, \mathrm{sz} .: 1,9 \mathrm{~cm}$.

8. sír (72/80) (9. kép).

Tájolás: $\mathrm{Ny}-\mathrm{K}$. Téglalap alakú, erősen bolygatott sír. H.: $210 \mathrm{~cm}$; sz.: $58 \mathrm{~cm}$; m.: $24 \mathrm{~cm}$. A csontváz nagy része a sírgödör közepén koncentrálódott, de kisebb-nagyobb csontok az egész gödörben megfigyelhetőek vol- tak. Csigolyák, bordák, a két lapocka és a felkarcsontok maradtak meg.

Életkor és nem: 20-50 éves férfi.

Melléklete nem volt.

9. sír (73/81) (11. kép).

Tájolás: Ny-K. Téglalap alakú, bolygatott sír. H.: $166 \mathrm{~cm}$; sz.: $48 \mathrm{~cm}$; m.: $53 \mathrm{~cm}$. A bolygatási gödör jól megfigyelhető volt. Erősen bolygatott gyerekcsontváz, egy csontja sem volt az eredeti helyén. A koponya a sírgödör közepén helyezkedett el. Ettől keletre volt található néhány borda és csigolya, illetve a medence egy darabja. A sír keleti felében további bordák és lábszár-, valamint combcsontok feküdtek.

Életkor és nem: 3-4 éves gyermek.

Mellékletek: 1. Fazék peremtöredéke a betöltésből. Szitált köves soványítású, gyorskorongolt, rövid, fedőhornyos peremü, erősen ívelt hasú kisfazék töredéke. Perem átm.: $8,5 \mathrm{~cm}$; oldal v.: $0,35 \mathrm{~cm}$. A bolygatott részről három állatcsont is előkerült: Bárány Annamária meghatározása szerint egy szarvasmarha lábujjperc, egy kiskérődző tibia és egy teknős.

10. sír (95/115).

Tájolás: DNy-ÉK. Téglalap alakú, bolygatott sír. H.: $166 \mathrm{~cm}$; sz.: $70 \mathrm{~cm}$; m.: $86 \mathrm{~cm}$. A sír betöltéséből szétszórva csontok kerültek elö, semmi sem feküdt eredeti helyzetében. Sírrajz nincs.

Az embercsontok nincsenek meg.

Mellékletek: A sír betöltésből egy darabokra esett vastárgytöredék került elö.

11. sír (71/224) (9. kép).

Tájolás: NyÉNy-KDK. Téglalap alakú, erősen bolygatott sír. H.: 180 cm, sz.: 64 cm; m.: $83 \mathrm{~cm}$. Csak a lábszár- és a lábtőcsontok egy része maradt meg. A sírt ráásták egy bronzkori gödörre, az összesítő térkép alapján pedig a 17. sír (184/249) metszette ezt a temetkezést. ${ }^{33}$

Életkor és nem: 20 évesnél idősebb, ismeretlen nemü egyén.

Melléklete nem volt.

12. sír (61/225) (12. kép).

Tájolás: NyÉNy-KDK. Téglalap alakú, bolygatatlan sír, amelyet ráástak egy bronzkori gödörre. H.: $180 \mathrm{~cm}$; sz.: $40 \mathrm{~cm}$; m.: $60 \mathrm{~cm}$. Nyújtott vázas temetkezés, karok a test mellett, lábszárcsontok keresztben. A lábfejet és kézcsontokat kivéve a váz épségben volt, a fej balra fordult. Vázhossz: $152 \mathrm{~cm}$. A bordák egy részét valószínüleg állatjárat bolygatta meg.

A csontok nincsenek meg.

Melléklete nem volt.

13. sír (174/234).

Tájolás: $\mathrm{Ny}-\mathrm{K}$. Téglalap alakú sírgödör, erösen bolygatott. H.: $165 \mathrm{~cm}$; sz.: $72 \mathrm{~cm}$; m.: $74 \mathrm{~cm}$. A váz csaknem teljesen hiányzik, a betöltésből a koponyacsont egy darabja került csak elö. Sírrajz nincs.

Életkor és nem: 14 évnél fiatalabb egyén koponyatöredéke. Melléklete nem volt.

\footnotetext{
${ }^{33}$ Erről a helyzetről egyéb információval nem rendelkezünk.
} 
14. sír (175/235) (13. kép).

Tájolás: Ny-K. Téglalap alakú, bolygatott sír. H.: $190 \mathrm{~cm}$; sz.: $76 \mathrm{~cm} ; \mathrm{m} .: 63 \mathrm{~cm}$. A csontváz erösen bolygatott, hiányos. A csontok nagy része a sírgödör nyugati felében feküdt. A koponya és a hosszúcsontok többsége hiányzik. Életkor és nem: a csontok nincsenek meg, az ásatási megfigyelések alapján idősebb gyermek.

Mellékletek: 1. Csüngődísz karikára hajlított, a két végén egymásra csavart ezüstdrótból, zöld, hengeres üveggyöngy díszítéssel, a sír délnyugati sarkában. Átm.: $2,2 \mathrm{~cm}$, v.: $0,1 \mathrm{~cm}$. Gyöngy, h.: $0,36 \mathrm{~cm}$, átm.: $0,5 \mathrm{~cm}$ (17. kép 6). 2. Üvegtöredékek az előző melléklettől északra, $10 \mathrm{~cm}$-re: olívazöld, vékonyfalú üvegpohár kisebb töredékei, két megvastagodó, melegen lekerekített perem (a rajzos táblán csak ezek szerepelnek, a fotó teljes) és hét oldaltöredék (ezekböl három, illetve kettő összeillesztve). Három oldaltöredéken díszítés látszik: plasztikus borda, alatta két helyen kis formába nyomott, hosszúkás, ovális/csepp alakú minta. V.: $0,06 \mathrm{~cm}$, perem v.: $0,31 \mathrm{~cm}$ (23. kép). (Két mellékletként került elcsomagolásra, a 2. sz. a bontás során, a 32. sz. valószínüleg ennek közelében, a sír felszedése során jött elö.) 3. Millefiori üveggyöngy a sír nyugati oldalánál, az előző melléklettől északra, $10 \mathrm{~cm}$-re. Szétesett, kék alapszínű volt piros mintával. 4. Hordó alakú üveggyöngy az előző melléklettől keletre, $7 \mathrm{~cm}$-re. Jól kivehetőek a gyöngyöt alkotó üvegszálak. H.: 0,6 cm; átm.: 0,65 cm; furat átm.: 0,3 cm (nincs rajz). 5. Az elözőhöz hasonló üveggyöngy attól délre, $10 \mathrm{~cm}$-re. H.: $0,55 \mathrm{~cm}$, átm.: $0,6 \mathrm{~cm}$, furat átm.: $0,25 \mathrm{~cm}$. 6. Nagyon apró zöld üveggyöngy az előzőtől délre, $6 \mathrm{~cm}$ re. Átm.: $0,27 \mathrm{~cm}$ (nincs rajz). 7. Vékony ezüstlemez hengeres, hosszúkás csonkakúp formára hajlítva, sakktábla elrendezésủ poncolt díszítéssel, az előbbi melléklettől keletre. A keskenyebb végéhez közelebb két kerek lyuk, eredetileg itt volt felfüggesztve, a felfüggesztő drót kis töredéke is megmaradt. H.: $4,2 \mathrm{~cm}$, átm. a keskenyebb részén $0,8 \mathrm{~cm}$, lemez v.: 0,1 mm. 8. Lapított gömb alakú, színtelen üveggyöngy az elözőtoől délre, $6 \mathrm{~cm}$-re. H.: $0,45 \mathrm{~cm}$; átm.: $1,05 \mathrm{~cm}$, furat átm.: $0,5 \mathrm{~cm}$. 9. Lapított gömb alakú, fekete alapszínű, eredetileg fehér, szabálytalan, szórt pötytyökkel díszített üveggyöngy a sír közepén, az előző melléklettől keletre. A pöttyök lekoptak, a felszín kopott. H.: $1,1 \mathrm{~cm}$; átm.: $1,5 \mathrm{~cm}$; furat átm.: $0,6 \mathrm{~cm}$. 10. Lapított gömb alakú, fekete alapon kék szemes üveggyöngy a 9. melléklethez közel. A gyöngynek csak az egyik oldalán van három kék pötty, ebből kettő elfolyt, illetve a pöttyöket kék üvegszálak kötik össze. H.: 0,62 cm; átm.: 0,95 cm, furat átm.: 0,4 cm (17. kép 3). 11. Az 1. sz. melléklethez hasonló csüngődísz karikára hajlított, a két végén egymásra csavart ezüstdrótból, két hengeres, fekete üvegygyönggyel felszerelve, a 9-10. melléklettől délre. Átm.: $1,7 \mathrm{~cm}$, v.: $0,1 \mathrm{~cm}$. Gyöngy h.: 0,33 és $0,35 \mathrm{~cm}$, átm.: 0,5 és $0,6 \mathrm{~cm}$ (17. kép 5). 12. Bikónikus, színtelen üveggyöngy, a gyöngyöt alkotó üvegszálak jól kivehetőek. Átm.: $1,37 \mathrm{~cm}, \mathrm{~m} .: 0,73 \mathrm{~cm}$, furat átm.: $0,5 \mathrm{~cm}$. 13. Lapított gömb alakú, színtelen üveggyöngy az elöző melléklettől keletre, $8 \mathrm{~cm}$-re. H.: $0,76 \mathrm{~cm}$, átm.: $1,5 \mathrm{~cm}$, furat átm.: $0,5 \mathrm{~cm}$. 14. Harang alakú fogólemezű csontfésủ tö- redéke került elő a temetkezés délnyugati sarkához közel, a megbolygatott csontok közül. H.: $6,2 \mathrm{~cm}$; sz.: $5,9 \mathrm{~cm}$; v.: $0,7 \mathrm{~cm}$. A két fogólemeze töredékes, a több darabból álló belső, fogazott részből három lemez maradt meg, a fogai egy szélső tag kivételével letörtek. A megmaradt lemezek hat darab rézszegeccsel vannak rögzítve. Mindkét fogólemezén vésett pont-kör sor húzódik a felső perem mentén (20. kép). A csontváz felszedése során további tárgyak kerültek elő: 15. korong alakú borostyángyöngy. Egyik oldala töredékes, felülete kopott, körben két vésett vonal. M.: $0,9 \mathrm{~cm}$, átm.: $1,65 \mathrm{~cm}$, furat átm.: $0,35 \mathrm{~cm}$. 16. Lapított gömb alakú, vízszínü üveggyöngy. H.: $0,82 \mathrm{~cm}$, átm.: $1,92 \mathrm{~cm}$, furat átm.: $0,45 \mathrm{~cm}$. 17. Kisméretü gyürű egymásra hajlított végü ezüstpántból, két vége kiszélesedik, az 1. számú melléklet alól került elö. A pereme mentén végig bekarcolás. Átm.: $1,6 \mathrm{~cm}$, sz.: $0,4 \mathrm{~cm}$, v.: $0,05 \mathrm{~cm}$. 18. Lapított gömb alakú (majdnem hengeres), aszimmetrikus magasságú vörös üveggyöngy. H.: $0,8 \mathrm{~cm}$, átm.: $1,24 \mathrm{~cm}$, furat átm.: $0,4 \mathrm{~cm}$. 19. Lapított gömb alakú, vörös üveggyöngy. $H .: 0,82 \mathrm{~cm}$, átm.: $1,16 \mathrm{~cm}$, furat átm.: $0,5 \mathrm{~cm}$. 20. Hordó alakú, aszimmetrikus magasságú millefiori üveggyöngy, foltos zöld alapszínü, ellentett helyzetben két vöröses, négyszirmú virágot mintázó díszítéssel. H.: $1,19 \mathrm{~cm}$, átm.: $1,3 \mathrm{~cm}$, furat átm.: 0,5 cm (17. kép 4). 21. Római ezüstpénz, Marcus Aurelius denar, erősen kopott, a 4. melléklet közeléből. 22. Az 1. és 11. sz. melléklethez hasonló csüngődísz karikára hajlított, a két végén egymásra csavart ezüstdrótból, fekete üveggyöngyökkel felszerelve. Átm.: $1,8 \mathrm{~cm}$, v.: $0,1 \mathrm{~cm}$; gyöngyök h.: 0,26 és $0,3 \mathrm{~cm}$, átm.: 0,5 és $0,44 \mathrm{~cm}$ (17. kép 7). 23. Hatszögletü hasáb alakú, kopott, zöld üveggyöngy. $\mathrm{H} .: 1,13 \mathrm{~cm}$, átm.: $0,47 \mathrm{~cm}$, furat átm.: $0,25 \mathrm{~cm}$. 24. Korong alakú borostyángyöngy, oldalán az egyik peremhez közel körbefutó, vésett vonallal díszítve. H.: $0,62 \mathrm{~cm}$, átm.: $1,25 \mathrm{~cm}$, furat átm.: $0,45 \mathrm{~cm}$. 25 . Nagyon apró, lapított gömb alakú zöld üveggyöngy (nincs rajz). H.: $0,14 \mathrm{~cm}$, átm.: $0,25 \mathrm{~cm}$, furat átm.: $0,1 \mathrm{~cm}$. 26 . Lapított gömb alakú, aszimmetrikus magasságú, kék üveggyöngy. H.: $0,85 \mathrm{~cm}$, átm.: $1,2 \mathrm{~cm}$, furat átm.: $0,42 \mathrm{~cm}$. 27. Barnásvörös színü, aszimmetrikus hengeres üveggyöngy, szabálytalan, fehér folyatott hullámvonal dísszel. H.: 0,61$1,05 \mathrm{~cm}$, átm.: $1,26 \mathrm{~cm}$, furat átm.: $0,5 \mathrm{~cm}$ (17. kép 2). 28. Lapított gömb alakú (majdnem hengeres) borostyángyöngy. H.: $0,63 \mathrm{~cm}$, átm.: $1,13 \mathrm{~cm}$, furat átm.: $0,4 \mathrm{~cm}$. 29. Lapított gömb alakú, kék üveggyöngy. $H .: 0,86 \mathrm{~cm}$, átm.: $1,15 \mathrm{~cm}$, furat átm.: $0,6 \mathrm{~cm}$. 30 . Töredékes, két helyen átfúrt római ezüstpénz, III. Valentinianus siliqua. 31. Apró fémlemez (ezüst vagy rézötvözet) töredék.

15. sír (177/237) (12. kép).

Tájolás: $\mathrm{Ny}-\mathrm{K}$. Téglalap alakú, a sarkainál lekerekített sírgödör. H.: $198 \mathrm{~cm}$; sz.: $54 \mathrm{~cm}$; m.: $47 \mathrm{~cm}$. A csontváz erösen bolygatott, a csontok legnagyobb részét a sírgödör nyugati részébe tolták félre, a koponya és a medencecsont hiányzik. A láb hosszúcsontjai a sír déli oldalánál helyezkedtek el. A sírgödör keleti végében, eredeti helyükön feküdtek a lábfej csontjai.

Életkor és nem: 30-50 éves férfi.

Melléklete nem volt. 


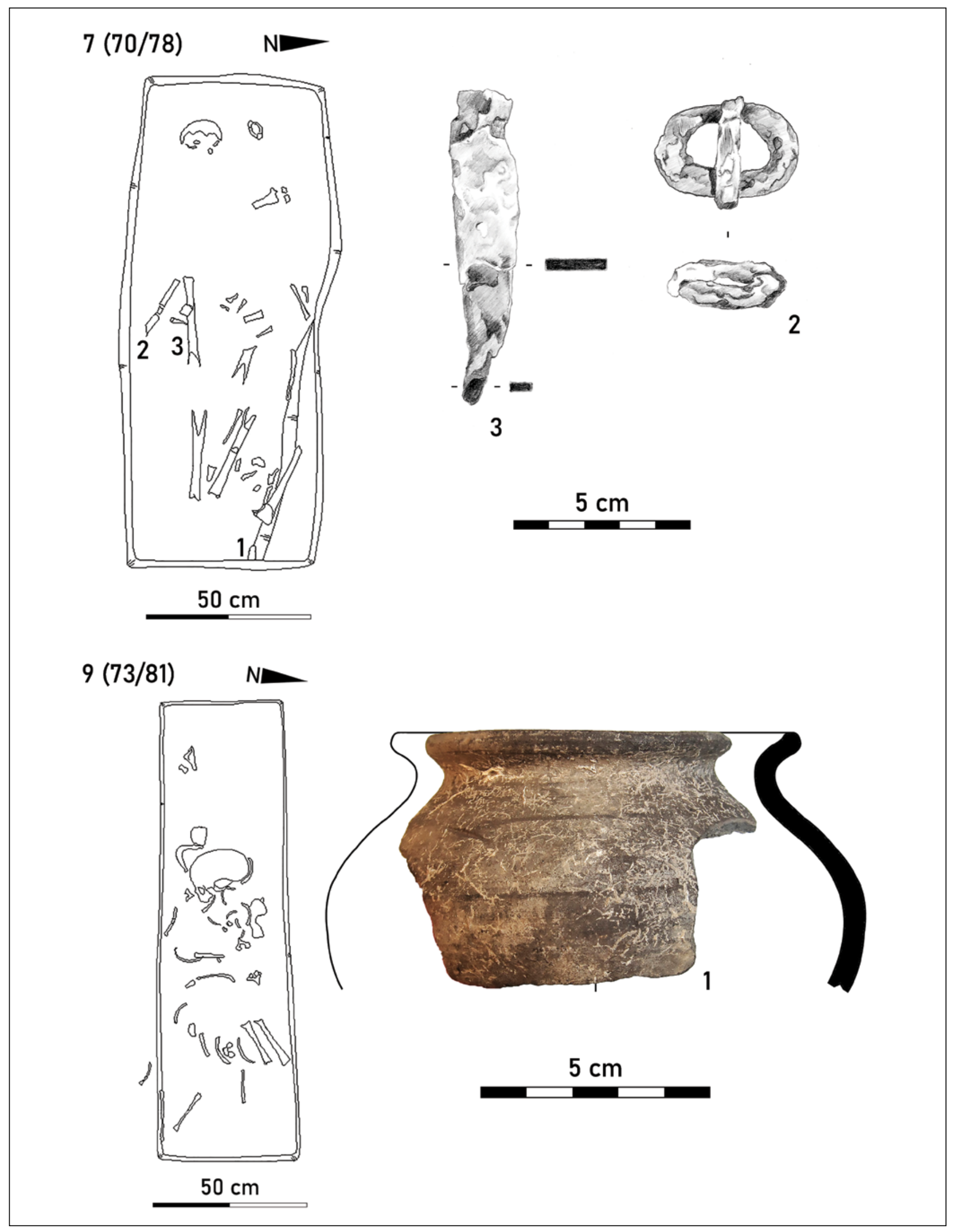

11. kép. M3-58. lelőhely: 7., 9. sír

Fig. 11. Site M3-58: Grave 7, 9 

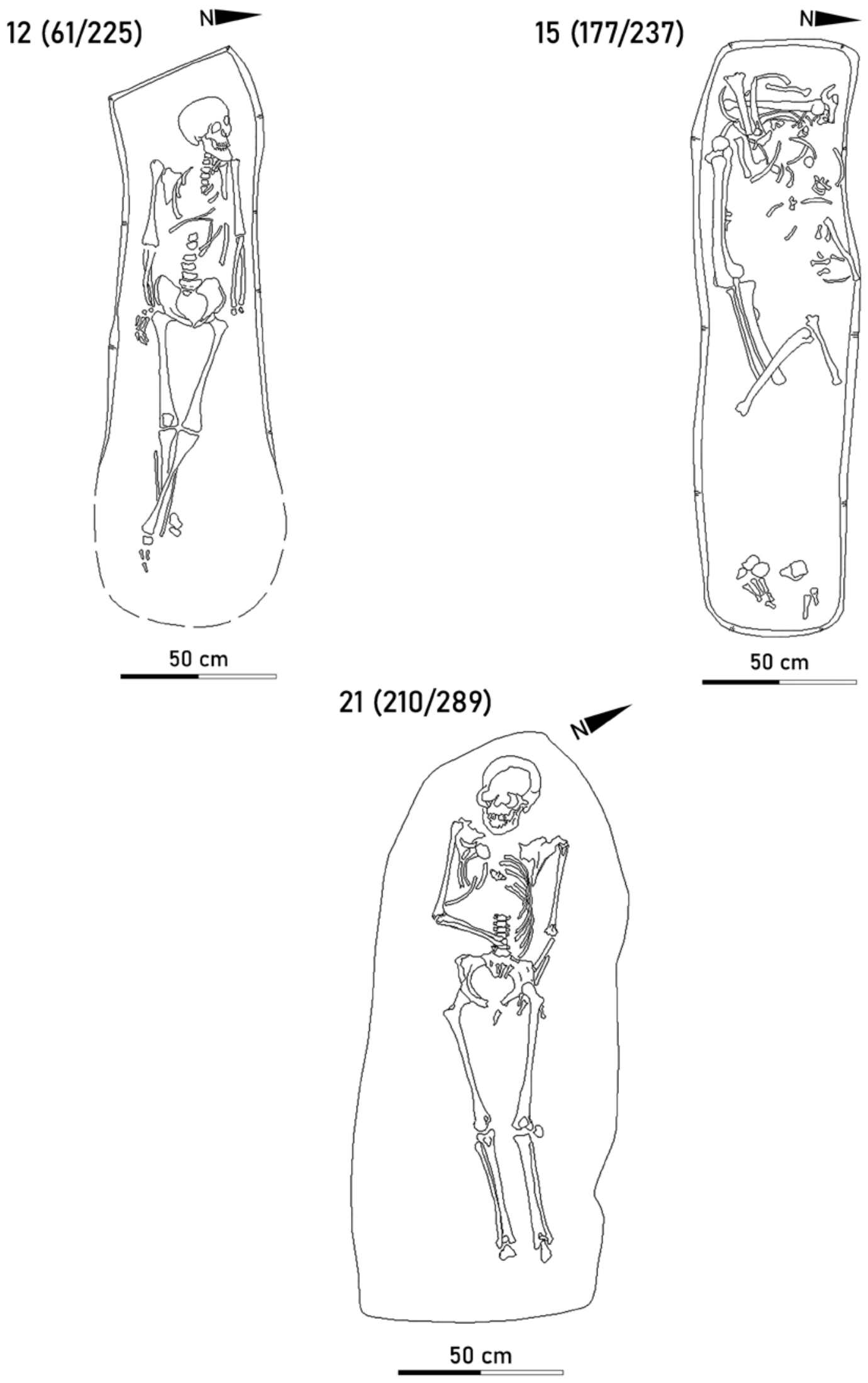

12. kép. M3-58. lelőhely: 12., 15., 21. sír

Fig. 12. Site M3-58: Grave 12, 15, 21 
16. sír (182/247) (14. kép)

Tájolás: $\mathrm{Ny}-\mathrm{K}$. Téglalap alakú sír, északnyugati részét ívelten kiszélesítette a bolygatási gödör. H.: $174 \mathrm{~cm}$; sz.: $72 \mathrm{~cm} ; \mathrm{m} .: 70 \mathrm{~cm}$. Alja állatjárat miatt szabálytalan. A csontváz erősen bolygatott, a csontok nagy része a sírgödör északnyugati részében feküdt, csak a medence egy része, egy hosszúcsont és néhány fog maradt meg.

A csontok nincsenek meg.

Mellékletek: 1. Lapított gömb alakú, fehér üveggyöngy a sírgödör délnyugati sarkában. H.: $0,64 \mathrm{~cm}$, átm.: $0,86 \mathrm{~cm}$, furat átm.: $0,35 \mathrm{~cm}$. 2. Lapított félgömb alakú borostyángyöngy az előzőtől keletre, $23 \mathrm{~cm}$-re. H.: $0,97 \mathrm{~cm}$, átm.: $1,7 \mathrm{~cm}$, furat átm.: $0,5 \mathrm{~cm}$. 3. Kisméretü, lapított gömb alakú, gerezdelt (bordázott pántból hajlított), sötétszürke fémgyöngy, valószínüleg ezüst, az előző melléklettől jobbra, $15 \mathrm{~cm}$-re. H.: $0,4 \mathrm{~cm}$, átm.: $0,52 \mathrm{~cm}$, furat átm.: $0,35 \mathrm{~cm}$. 4. Az elöbbihez hasonló, kisméretü gyöngy, attól északra. H.: $0,4 \mathrm{~cm}$, átm.: $0,45 \mathrm{~cm}$, furat átm.: $0,2 \mathrm{~cm}$. 5. Az elöbbiekhez hasonló, kisméretű gyöngy a 4. számú melléklettől közvetlenül északra. H.: $0,4 \mathrm{~cm}$, átm.: $0,54 \mathrm{~cm}$, furat átm.: $0,3 \mathrm{~cm}$. Ezzel együtt egy nagyon apró, $0,23 \mathrm{~cm}$ átmérőjü gömbölyü gyöngy. 6 . Az előbbiekhez hasonló, kisméretü gyöngy az előző melléklettől keletre. H.: $0,4 \mathrm{~cm}$, átm.: $0,5 \mathrm{~cm}$, furat átm.: $0,25 \mathrm{~cm}$. 7 . Hasáb alakú, bordó üveggyöngy a 3-6. sz. mellékletektől $5 \mathrm{~cm}$ re, északkeletre. H.: 0,62 cm, átm.: 0,58 cm, furat átm.: $0,25 \mathrm{~cm}$. 8. Lapított gömb alakú, piros üveggyöngy az elöző melléklettől keletre, $24 \mathrm{~cm}$-re. H.: 0,65 cm, átm.: $0,9 \mathrm{~cm}$, furat átm.: $0,35 \mathrm{~cm}$. 9. Lapított gömb alakú, fehér üveggyöngy ettől délkeletre, $15 \mathrm{~cm}$-re. H.: 0,56 cm, átm.: $0,76 \mathrm{~cm}$, furat átm.: $0,3 \mathrm{~cm}$. 10. Lecsapott sarkú hasáb alakú, törött, kék üveggyöngy a 9. melléklettől ÉK-re, $11 \mathrm{~cm}$-re. H.: $0,75 \mathrm{~cm}$, sz.: $0,55 \mathrm{~cm}$, furat átm.: $0,28 \mathrm{~cm}$. 11. Bikonikus, szürke agyag orsógomb az előző lelettől DK-re, $8 \mathrm{~cm}$-re. M.: $1,5 \mathrm{~cm}$, átm.: $3,6 \mathrm{~cm}$, furat átm.: $0,9 \mathrm{~cm}$. 12. Szabálytalan peremü és felszínü, korong alakú borostyángyöngy, furata aszimmetrikusan helyezkedik el. A bontás során, a betöltésből jött elő. M.: $0,5 \mathrm{~cm}$, átm.: $1,5 \mathrm{~cm}$, furat átm.: $0,4 \mathrm{~cm}$. 13. Sötétkék, gömbölyü üveggyöngy a 7. melléklettől délre, $4 \mathrm{~cm}$-re. $H .: 0,75 \mathrm{~cm}$, átm.: $0,78 \mathrm{~cm}$, furat átm.: $0,3 \mathrm{~cm}$. A restaurálás során két nagyon apró, $2,2 \mathrm{~mm}$ átmérőjü, gömbölyü fekete gyöngy került elő a furatból, hasonlóak az 5. sz. gyönggyel együtt találthoz (ezekről nem készült rajz).

17. sír (184/249) (14. kép).

Tájolás: Ny-K. Téglalap alakú sírgödör. $H .: 210 \mathrm{~cm}$; sz.: $60 \mathrm{~cm} ; \mathrm{m} .: 50 \mathrm{~cm}$. A csontváz részlegesen volt bolygatott, nyújtott helyzetben a hátán feküdt. A bordák és a gerinccsigolyák egy része a koponya mellett, a sírgödör délnyugati részében helyezkedett el. Vázhosszúság: $180 \mathrm{~cm}$.

A csontok nincsenek meg.

Mellékletek: 1. Vasfibula a jobb felkar alatt, a váz felszedése során jött elő. Egytagú, alsóhúros, oldalt hajtott lábú fibula, kengyele ívelt, négyszögletes átmetszetü. Erösen korrodált, a tű vége letörött. $H .: 6,8 \mathrm{~cm}$, a rugó sz.: $1,5 \mathrm{~cm}$. 2. Vascsat, a felszedés során a jobb váll környékén jelentkezett. H.: $4 \mathrm{~cm}$, sz.: $2,65 \mathrm{~cm}$, v.: $0,4 \mathrm{~cm}$, csattüske h.: $2,7 \mathrm{~cm}$. 3. Meghajlított vaslemez (nyélborítás? tok?), a sír délnyugati sarkában került elő. $\mathrm{H} .: 2,4 \mathrm{~cm}$, sz.: $2,5 \mathrm{~cm}$, v.: $1,15 \mathrm{~cm}$, lemez v.: $0,2 \mathrm{~cm}$. A betöltésböl pattintott kő. M.: $2,5 \times 2,4 \times 1,6 \mathrm{~cm}$ (nincs rajz).

18. sír (63/70) (15. kép).

Tájolás: Ny-K (?) Nyújtott, lekerekített végü sírgödör. H.: $184 \mathrm{~cm}$; sz.: $40 \mathrm{~cm}$; m.: $61 \mathrm{~cm}$. A sír mellett közvetlenül, néhány cm-re a 19. (63/253) temetkezés feküdt. A sírfoltok egy nagy, közös foltban jelentkeztek, azonban az alsóbb rétegekben elváltak. ${ }^{34} \mathrm{~A}$ csontváz bolygatott volt, rossz megtartású, csupán kevés csonttöredék maradt meg.

Életkor és nem: 20-60 éves egyén.

Mellékletek: 1. Vékony falú, olívazöld üvegpohár-töredékek kerültek elő a sírgödörben, a sír nyugati vége és a közepe között szétszóródva. Hét darab, részben összeillő oldaltöredék, hosszúkás rátétdíszekkel, a 19. sírhoz elcsomagolt pohártöredékekkel alkothat egy egységet (falának v.: $0,5-0,8 \mathrm{~mm}$ ) (24. kép 2). E darabok talán az ugyanebből a sírból előkerült harang alakú pohár részei: 2 . a többi töredék egy melegen lekerekített, ívelt peremü, harang alakú testü, rátétes díszű olívazöld üvegpohárhoz tartozik. Összesen két perem és öt oldaltöredék, összeilleszthetők. Perem v.: $0,33 \mathrm{~cm}$, oldal v.: $0,8 \mathrm{~mm}$. Perem átm.: kb. $8 \mathrm{~cm}$ (24. kép 1). (Nem készült rajz valamennyi üvegtöredékről, a fotó teljes.) A fentieken kívül egy kis, átlátszatlan, sötétkék, rátétdíszes üvegtöredék is előkerült ebből a sírból, helyzete ismeretlen.

19. sír $(63 / 253)$ (15. kép).

Tájolás: Ny-K. Nyújtott, lekerekített sarkú sírgödör. H.: $182 \mathrm{~cm}$; sz.: $35 \mathrm{~cm}$; m.: $61 \mathrm{~cm}$. Háton fekvő, nyújtott helyzetű, részlegesen bolygatott temetkezés. Váz h.: $175 \mathrm{~cm}$. A mellkas és a koponya nem volt eredeti helyén, a lábak valószínüleg igen. A karcsontok a sír déli részére voltak tolva.

A csontok nincsenek meg.

Melléklet: 1. Üvegedény töredékei kerültek elő a sírban középtájon, az északi falnál, valószínüleg a 18. sír poharához tartoznak. Vékonyfalú, olívazöld üvegpohár oldaltöredékei rátétes bordadíszekkel. Nyolc darab, kettő öszszeillik. Old. v.: 0,5-0,6 mm. (Nem készült az összes töredékről rajz, a fotó - 24. kép 3 - teljes.)

20. sír (187/254) (15. kép).

Tájolás: Ny-K. Téglalap alakú sírgödör, a temetkezés oldala az északi és a déli részen egy-egy rövid szakaszon ívelten kiszélesedik. H.: $220 \mathrm{~cm}$; sz.: $78 \mathrm{~cm}$;.$: 52 \mathrm{~cm}$. A csontváz erősen bolygatott volt, a csontok közül valószínúleg csak a koponya maradt a helyén, a hosszúcsontok a sírgödör közepén és a keleti végében voltak szétszórva. A bordák, a csigolyák és a kisebb csontok hiányoztak.

A csontok nincsenek meg.

Mellékletek: 1. Vas csattüske töredéke a betöltésböl. H.: $2,5 \mathrm{~cm}$. Pattintott kő a sír betöltéséből. M.: 2,75×1,8× $1,1 \mathrm{~cm}$ (nincs rajz.)

${ }^{34} \mathrm{~A}$ sírfotók alapján a 18 . és a 19. sír valóban két, egymáshoz nagyon közel fekvő temetkezés és nem egy nagyobb sírgödör. Ezt a kérdést az antropológiai adatokkal tudnánk ellenőrizni, azonban a 19. sírból származó embercsontok nincsenek meg. 
21. sír (210/289) (12. kép).

Tájolás: NyDNy-KÉK. A sírgödör nyugati vége lekerekített. H.: $178 \mathrm{~cm}$; sz.: $77 \mathrm{~cm}$; m.: $15 \mathrm{~cm}$. A sír bolygatása recens, részleges. A csontváz nyújtott helyzetben a hátán feküdt, a koponya a humuszolás során megsérült. Váz h.: $157 \mathrm{~cm}$. A lábszárak és a bal kar nyújtott helyzetben feküdt, a jobb alkar behajlítva a medencecsonton helyezkedett el. A jobb oldali bordák nem anatómiai rendben feküdtek. A lábujjcsontok hiányoznak.

Életkor és nem: 20-25 éves nő.

Melléklete nem volt.

Bizonytalan temetkezések:

22. sír (178/238).

Tájolás: Ny-K. Téglalap alakú gödör. H.: $195 \mathrm{~cm}$; sz.: $80 \mathrm{~cm} ; \mathrm{m} .: 74 \mathrm{~cm}$. A gödörből csontok és mellékletek nem kerültek elö. ${ }^{35}$

23. sír (179/239).

Tájolás: Ny-K. Téglalap alakú gödör. H.: 197 cm; sz.: $82 \mathrm{~cm}$; m.: $74 \mathrm{~cm}$. A gödörből csontok és mellékletek nem kerültek elö.

24. sír (180/240).

Tájolás: Ny-K. Téglalap alakú gödör. H.: $190 \mathrm{~cm}$; sz.: $70 \mathrm{~cm} ; \mathrm{m} .: 74 \mathrm{~cm}$. A gödörből csontok és mellékletek nem kerültek elö.

Szórványtárgyak (15. kép):

126. strat. Bronz huzalkarperec töredéke. $H .: 6,2 \mathrm{~cm}$, v.: $0,65 \mathrm{~cm}$.

171. strat. Vese alakú övcsat, csatkarikára hajló pecekkel. A csattüske töve téglalap alakúra van kialakítva. H.: $4,05 \mathrm{~cm}, \mathrm{sz} .: 2,4 \mathrm{~cm}$, v.: $0,5 \mathrm{~cm}$.

\section{Temetkezési szokások, sírbolygatás}

A temetö szerkezete, tájolás, sírmélység és sirforma. A nyíregyházi temető 21 (a bizonytalan funkciójú objektumokkal együtt 24) temetkezésével a korszak nagyobb sírszámú temetői közé tartozik a térségben. ${ }^{36}$ Ezen kívül három egykorú vagy közel egykorú, 5. és 5-6. századi temetőről-temetőrészletről van tudomásunk a környékről, amelyeket Kótajon (10 sír), ${ }^{37}$ Nyíregyháza-Oroson (8 sír $)^{38}$ és Nyíregyháza-Rozsrétszőlőn (34 sír) ${ }^{39}$ tártak fel. E temetkezőhelyek jól elkülöníthetőek temetkezési szokásaik és leletanyaguk alapján a késő szarmata-hun kori sírmezőktől, amelyek szintén megtalálha-

\footnotetext{
${ }^{35}$ Ezekről az objektumokról rajz nem áll a rendelkezésünkre.

${ }^{36}$ Vö. KIss 2017.

${ }^{37}$ Kótaj-Verba tanya (Jósa András Múzeum, Régészeti Adattár [JAM RégAd]: 2007.56). E témakörben összefoglaló előadást tartott Istvánovits Eszter a 2015. december 14-15-én az ELTE Régészettudományi Intézetében rendezett konferencián („Kollaps - Neuordnung - Kontinuitäten. Das Theissgebiet nach dem Untergang des Hunnenreiches." Internationale Tagung).

${ }^{38}$ Nyíregyháza-Oros, Úr-Csere (M3 keleti elkerülő 26. lelőhely): Marta et al. 2005a.

${ }^{39}$ Csaknem teljesen feltárt 5. századi temető: Nyíregyháza-Rozsrétszőlő, Nevelős-homokbányától D-re (Varga-tábla): ALmássy et al. 2006 .
}

tóak Nyíregyháza környékén az utóbbi évtizedek nagyfelületű feltárásainak köszönhetően (16. kép). ${ }^{40}$ Ezeken kívül a régióból több hun kori, többnyire É-D-i tájolású „magányos” temetkezés is ismert, amelyek részben a fent említett késő szarmata-hun kori, illetve 5. századi temetők közelében kerültek elö. ${ }^{41} \mathrm{~A}$ különböző típusú temetkezőhelyeknek a kronológiai viszonya, valamint társadalmi és etnikai értelmezése csak az újabb leletanyagok minél nagyobb mértékủ publikálása után válik lehetővé. ${ }^{42}$

Ha az időrend kérdését a gepida kori soros temetők felöl közelítjük meg, akkor azt mondhatjuk, hogy a nyíregyházi M3-58. lelőhelyen feltárt temetőt - mint majd látni fogjuk valamivel korábban alapíthatták, mint azokat, és használati ideje is jóval rövidebb időt ölel fel.

A sírok a temetőben egymáshoz közel, nagyjából három, észak-déli irányú sorban helyezkedtek el. A sírgödröket egységesen NY-K-i irányban tájolták, ami az 5. század második felétől szinte kizárólagossá vált a Kárpát-medencében. ${ }^{43}$ Ettől csak öt sírnál volt tapasztalható némi eltérés: kettő $\mathrm{NyDNy}-$ KÉK, három NyÉNy-KDK irányban feküdt.

\footnotetext{
${ }^{40}$ Hivatkozások a 16. képen feltüntetett lelőhelyekhez. 1: Nyíregyháza, Nyulas-tói-csatornától D-re (JAM RégAd: 2021.222); 2: Kótaj, Verba-tanya, Halastó (Pintye Gábor információja); 3: Nyíregyháza-Stadion (CsalláNy 1958); 4: Nyíregyháza, Mandabokor II. (nyugati elkerülő 36. lh.) (JAM RégAd: 2014.67-68.); 5: Nyíregyháza, Szelkó-dűlő (M3-148/b lelőhely) és Nyíregyháza-Rozsrétszőlő, Szelkó-dűlő, Rozsréti kaszáló (M3-214. és M3-215. lelőhely) (Pintye 2014); 6: Nyíregyháza, Császárszállás-Varga tábla (M3-182. lelőhely) és Nyíregyháza, Ipari Park IV. (Marso telephely) (PinTye 2018b); 7: Nyíregyháza Rozsrétszőlő, Nevelős homokbányától D-re (Császárszállás, Varga tábla III., M3-36/c lelőhely) (Almássy et al. 2006a); 8: Nyíregyháza-Császárszállás, Vasútállomástól Ny-ra (Butyka, M3-137. lelőhely) (Almássy et al. 2006b); 9: Nyíregyháza-Oros, Kánya-hegy-dülő (Üzleti Megapark 44. lelőhely) (Istvánovits 2012); 10: Nyíregyháza, Úr Csere Észak (Oros, M3 keleti elkerülő 27. lelőhely) (Gindele et al. 2005); 11: Nyíregyháza, Úr Csere (Oros, M3 keleti elkerülő 26. lelőhely) (MARTA et al. 2005a); 12: Nyíregyháza, Úr Cserétől D-re (M3 keleti elkerülő 33. lelőhely) (IsTvÁNovits-Kulcsár 2014); 13: Nyíregyháza, Lévai-tag (M3 keleti elkerülő 53. lelőhely) (MArTA et al. 2005b); 14: Nyíregyháza, Csorda-Páskum II. (M358. lelőhely); 15: Nyíregyháza, Csorda-Páskum I. (M3-14. lelöhely) (PinTye 2016); 16: Nagykálló, Kis-Ludastó-dűlő (JAM RégAd: 2010.115; Pintye 2018a).

${ }^{41}$ Pl. Nyíregyháza-Rozsrétszőlő (PINTye 2014); Nagykálló-KisLudastó-dülő (Pintye 2018a).

${ }^{42} \mathrm{Az}$ 5. századra jellemző kis sírszámú temetkezőhelyekről és magányos sírokról összefoglalóan ld. KIss 2017, ezen kívül pl. NAGY 1993, 60; Rácz 2014, 205. A jelenséget többféleképpen magyarázták, a hun kor folyamán bekövetkezett népességcsökkenéssel, a korszakban tapasztalható nagyfokú mobilitással, a településszerkezet megváltozásával és a kisebb települési egységek, tanyák megjelenésével, a gazdag hun kori magányos sírok esetén pedig az elit szeparációra való törekvésével is. Az is felmerült a kutatásban, hogy egyes területeken a hun korban is tovább élő helyi szarmata lakosság élére helyezett vezetők temetkezései e magányos sírok (pl. Nyíregyháza környékén: Pintye 2014, 131; Pintye 2018a, 293; Kecskemét környékén: Ny. Kovacsóczy et al. 2021).

${ }^{43}$ Nagy 1993, 60; B. Тóth 1994, 287; RÁcz 2016, 307-309.
} 

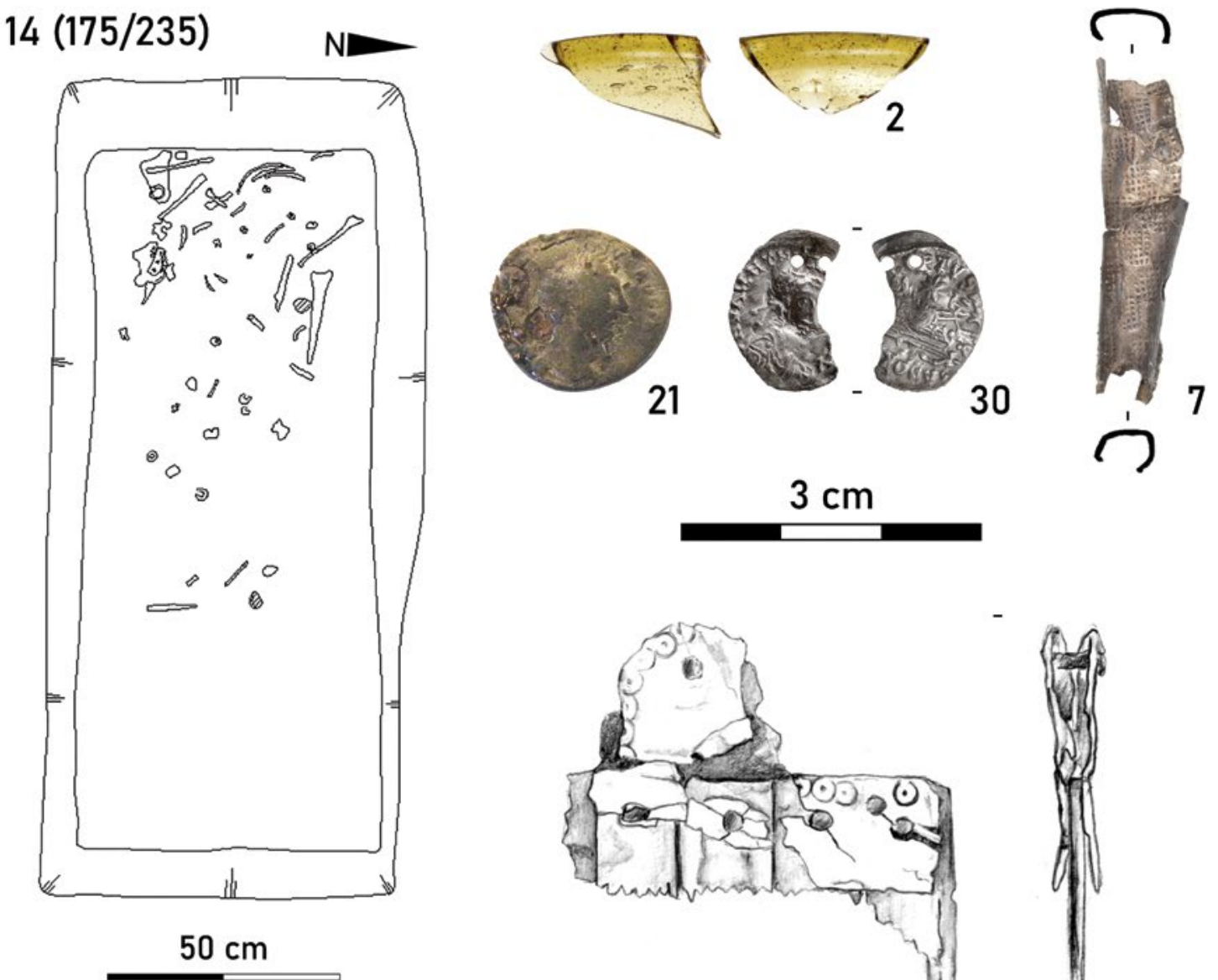

21
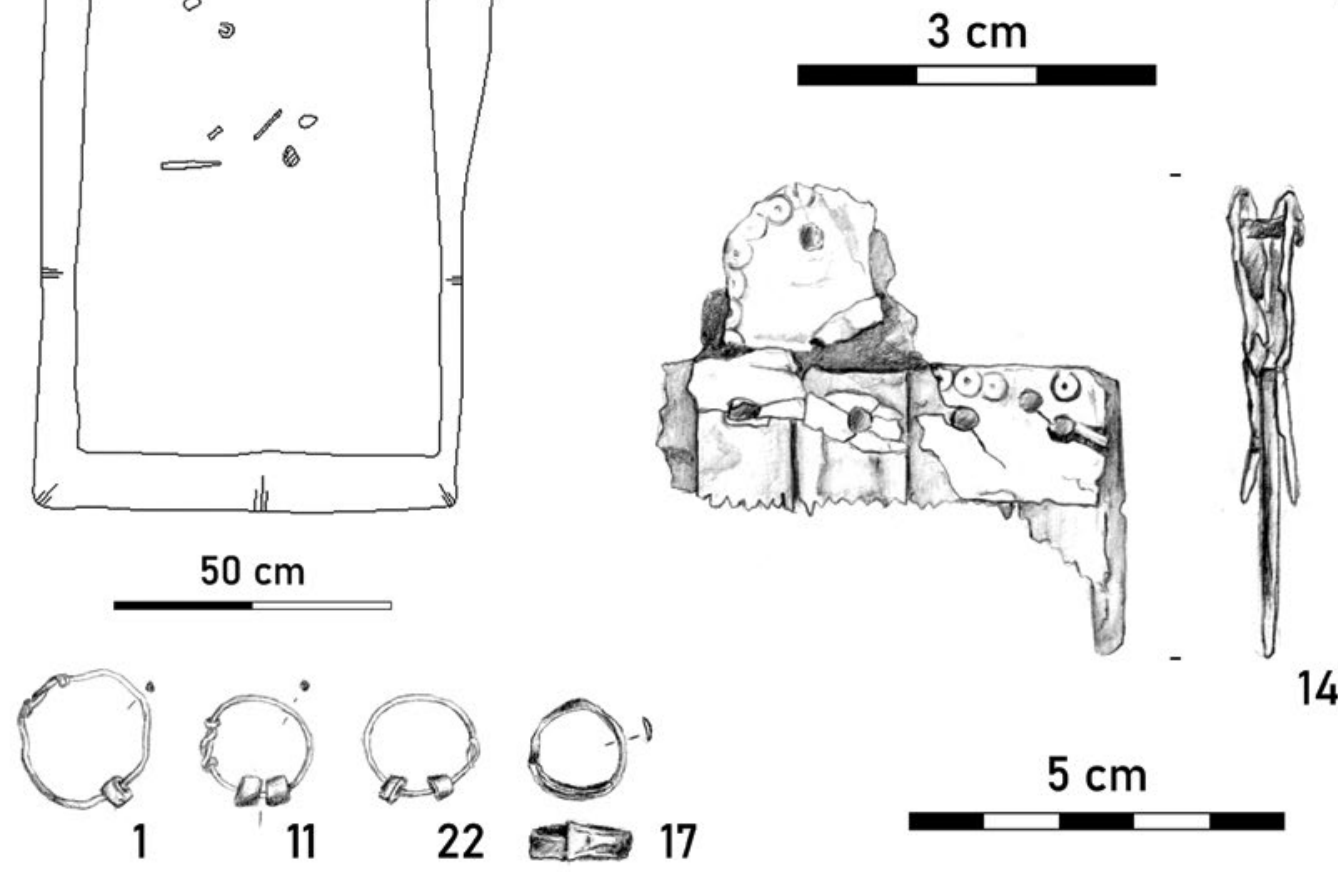

(0) 00
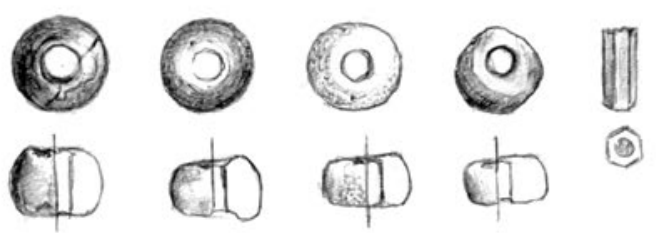

(2)

58
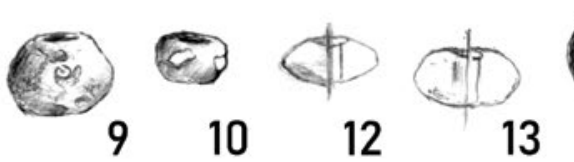

29

$26 \quad 18$

$28 \quad 23$
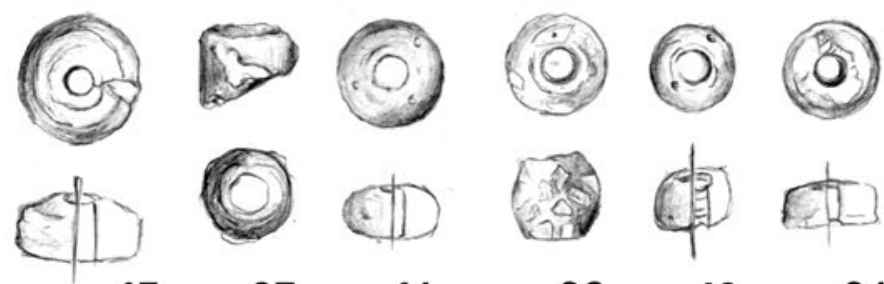

(i)

南

$15 \quad 27 \quad 16$

$\begin{array}{lll}20 & 19 & 24\end{array}$

13. kép. M3-58. lelőhely: 14 . sír

Fig. 13. Site M3-58: Grave 14 

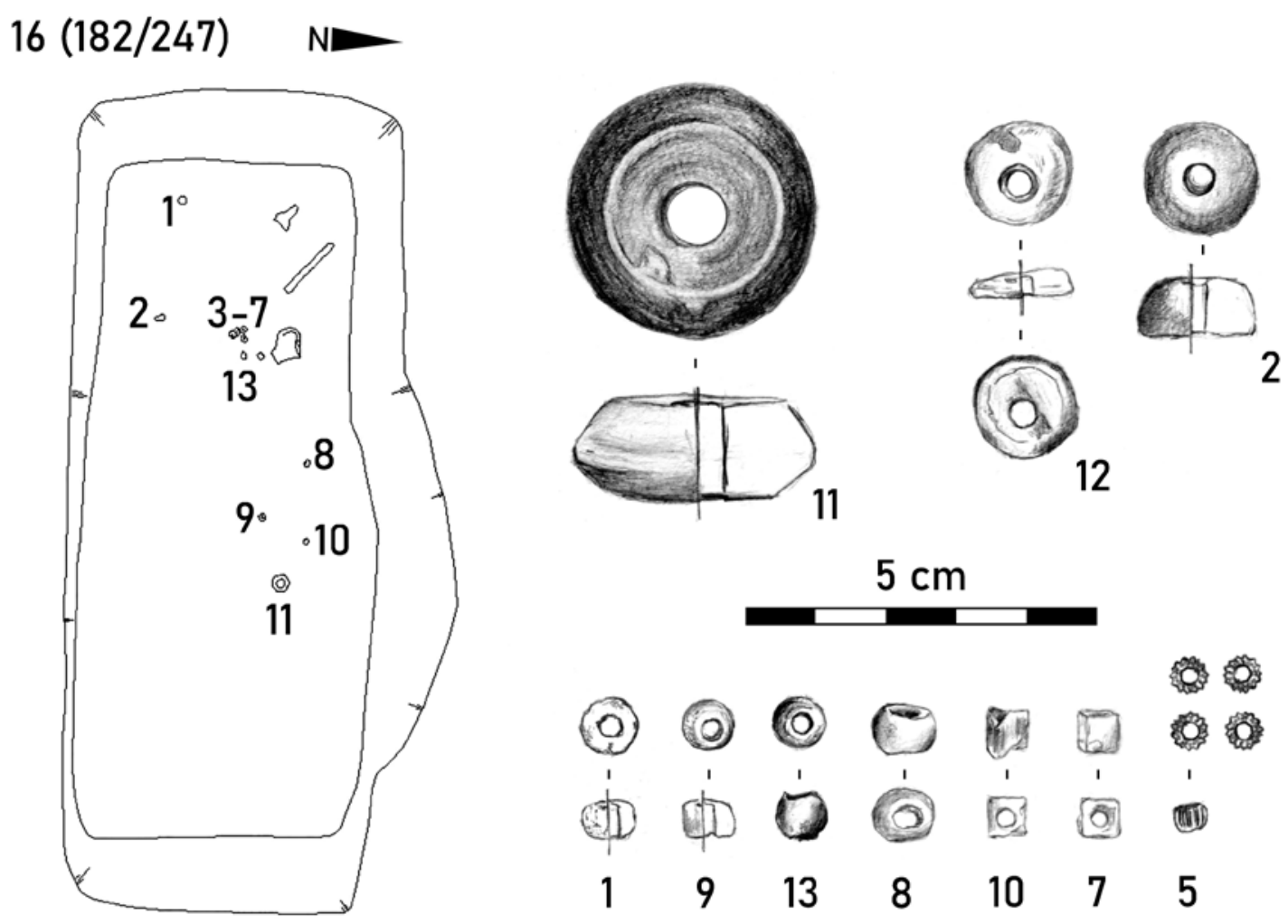

11 2
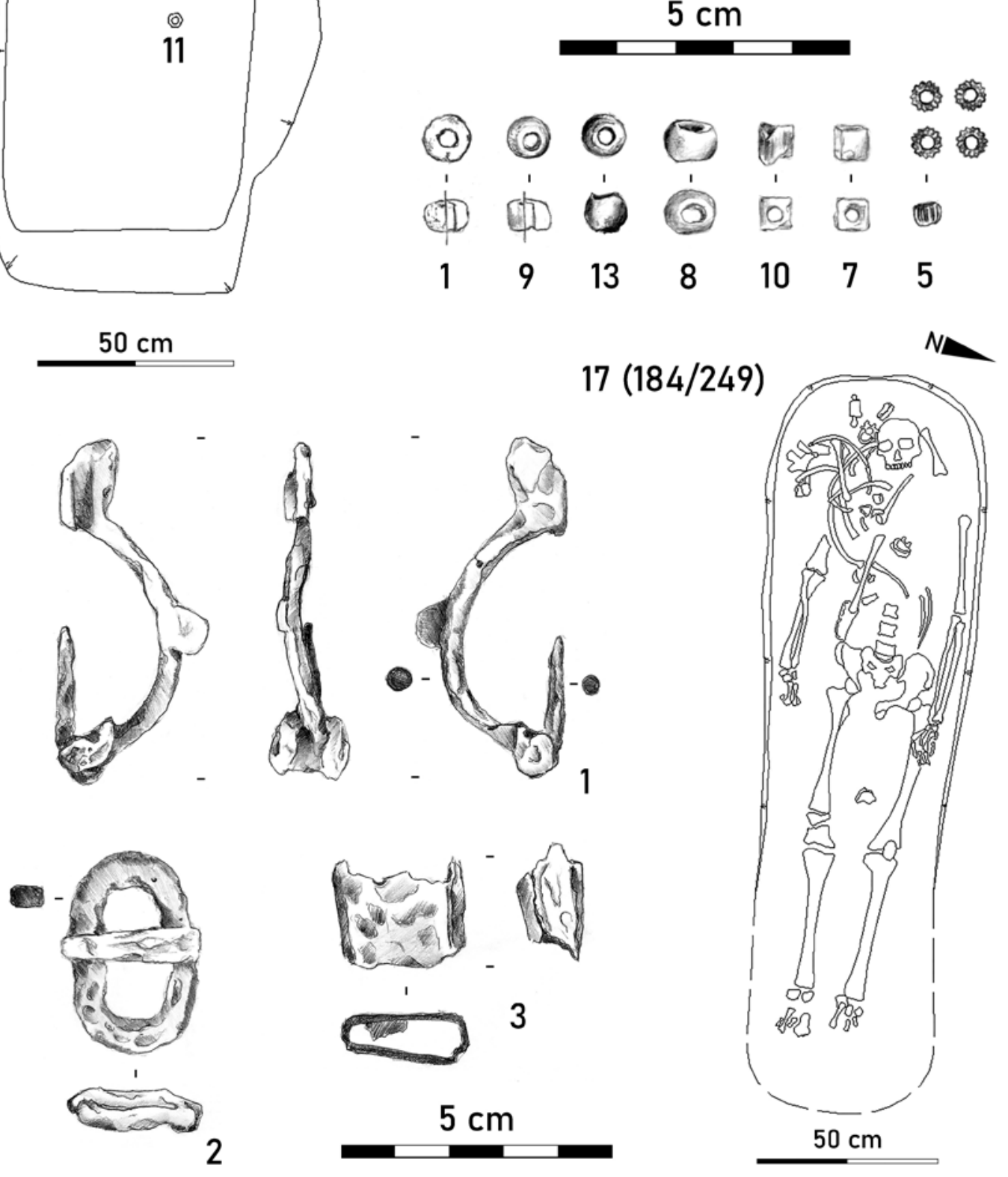

14. kép. M3-58. lelőhely: 16., 17. sír

Fig. 14. Site M3-58: Grave 16, 17 
$19(63 / 253)$

$18(63 / 70)$
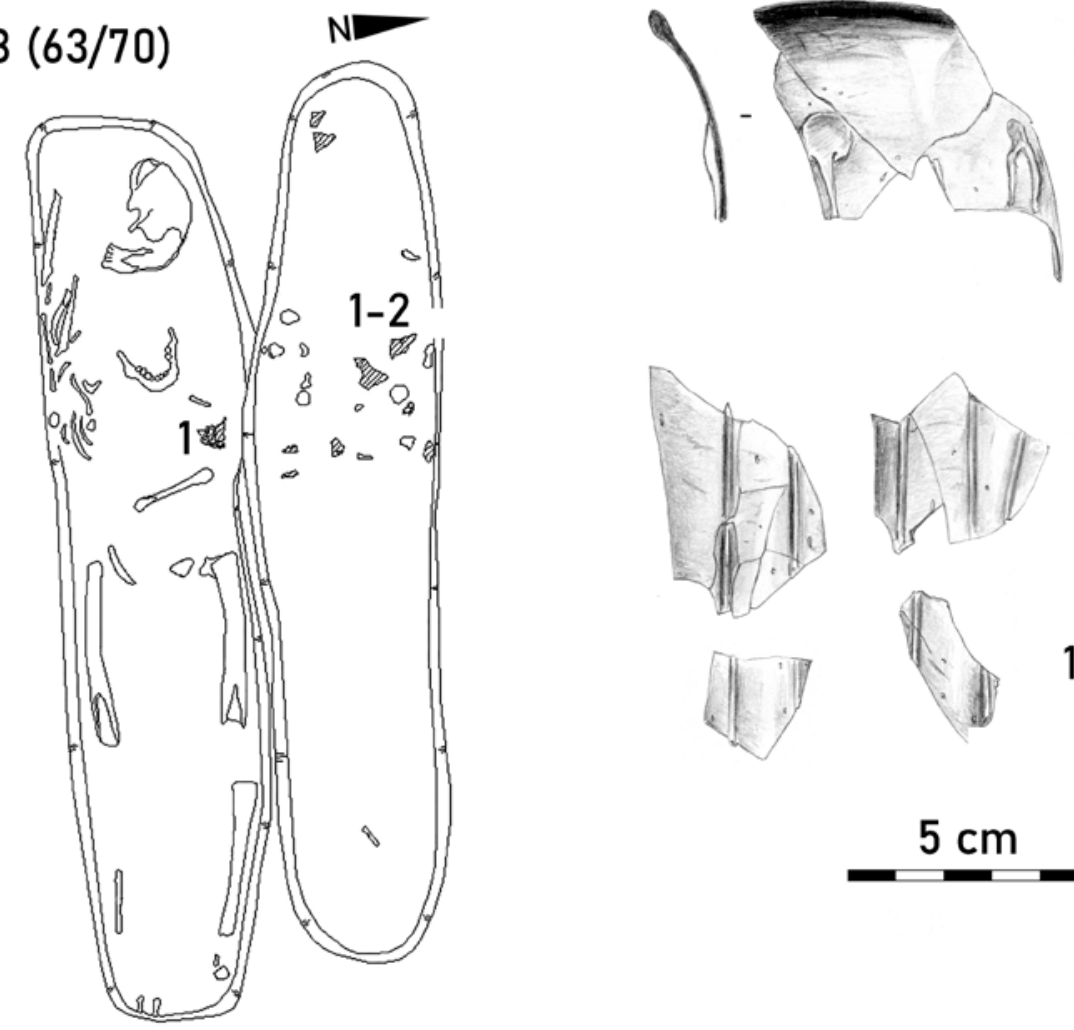

2
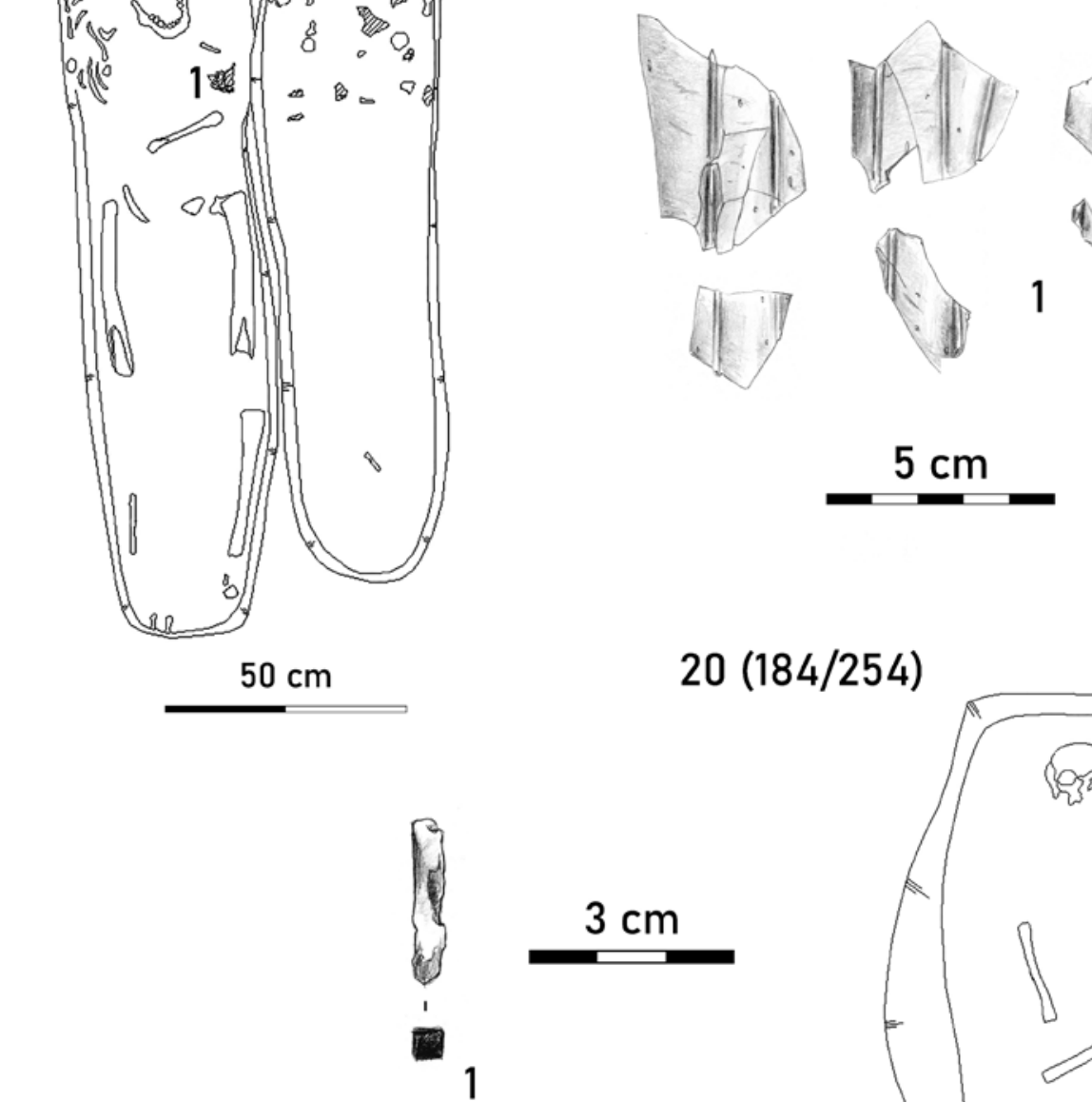

$5 \mathrm{~cm}$

szórvány
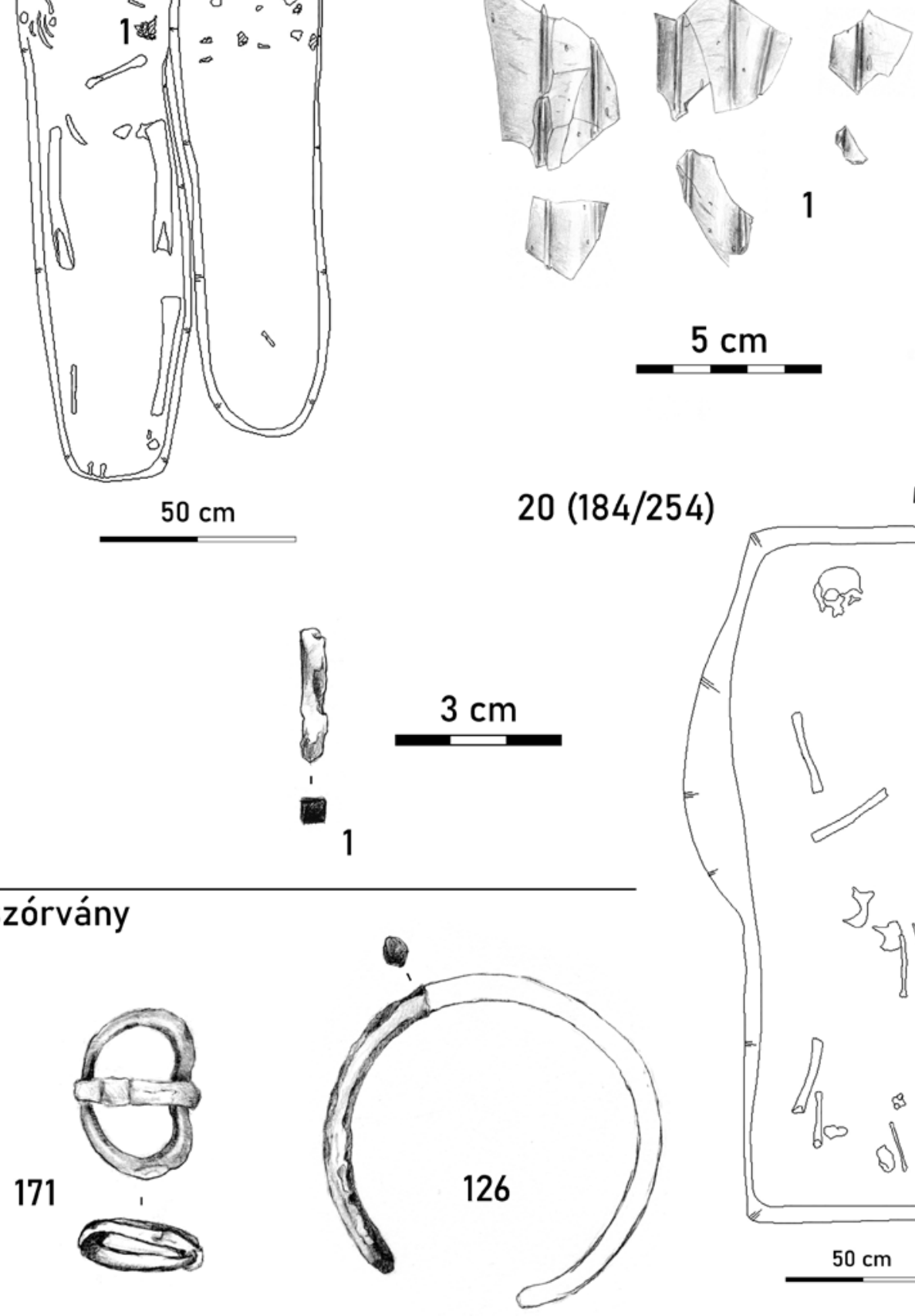

1

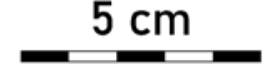

$0(184 / 254)$

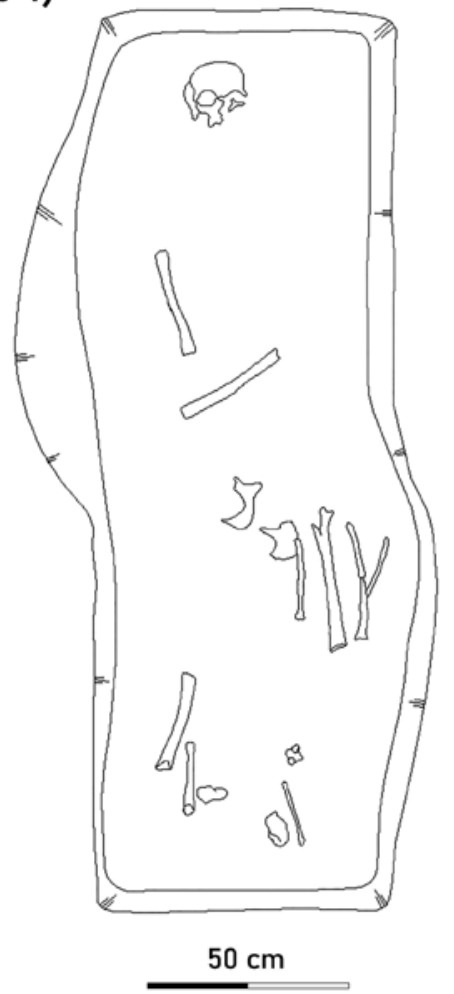

15. kép. M3-58. lelőhely: 18., 19., 20. sír és szórványleletek

Fig. 15. Site M3-58: Grave 18, 19, 20 and stray finds 


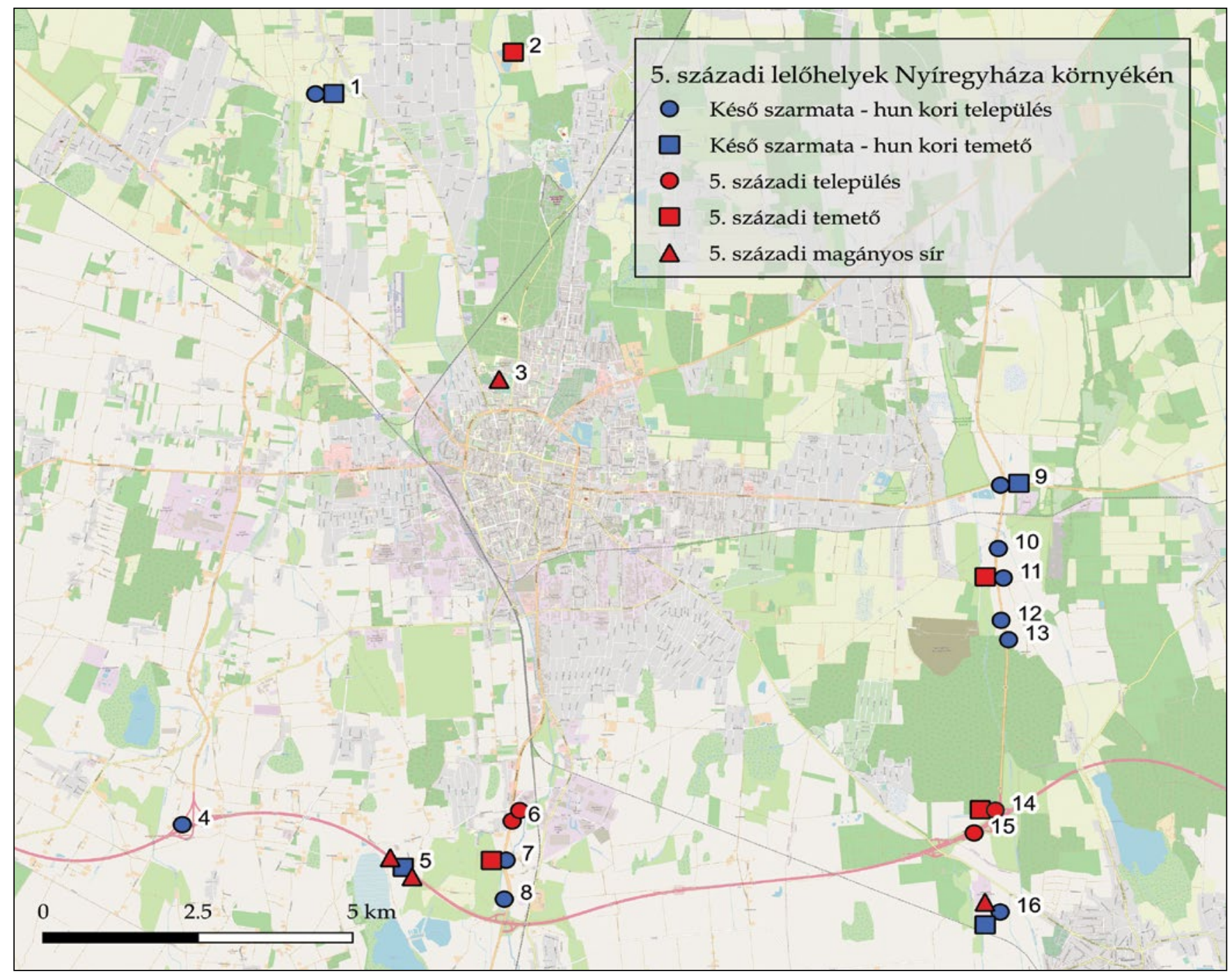

16. kép. 5. századi lelőhelyek Nyíregyháza környékén. 1: Nyíregyháza, Nyulas-tói-csatornától D-re; 2: Kótaj, Verba-tanya, Halastó; 3: NyíregyházaStadion; 4: Nyíregyháza, Mandabokor II. (nyugati elkerülő 36. Ih.); 5: Nyíregyháza, Szelkó-dúlő (M3-148/b lelőhely) és Nyíregyháza-Rozsrétszőlő, Szelkó-dülő, Rozsréti kaszáló (M3-214. és M3-215. lelőhely); 6: Nyíregyháza, Császárszállás-Varga tábla (M3-182. lelőhely) és Nyíregyháza, Ipari Park IV. (Marso telephely); 7: Nyíregyháza-Rozsrétszőlő, Nevelős homokbányától D-re (Császárszállás, Varga tábla III., M3-36/c lelőhely); 8: NyíregyházaCsászárszállás, Vasútállomástól Ny-ra (Butyka, M3-137. lelőhely); 9: Nyíregyháza-Oros, Kánya-hegy-dúlő (Üzleti Megapark 44. lelőhely); 10: Nyíregyháza, Úr Csere Észak (Oros, M3 keleti elkerülő 27. lelőhely); 11: Nyíregyháza, Úr Csere (Oros, M3 keleti elkerülő 26. lelőhely); 12: Nyíregyháza, Úr Cserétől D-re (M3 keleti elkerülő 33. lelőhely); 13: Nyíregyháza, Lévai-tag (M3 keleti elkerülő 53. lelőhely); 14: Nyíregyháza, Csorda-Páskum II. (M3-58. lelőhely); 15: Nyíregyháza, Csorda-Páskum I. (M3-14. lelőhely); 16: Nagykálló, Kis-Ludastó-dúlő (a hivatkozásokhoz Id. 40. jegyzet)

Fig. 16. $5^{\text {th }}$-century sites in the vicinity of Nyíregyháza (Late Sarmatian - Hun-period settlements, Late Sarmatian - Hun-period cemeteries, $5^{\text {th }}$-century settlements, $5^{\text {th }}$-century cemeteries, $5^{\text {th }}$-century solitary graves. See Footnote 40 for references)

A sírmélységet vizsgálva, a mért adatok valószínüleg nem felelnek meg az eredeti mélységnek a homokdomb felszíne, illetve a humuszréteg vastagságának változásai miatt. A sírok átlagos mélysége a lehumuszolt felszíntől számítva - a bizonytalan sírok nélkül $-65 \mathrm{~cm}$ volt, ${ }^{44}$ amely jóval alatta marad az 5., illetve az 5-6. századi Kárpát-medencei temetők átlagos adatainak. A legsekélyebb temetkezést (21. sír, 20-25 éves nő) mindössze 15, a legmélyebbet (1. sír, 40-60 éves nö) 116-126 cm mélyre ásták, a legtöbb azonban 50-80 cm-re

${ }^{44}$ A 21-24. számú, sírgödör formájú, üres gödrökkel együtt $66 \mathrm{~cm}$. mélyedt a földbe. ${ }^{45} \mathrm{Az}$ 5. században használt temetők közül a zsámboki sírok átlagos mélysége jóval több, $132 \mathrm{~cm}$ volt, ${ }^{46}$ ahogy a mözsi sírok is mélyebbek voltak az itt megfigyelteknél. ${ }^{47} \mathrm{Az}$ 5. század második felére, végére keltezhető Mezőkeresztes-cethalmi sírok átlagos mélysége is $130 \mathrm{~cm}$-re

${ }^{45} \mathrm{~A}$ nemek és életkorok közti esetleges különbségeket a csak hiányosan rendelkezésünkre álló embercsontanyag miatt nem tudjuk tárgyalni.

${ }^{46} 13$ temetkezésből álló temetőrészlet: KIss 2015, 14.

${ }^{47} 80-200$ cm között; 96 síros temető (ÓDOR 2011). 
tehető. ${ }^{48} \mathrm{Az}$ 5-6. században használt - gepida kori - nagyobb sírszámú temetők mélységadatai követik az 5. századi jellegzetességeket. ${ }^{49}$

A sírok mélysége összefüggésben lehetett a halott életkorával és társadalmi státuszával is, de ezt a kérdést a csak hiányosan rendelkezésünkre álló csontanyag miatt nem tudjuk részletesen vizsgálni. Emellett a nyíregyházi temető sírjait erősen megbolygatták, ami szintén megnehezíti a mellékletadási szokások és a sírméretek közti összefüggések feltárását. A leggazdagabb felszerelésű sírok gyerekekhez és fiatalokhoz kötődtek (3., 6., 14., valamint a 16. sír, amely egy ismeretlen életkorú egyénhez tartozott, ám mérete alapján gyereksír lehetett), ezek 63-79 cm-es mélysége megfelel a temetőben tapasztalt általános képnek. A legmélyebb sír, a bolygatott, 1. sz. női temetkezés mellékletet nem tartalmazott. A leletekkel leggazdagabban ellátott férfisír csupán $50 \mathrm{~cm}$ mély volt. Összességében elmondhatjuk, hogy az itt megfigyelhető kevés adat alapján nem mutatkozik összefüggés a sírmélység és a sír „gazdagsága” között.

A temetkezések alapterülete a nagyméretü bolygatások miatt nem vizsgálható minden esetben. A sírok téglalap alakúak, hosszúságuk az elhunyt testméretével állt összefüggésben. Ennek megfelelően a férfisírok voltak a leghosszabbak, 200 és $220 \mathrm{~cm}$ között. A női sírok sem sokban maradtak el ezek mögött 180 és 219 cm közötti hosszúságukkal, a gyermeksírok mérete viszont csupán 153-166 cm volt. Koporsóra utaló nyomot nem lehetett megfigyelni a temetőben.

A gazdag mellékletü gyereksírok (6., 14., 16.? sír) kérdését a hiányos antropológiai adatok miatt e tanulmányban csak röviden érintjük. Általános megfigyelés, hogy a nagyobb lánygyerekek, fiatal lányok sírjában gyakrabban fordulnak elö ékszerek és amulettek, mint a kisgyerekek és idős nők temetkezésében. Az is széles körben jellemző a népvándorlás korban, hogy a női mellékletek fiatalabb életkorban tűnnek fel, mint a férfiakra utaló tárgyak. Ezt a jelenséget a termékenységgel és a házassággal hozzák összefüggésbe. ${ }^{50} \mathrm{Az} 5$. században azonban nem ritkaság, hogy a kisebb gyermekeket is díszesen felöltöztetik és változatos mellékletekkel látják el a temetési szertartás során (ld. 6. sír, ékszerekkel, amulettekkel és edénykészlettel). ${ }^{51}$ Mindez tükrözhet egy vágyott, de be nem teljesült státuszt, illetve kifejezheti a családnak a gyermek elvesztése fölött érzett fájdalmát is. A 14. sír esetén azt is meg kell még jegyeznünk, hogy a temető egyik legkorábbi, alapító sírjáról lehet szó. Az alapító sírok gazdagabb leletanyaga ugyancsak általános a kora középkorban. ${ }^{52}$

\footnotetext{
${ }^{48}$ SimONyi 1999, 72-73.

${ }^{49} \mathrm{~A}$ Hódmezővásárhely-kishomoki temető sírjainak átlagmélysége $144 \mathrm{~cm}$, ez az adat Szentes-Kökényzugon $129 \mathrm{~cm}$, Szentes-Nagyhegyen $145 \mathrm{~cm}$, Kiszomboron $133 \mathrm{~cm}$, Szőregen $150 \mathrm{~cm}$, Szolnok-Szandán $141 \mathrm{~cm}$ (BóNA-NAGY 2002b, 77; NAGY 2004, 130). Hajdúnánás-Fürj-halom-dűlőn a lehumuszolt felszíntől számítva $101,5 \mathrm{~cm}$ volt a sírok átlagos mélysége, ám a kb. $40 \mathrm{~cm}$ magas humuszréteget beleszámítva ez is megfelel a Nagy Margit által közölt adatoknak (RÁcz 2019, 45).

${ }^{50}$ Halsall 2010, 298-299, 302-303; Brather 2005a, 21.

${ }^{51}$ Ld. pl. NAGY 2005a.

${ }^{52}$ BRATHER 2005b, 158.
}

Többszörös edénymelléklet (kerámiaedény és üvegpohár). A 6. számú gyermektemetkezést ugyan erősen megbolygatták, azonban a sír fej felőli vége érintetlen maradt: egy korsó, egy kisméretü fazék és egy kék üvegpohár töredékei sorakoztak a sírfal tövében (10. kép 1, 2, 9; 22. kép; 25. kép). A több edény - edénykészlet - sírba tételének szokása számos korabeli kultúrkörben megjelent. A korábbi, szarmata környezetben rendszerint egyetlen edény került a halott lábához. ${ }^{53}$ A fejnél elhelyezett, akár nagyobb számú edénymelléklet a Marosszentanna-Csernyahov kultúra 4. századi sírjaira jellemző, ${ }^{54}$ a kutatók egy része a jelenség alföldi feltünését a kultúrkör hun korban szétterjedő hatására vezeti vissza. ${ }^{55}$ Ugyanakkor az általunk tárgyalt esetben a többszörös edénymelléklet inkább római provinciális hagyományt tükröz: a római rítus szerint a sírokba helyezett készlet általában üvegpohárból és üvegpalackból-korsóból vagy ez utóbbiak helyett kerámiakorsóból áll. ${ }^{56}$ A rítuselem a limes menti, vegyes eredetű népesség temetői ${ }^{57}$ mellett a hun kor magányos sírjaiban, még a kifejezetten sztyeppei jellegü temetkezésekben is megjelent a Dunántúlon, a Dunától északra és az Alföldön egyaránt. ${ }^{58}$ Kerámia- és üvegedény vagy két kerámiaedény együttes sírba helyezése - ahogy általában az edénymellékletes sírok magasabb aránya is - inkább az 5. század első felére és a Dunától nyugatra volt jellemző, ami a provinciális hagyomány továbbélését bizonyítja e területen. ${ }^{59}$ A nyíregyházi

${ }^{53}$ Ezt a temetkezési rítust a térségben újonnan megtelepedő Tiszadob-kör sírjai esetén is helyi továbbélő vagy iráni jellegü hagyománynak tartja a kutatás (IstvánOvits-KulCsáR 1999, 82).

${ }^{54}$ KÖRÖSFŐI 2008, 196.

${ }^{55}$ IsTVÁNOVITS-KuLCSÁR 1999, 88. Elsősorban itt a Csongrádkenderföldeki temető leletanyagát említik. Az eredeti publikáció szerint az edénymellékletek többsége a fej környékén került elö, de csak a bizonytalan összetartozású B síregyüttes esetében merült fel a kettős edénymelléklet (PÁrduCz 1959, 310-317, Taf. XVI, 1, 7), illetve betöltésből származó töredékekröl van szó, mint Csongrád-Berzsenyi utca 2. sír (PÁrducz 1963, 18, Taf. I, 4, 5) vagy Csongrád-Kaszárnya 130. sír (PÁrduCZ 1963, 50, Abb. 11, Taf. VII, 27, Taf. XII, 2, 3, 6).

${ }^{56} \mathrm{Pl}$. Tejral 2011, 232-240.

${ }^{57}$ Pl. Páty lelőhelye az 5. század első feléből (ОттомÁNYi 2001, 48, további példákkal).

${ }^{58}$ Több példát említ Jaroslav Tejral (TejRal 2011, 232-240), illetve Tomka Péter az árpási sír elemzésekor (Томка 2001, 166). Két kerámiaedényből, egy korsóból és egy fazékból álló együttes, pl. Pusztataskony-Ledence (Ny. Kovacsóczy et al. 2021, Fig. 9).

${ }^{59}$ E megállapításokat a Kárpát-medencei 5. századi női temetkezések átfogó gyüjtésére alapoztuk: Rácz 2016, Tab. 1. Korsó-üvegpohár együttesekre példa az 5. század első feléből: Árpás-Dombiföld (Томка 2001, 162-163), Csongrád-Kaszárnya, 126. sír (PÁrducz 1963, 48, Abb. 8, 2, Taf. X, 13, Taf. XI, 5), Drslavice, Mödling-Lerchengasse 2. sír, Regöly-Pénzesdomb, Szob-Kálváriadomb 2. sír, Untersiebenbrunn 1-2. sír. Az 5. sz. közepéről, második feléből: Tarnaméra-Urak-dűlője (BóNA-SzABó 2002, Taf. 58, 1-4), Barabás-Bagolyvár, Hrtkovci-Vranja, Szurdokpüspöki 4. sír, Hódmezővásárhely-Kishomok 105. sír, Sângeorgiu de Mureș/ Marosszentgyörgy-Kerekdomb (Dовоs et al. 2021). Az 5. sz. végéről - 6. sz. elejéről: Dunaújváros-Öreghegy (a női sírokat közlő irodalmakhoz ld. RÁcz 2016, Tab. 1). 
példához hasonlóan agyagkorsóból, fazékból és üvegpohárból álló készlet volt az árpási és a regölyi hun kori elit temetkezésekben.$^{60} \mathrm{~A}$ század közepén és második felében-végén a szokás még fellelhető a Kárpát-medencében, a nyíregyházi lelőhelyhez legközelebb a Barabás-bagolyvári gazdag női leletegyüttesben. ${ }^{61}$ A gepida korban a Hódmezővásárhely-kishomoki temető egy korai sírja örzi még e hagyományt. ${ }^{62}$

$\mathrm{Az}$ általunk vizsgált temető különlegessége továbbá, hogy legalább négy sírjában került elő üvegpohár. Az üvegedények sírba tétele általánosnak mondható az 5. században mind az egykori Pannonia, mind a Barbaricum területén - Kiss Attila 1999-es gyüjtésében 39 esetet sorol fel ${ }^{63}$-, ám a szokás inkább a magányos sírok és a kisebb sírcsoportok egy-egy temetkezésére jellemző. Ezek mellett a Csongrádkenderföldeki lelőhelyet említhetjük meg, amelynek öt sírjában volt üvegedény, valamint a pátyi kis temetőt, ahol két gyermeksírban fordult elő üvegmelléklet. ${ }^{64}$ Azt is meg kell jegyeznünk, hogy az üvegedények sírba tételének szokása, ugyan kis számban, de az alföldi szarmaták körében is elterjedt, és az északkeleti területeken éppen a szarmata kor legkésőbbi időszakában jelent meg. ${ }^{65}$ A Tiszadob-szigeti, a 4-5. század fordulójára tehető temetőnek két sírjában volt üvegpohár. ${ }^{66}$

Sírbolygatás. A nyíregyházi temető erősen bolygatott volt, két sírt kivéve nem volt olyan temetkezés, amelyet részlegesen vagy teljesen meg ne bolygattak, illetve ki ne raboltak volna. A népvándorlás kori temetkezésekkel foglalkozó kutatás a sírok felnyitásának jelenségét értékes tárgyak kiemelésével hozza összefüggésbe, és nem egyéb, rituális cselekménnyel. ${ }^{67}$ A sírgödrök betöltésében a bolygatási gödröket jól meg lehetett figyelni: a legtöbb esetben a sírgödör közepén, vagy a nyugati feléhez közelebb ásták a „rablóaknákat”.

A temetkezéseket nem egyforma mértékben dúlták fel, a bolygatásokat három csoportba sorolhatjuk.$^{68} \mathrm{~A} 17$. sírban a csontokat kevéssé zilálták szét, a váz legnagyobb része anatómiai rendben feküdt, csak a bordák és a csigolyák egy része volt bolygatott. A következő csoportnál, ahova a legtöbb eset tartozott, a csontok néhány kivételtől eltekintve nem a helyü-

\footnotetext{
${ }^{60}$ Toмка 2001, 162-163, 5-6. kép; MÉszáros 1970, 80-84, 16-19. kép.

${ }^{61}$ BónA 2002a.

${ }^{62} 105$. sír: agyagkorsó és üvegpohár (NAGY 2004, 167; BóNA-NAGY 2002b, 75).

${ }^{63}$ KIss 1999, 238.

${ }^{64}$ Kiss 1999, 238; PÁRdUCZ 1959, 387; OtтomÁnyi 2001.

${ }^{65}$ FenYvesi 2020, 64, 1. térkép. A környékről Nagykálló, Kis-Ludastó-dűlő (Ipari park) és Nyíregyháza-Oros, keleti elkerülő 24. lelőhelyet említhetjük (Fenyvesi 2020, Kat. IB.3 és IB.8).

${ }^{66}$ Istvánovits 1993, 25. és 34. sír.

${ }^{67}$ Erről összefoglalóan: Dовоs 2014a; Dовоs 2017, 107.

${ }^{68}$ Ld. még Nagy Margit csoportosítását a Hódmezővásárhely-kishomoki temető elemzése során: BóNA-NAGY 2002b, 91-92; NAGY 2004, 141, valamint Dовоs 2017, 96-97; Rácz 2019, 53.
}

kön, hanem a sírok középső, illetve a nyugati részében voltak összetolva, ahol eredetileg a test középső és fej felöli része feküdt. ${ }^{69}$ Olyan eset is előfordult (4. sír), amikor a csontok nagyjából egy vonalban feküdtek, a bolygatási gödör szélét jelezve. A lábak vagy azok egy része néhány esetben érintetlen maradt (pl. 3. és 11. sír). A harmadik csoportban a bolygatás még nagyobb mértékű: a csontok nagy része hiányzott a sírból vagy a betöltésből került eloo. ${ }^{70}$ A 6 . sírban, amely a mellékletek számát tekintve az egyik leggazdagabb volt, a teljes vázból összesen két hosszúcsont maradt meg. A 12. és valószínűleg a 21. számú - sekélyen fekvő, melléklet nélküli, a humuszolás során megsérült - női sír érintetlen maradt.

A női sírok felsőtest felőli részét talán a fibulák kiemelése céljából bolygatták meg. ${ }^{71}$ Ugyanakkor a 6. számú gyereksírban - bár jól látszott a bolygatási gödör, és ahogy fentebb írtuk, csont is alig maradt a sírgödörben - a kengyelfibula a gödör közepén maradt.

A csontváz helyzetéből, állapotából megpróbálhatunk következtetéseket levonni a temetés és a sír felnyitása között eltelt időre. A különféle, a test lebomlására hatással lévő tényezőktől függően általában 3-15 évvel számolnak a teljes csontvázzá alakulásig, a nyíregyházi sírok esetében is eltelhetett legalább ennyi idő a sírba helyezés és a bolygatás között. ${ }^{72}$ Elképzelhetö, hogy mindez a temető és a mellette elhelyezkedő telep felhagyásával egy időben vagy már ez után történt. ${ }^{73}$ Nem tudjuk, hogy a nyíregyházi sírokat egyszerre nyitották-e fel. „Bolygatási kampányokat”, egyszerre nyitva lévő sírokat a legbiztosabban úgy lehet azonosítani, ha egy egyén csontjai egy másik, szomszédos sírgödörbe kerülnek át, vagy a sírban eredetileg fekvő csontvázhoz nem tartozó maradványok kerülnek elő másodlagos helyzetben. Ilyen adatokat azonban a nyíregyházi temető elemzésekor nem állt módunkban felhasználni. ${ }^{74}$

A nyíregyházi temető nagyfokú bolygatása nem egyedülálló az 5. században. Hasonló mértékben feldúlták például a Nagydémen feltárt hun kori temetőt, amelynek 34 sírjából mindössze négy gyermek- és egy sekélyre ásott felnőtt sír maradt érintetlen. ${ }^{75}$

\footnotetext{
${ }^{69}$ Ebbe a csoportba sorolható az 1-4., 8-9., 14-16., 20. számú sír. Hasonló jelenségekre mutat rá Nagy Margit a Hódmezővásárhely-kishomoki gepida temető elemzésekor. Az ottani síroknál a rablóaknákat ráásták a még ép koporsókra, azokat áttörve egy szerszám segítségével összeszedték a fémtárgyakat, és ekkor kerültek a csontok is kupacokba (NAGY 2004, 141-142).

${ }^{70}$ Ide tartozik az 5-6., 10., 13. sír

${ }^{71}$ Nagy 2004, 142.

${ }^{72}$ Aspöcк 2003, 242-243.

${ }^{73}$ Nagy Margit a Hódmezővásárhely-kishomoki lelőhely esetében azzal számolt, hogy a „fosztogatók” egy felhagyott, már nem müködő temető területén végezték tevékenységüket (NAGY 2004, 141).

${ }^{74}$ RÁCZ 2019, 54; ILON 1999, 32-33.

${ }^{75}$ ILON 1999, 32.
} 


\section{A régészeti leletanyag}

\section{Viseleti elemek, ékszerek}

\section{Gyöngyök}

A temetőben nyugvó népesség viseletének - a temetési reprezentációhoz tartozó öltözetnek mindenképpen - fontos részét képezték a gyöngyök, három sírban fordultak elö (10., 13., 14., 17. képek). A 6. sír egy kisgyermek temetkezése volt, a 14. és 16. sírból származó embercsontokat egyelöre nem tudtuk megvizsgálni, ám az ásatáson tett megfigyelések szerint ezek is gyereksírok lehettek. ${ }^{76}$ A 6 . és a 14 . temetkezés a gyöngyökön kívül egyéb viseleti elemekkel, mellékletekkel is gazdagon el volt látva. Az 5. századi Közép-Európában szokás volt, hogy sokféle anyagú és formájú gyöngyöt használtak egy készletben, gyakran fémcsüngőkkel kiegészítve. ${ }^{77}$ A nyíregyházi temetőben is megfigyelhető a gyöngyök sokszínűsége, ám a sírok erős bolygatása miatt nem tudjuk, hogy hol helyezkedtek el eredetileg, így funkciójuk is bizonytalan: kérdéses, hogy melyeket hordták nyakban láncként és melyeket övfüggö, tarsoly, esetleg kar díszeként vagy fibulához kapcsolódó csüngődíszként. Ugyanakkor e korszak viseletére az is jellemző, hogy a különböző funkciókhoz különböző méretü gyöngyök kapcsolódhatnak. A fejnél és a nyakban általában kisebb, a test középső részén és a lábak mentén nagyobb, gyakran borostyánból faragott vagy díszített üveggyöngyök fordulnak elő. ${ }^{78}$ A gazdag gyöngyviseletet bolygatatlan sírok alapján lehet rekonstruálni, ezek közé tartozik például a Mezőkövesd-mocsolyási lemezfibulás női sír az 5. század közepéről vagy Viminacium-Burdelj (Kostolac) lelőhely több temetkezése is. ${ }^{79}$

A 6. sírból három nagyméretü (kb. 1,3-1,6 cm átmérőjü), lapított gömb alakú gyöngy került napvilágra, ezek közül kettő sötét színű (kék, illetve feketés) üveggyöngy, a harmadik színtelen, áttetsző üvegből készült (10. kép 5, 7-8). Ugyanebben a sírban egy csengő és két félhold alakú csüngő is elökerült.

A legtöbb gyöngy a 14. számú fiatal lány (?) sírjából került elő, összesen 22 darab, továbbá három, gyöngyökkel díszített karikacsüngő (13. kép; 17. kép). Anyagukat tekintve elöfordulnak itt üveg- és borostyángyöngyök, ez utóbbiból 3 darab. Néhány gyöngy díszített volt: kettő millefiori technikával készült, közülük az egyik foltos zöld alapszínü, ellentett helyzetben két vöröses, négyszirmú virágot mintázó díszítéssel (17. kép 4), a másik, kék alapszínü és piros mintás gyöngy szétesett. A rozettás díszű millefiori gyöngyök a késő római kor végén tűntek föl. ${ }^{80}$ Három üveggyöngyöt utólag

\footnotetext{
${ }^{76} \mathrm{~A}$ 14. sír az ásatási megfigyelések szerint idősebb gyermek volt, a sírméret $(\mathrm{h}: 174 \mathrm{~cm})$ alapján pedig a 16 . sír is gyermektemetkezés lehetett.

${ }^{77}$ B. ТóTH 1994, 299.

${ }^{78}$ Rácz 2016, 312-314. Nagy Margit a Hódmezővásárhely-kishomoki temető 77. és 105. sírjánál ír a nagyobb, korong alakúra faragott borostyángyöngyök díszfüggőn való viseletéről (BóNA-NAGY 2002b, 67, 75; NAGY 2004, 156).

${ }^{79}$ Lovász 1999, 257; IvANišEviĆ et al. 2006, Pl. 5.

${ }^{80}$ Tempelmann-MącZyŃska 1985, 59.
}

felvitt petty-, illetve hullámvonaldísszel láttak el: ezek gömbölyü, fekete alapszínű, 1-1,5 cm átmérőjü gyöngyök, az egyik, erősen kopott példányt eredetileg sürü fehér, szétszórt pöttyök, a másikat szabálytalan, kék „szemek” és az ezeket összekötő folyatott vonalak díszítik (17. kép 2). Egy további, barnásvörös színü, hengeres példányon szabálytalan, fehér folyatott hullámvonal dísz figyelhető meg (17. kép 3). A sötét alapszínű szétszórt pettyes gyöngyök a késő császárkorban jelentek meg, és a kora népvándorlás kor női sírjainak széles körben elterjedt tárgytípusát képviselik. ${ }^{81} \mathrm{~A}$ szemes gyöngyök ugyan ritkán, de nagy területen fordulnak elö a késő császárkortól kezdve. ${ }^{82}$ A hullámvonal-folyatott díszű gyöngyök ugyancsak a késő császárkor óta figyelhetőek meg a barbaricumi emlékanyagban. ${ }^{83}$

A többi üveggyöngy között előfordulnak nagyobb méretű (1 cm-nél nagyobb átméröjü), lapított gömb alakú, színtelen, vízszínü, kék és vörös üveggyöngyök (5 darab), valamint bikónikus, színtelen üveggyöngy. A kisebb méretüek között találunk hengeres fekete, valamint egészen apró, kb. $0,25 \mathrm{~cm}$ átmérőjű zöld gyöngyöket. Előfordult még a készletben egy hatszögletű hasáb alakú, kopott, zöld üveggyöngy, ami a késő római időszak kedvelt gyöngytípusa volt. ${ }^{84} \mathrm{Az}$ ezüstkarikára füzött gyöngyök fekete, illetve zöld, hengeres formák. A három borostyángyöngy korong-, illetve lapított gömb alakú, az egyik példányt körbefutó, vésett vonal díszíti. ${ }^{85}$

A 14. sír fej felöli végében volt a 2 millefiori gyöngy, a fekete hordó alakú gyöngyök, valamint az apró kölesgyöngy, ezek talán a nyaklánchoz tartoztak. A mellkas és a derék tájékán feküdtek a nagyobb méretü pettyes, folyatott díszü, illetve színtelen üveggyöngyök, öv vagy tarsoly, esetleg a mellkas díszeként szolgálhattak. Sajnos néhány gyöngy, így a borostyánból készült példányok helyzete ismeretlen.

A 16. számú sír összesen 15 gyöngyöt tartalmazott, legnagyobb részben üveggyöngyöket: volt köztük lapított gömb alakú fehér és piros, gömbölyü sötétkék, hasáb alakú bordó, lecsapott sarkú hasáb alakú kék üveggyöngy, valamint egészen apró, gömbölyü fekete kölesgyöngyök (14. kép). Ezeken kívül $4 \mathrm{db}$ kisméretü, bordázott fémpántból hajlított és $2 \mathrm{db}$ nagyméretű borostyángyöngy is volt a temetkezésben. A lecsapott sarkú hasáb alakú gyöngyök a császárkorra és a kora népvándorlás korra jellemzőek, a germán és avar korszakokban már jóval ritkábban fordulnak elö. ${ }^{86}$

Az előző két sírhoz hasonlóan ez a temetkezés is erősen bolygatott volt, a csontváz majdnem teljesen hiányzott, a gyöngyök a sír nyugati részén, a valamikori mellkas helyén összpontosultak; ezeken kívül még három gyöngy volt a sír közepe táján, ahol egy orsókarika is feküdt.

\footnotetext{
${ }^{81}$ NAGY 2005a, 99-100; BÁRKÁNYI 2010, 13-14.

${ }^{82}$ Tempelmann-MąCZYŃSKa 1985, 62.

${ }^{83}$ TempelmanN-MączyńsKa 1985, 55-56.

${ }^{84}$ De még az avar korban is előfordul belőle egy-egy példány (BÁRKáNYi 2010, 28).

${ }^{85}$ A nagyméretü borostyángyöngyökről pl. B. TóTH 1994, 296.

${ }^{86}$ BÁRKÁNYi 2010, 29.
} 


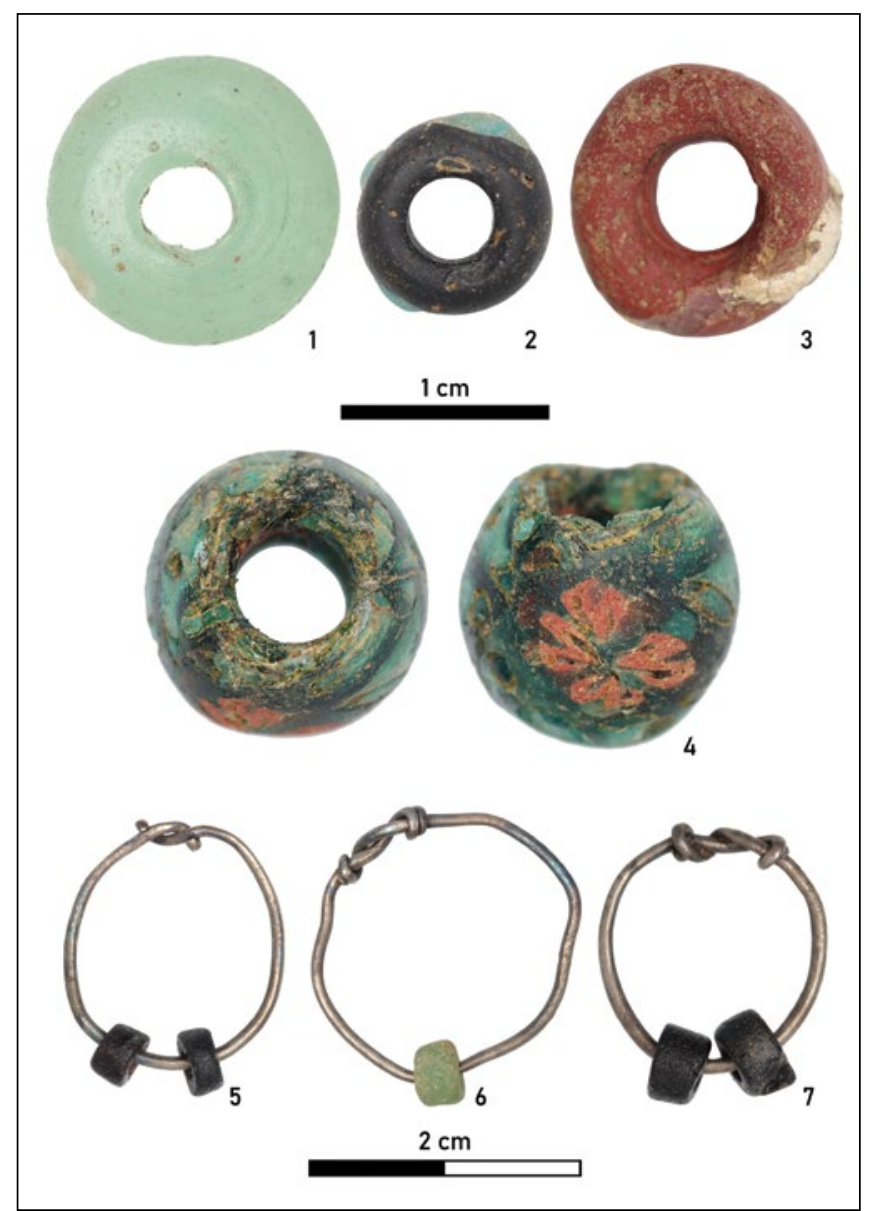

17. kép. M3-58. lelőhely: gyöngyök a 6. (1) és a 14. (2-7) sírból

Fig. 17. Site M3-58: glass beads from Grave $6(1)$ and 14 (2-7)

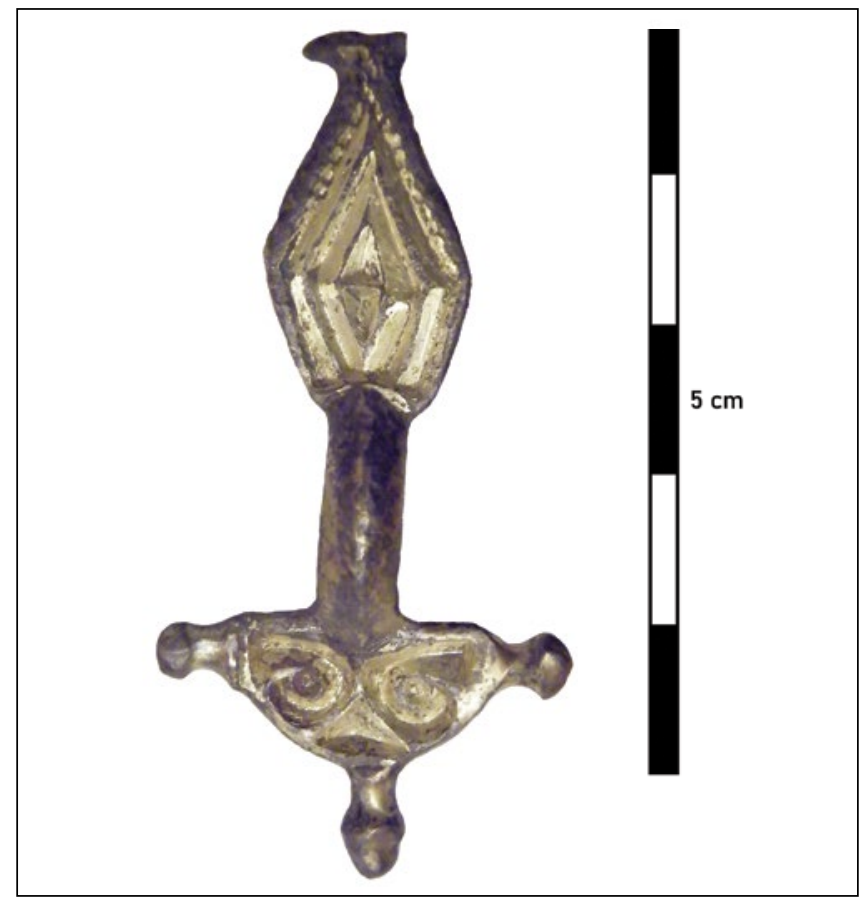

2. táblázat. A Nyíregyháza-M3-58. lelőhelyen feltárt temető gyöngyleletei anyag és forma szerint

Table 2. Nyíregyháza, Site M3-58. Pearl finds from the cemetery according to material and form

\begin{tabular}{|c|c|c|}
\hline Forma, díszítés & Sírszám & $\begin{array}{l}\text { Mérettartomány } \\
\text { (átm.) }\end{array}$ \\
\hline \multicolumn{3}{|l|}{ Borostyángyöngy } \\
\hline \multirow{2}{*}{$\begin{array}{l}\text { Lapított gömb és félgömb } \\
\text { alakú }\end{array}$} & 14. sír & $1,13 \mathrm{~cm}$ \\
\hline & 16. sír & $1,7 \mathrm{~cm}$ \\
\hline \multirow[t]{2}{*}{ Korong alakú } & $\begin{array}{l}\text { 14. sír } \\
\text { (vésett } \\
\text { vonaldísszel) }\end{array}$ & $\begin{array}{l}1,25- \\
1,65 \mathrm{~cm}\end{array}$ \\
\hline & 16. sír & $1,5 \mathrm{~cm}$ \\
\hline \multicolumn{3}{|l|}{ Fémgyöngy } \\
\hline $\begin{array}{l}\text { Lapított gömb alakú, } \\
\text { bordázott }\end{array}$ & 16. sír & $0,45-0,54 \mathrm{~cm}$ \\
\hline \multicolumn{3}{|l|}{ Üveggyöngy } \\
\hline Gömbölyú & 16. sír & $0,78 \mathrm{~cm}$ \\
\hline \multirow[t]{3}{*}{ Lapított gömb alakú } & 6. sír & $1,35-1,56 \mathrm{~cm}$ \\
\hline & 14. sír & $\begin{array}{l}1,05- \\
1,92 \mathrm{~cm}\end{array}$ \\
\hline & 16. sír & $0,76-0,9 \mathrm{~cm}$ \\
\hline Hordó alakú & 14. sír & $0,6-0,65 \mathrm{~cm}$ \\
\hline Bikónikus & 14. sír & $1,37 \mathrm{~cm}$ \\
\hline \multirow[t]{2}{*}{ Kölesgyöngy (<5 mm) } & 14. sír & $0,25-0,27 \mathrm{~cm}$ \\
\hline & 16. sír & $0,22-0,23 \mathrm{~cm}$ \\
\hline Henger alakú & $\begin{array}{l}\text { 14. sír } \\
\text { (ezüstkarikán) }\end{array}$ & $0,5-0,6 \mathrm{~cm}$ \\
\hline Hat oldalú hasáb alakú & 14. sír & $0,25 \mathrm{~cm}$ \\
\hline Négyzetes hasáb alakú & 16. sír & $0,58 \mathrm{~cm}$ \\
\hline $\begin{array}{l}\text { Lecsapott sarkú négyzetes } \\
\text { hasáb alakú }\end{array}$ & 16. sír & $0,55 \mathrm{~cm}$ \\
\hline \multicolumn{3}{|l|}{ Díszített üveggyöngy } \\
\hline $\begin{array}{l}\text { Lapított gömb alakú, } \\
\text { millefiori }\end{array}$ & 14. sír & $1,3 \mathrm{~cm}$ \\
\hline $\begin{array}{l}\text { Lapított gömb alakú, } \\
\text { pettyes }\end{array}$ & 14. sír & $1,5 \mathrm{~cm}$ \\
\hline $\begin{array}{l}\text { Lapított gömb alakú, } \\
\text { folyatott díszes }\end{array}$ & 14. sír & $0,95 \mathrm{~cm}$ \\
\hline $\begin{array}{l}\text { Hengeres, } \\
\text { hullámvonal-folyatott díszes }\end{array}$ & 14. sír & $1,26 \mathrm{~cm}$ \\
\hline
\end{tabular}

18. kép. M3-58. lelőhely: kengyelfibula a 6 . sírból

Fig. 18. Site M3-58: cast bow brooch from Grave 6 
Csüngők: csengő, félhold alakú csüngő és drótkarikára füzött gyöngyök

A 6. számú gyereksírban a gyöngyökhöz közel, a sír nyugati felében bronzcsengö ${ }^{87}$ feküdt (10. kép 4a). A kis csengők az 5. század középső harmadára és második felére jellemző, gyöngyökben és fém tartozékokban gazdag női viselet részét képezték. ${ }^{88}$ Hasonlókat ismerünk többek között Tiszaföldvár-Érhalom lelőhelyről, ahol egy felnőtt női temetkezésben a bal alkar és a kéz csontjai között 21 gyöngy társaságában került elö két csengö. ${ }^{89}$ A szurdokpüspöki 5. sírban a medence csontjai közt, szintén gyöngyökkel együtt feküdt a csengö. ${ }^{90}$

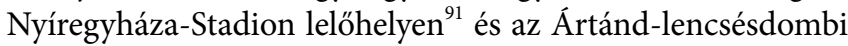
temetőben szórványként kerültek elő csengők, ${ }^{92}$ Domoszlón magányos női sírból ismerünk egy példányt (helyzete ismeretlen). ${ }^{93}$ Földrajzilag a fentiektől távolabb esik a nyugatbácskai, bodrogmonostorszegi (Bački Monoštor) 5. századi temető, ahol több sírban is volt csengő gyöngyök és állatfogból készített csüngők társaságában. Az 1899/VI. sírban a lábfejnél, az 1901/I. sírban a medence bal felén, illetve ugyancsak a lábfejnél feküdtek a bronzdrótra füzött csengők. ${ }^{94}$ A balatonszemesi 5. századi temető 268. sz. gyereksírjában a jobb alkarnál került elő két csengő bronzhuzal, gyöngyök és bronzcsüngő közelében, mindezeket Miháczi-Pálfi Anett tarsoly díszeiként határozta meg. ${ }^{95} \mathrm{~A}$ fentiekhez hasonlóan eredetileg a nyíregyházi csengő is csukló, öv vagy tarsoly dísze lehetett, amit a vele együtt talált vékony bronzdrót segítségével rögzítettek a viseletre. ${ }^{96} \mathrm{E}$ kis csengöknek apotropaikus, a gonosz szellemeket távol tartó szerepe lehetett. ${ }^{97}$

Ugyancsak a 6. sírban, a csengővel együtt félhold alakú bronzcsüngő töredékek - amelyekből két csüngő rekonstruálható - láttak napvilágot (10. kép 4b). A vékony öntvényeket rácsminta díszíti. A késő római - szarmata, pannoniai, valamint germán területekről származó - és kora népvándorláskori, fémlemezből kivágott lunulacsüngőket legutóbb Nagy Margit foglalta össze a mártélyi, számtalan amulettel eltemetett gyereksír tárgyalása során, ${ }^{98}$ ezen kívül Kiss Attila is készített egy katalógust a 4-5. századi lemezes és rekeszdíszes lunulákról a Szekszárd-palánki 217. sír elemzésekor. ${ }^{99}$ A korabeli daraboktól a harangodi példány abban különbözik,

${ }^{87} \mathrm{Nem}$ biztos, hogy a csengő alakú tárgy hangot is kiadott, jelenleg csak a felfüggesztésére szolgáló, a tetején áthúzott és összecsavart drót látszik a belsejében.

${ }^{88}$ Gyüjtését ld. RÁcz 2016, Tab. 1; MinÁCZI-PÁLFi 2018, 250-251.

${ }^{89} \mathrm{CSEH} 2005 \mathrm{~b}, 35$.

${ }^{90}$ BÁCSMEgI-Guba 2007, 27.

${ }^{91}$ Csallány 1958, 85, I. t. 17-19.

${ }^{92}$ Mesterházy 2005, 54, Taf. 5, 2.

${ }^{93}$ Bóna 2002b, 28, Taf. 4, 4.

${ }^{94}$ Gubitza 1899, 266-267 (bronz nyakdíszként), Gubitza 1902, 339 (csörgőként). Gubitza Kálmán leírásából arra lehet következtetni, hogy ezek a sírok bolygatottak voltak, így a gyöngyök-csüngök elhelyezkedésében nem lehetünk teljesen biztosak.

${ }^{95}$ MiHáCZI-PÁLFi 2018, 150-151.

${ }^{96}$ Rácz 2016, 314, 84. jegyzet; MiHáczi-PÁLFi 2018, 150-151.

${ }^{97}$ RAC, „Glocke”, 183.

${ }^{98}$ NAGY 2005a, 101, 9. kép; ld. még Mináczi-PÁlfi 2018, 151-152.

${ }^{99} \mathrm{Ez}$ a lista a szarmata példányokat nem tartalmazza (KIss 1996, 66). hogy egyrészt vékony öntvény, másrészt egész testét rácsminta díszíti, amire nem találtunk párhuzamot. A hasonló csüngők nyaklánc vagy fejdísz részei voltak.

A 14., gyöngyökben gazdag temetkezésből került elö három, ezüstkarikára füzött gyöngycsüngö, az egyik karikán egy, a másik kettőn két-két kis hengeres, zöld, illetve fekete gyöngydísszel, bolygatott helyzetben (13. kép 1, 11, 22; 17. kép 5-7). A tekercselt végü fémkarikára füzött gyöngyök - és egyéb csüngődíszek, állatfogak - a fent elemzett csengöhöz hasonlóan jellegzetes hun kori és hun kor utáni ékszerek. Az ezüstkarikára füzött tárgyak (nagyobb méretü gyöngyök, balta alakú csüngő, kónikus csüngőpár) meghatározó alkotóelemei például a smolini gazdag, fiatal női temetkezésnek, ezeket Jaroslav Tejral ruhadíszként határozta meg és az 5. század közepére keltezte. ${ }^{100}$ A csengő kapcsán már emlegetett bodrogmonostorszegi (Bački Monoštor) sírokban is előfordulnak a fémkarikára füzött tárgyak, köztük lecsapott sarkú hasábos gyöngyök. ${ }^{101}$

\section{Fibulák}

Két fibula fordult elő a temető leletanyagában, a 6. számú gyereksírban és a 17. számú temetkezésben. A bolygatott gyereksírban lelt fibula nem az eredeti helyén feküdt. A félkörös „fejü”, rombusz „lábú”, ékvéséssel díszített kengyelfibulák közé tartozik, aranyozott, rézötvözetből öntött példány (10. kép 6; 18. kép). Fő jellemzője, hogy a félkörös rugólemez két, egymással szembenéző spirálindával, a rombusz alakú tülemez koncentrikus, rombikus motívumokkal díszített. ${ }^{102}$

A kisméretü, öntött, háromgombos kengyelfibulák az 5. század közepe táján jelentek meg, és a század második felére voltak jellemzőek a Kárpát-medencében, a magányos sírok, kisebb sírcsoportok, és az ekkor induló nagyobb méretü temetők korai leletanyagában egyaránt. A legkorábbiak közé tartozik az ún. Bakodpuszta-típusú, láblemezén koncentrikus rombuszokkal, fejlemezén sugárirányú vésetekkel díszített variáns. ${ }^{103}$ Ezeknél későbbi gyártású a nyíregyházihoz hasonló, spirálindás kengyelfibulák ötgombos változata; jól ismert a gepida kori temetők leletanyagában, ${ }^{104}$ Cseh János a Szolnok-zagyvaparti lelőhely jó minőségü példányát az 5. sz. utolsó évtizedeire keltezte. ${ }^{105}$

A nyíregyházi darabra leginkább hasonlító fibulák - a három fejgomb, valamint a spirál- és rombuszdísz alapján a jobbágyi Petőfi utcai magányos női sírból, ${ }^{106}$ a kiszombori

${ }^{100} 32$. sír (TejRal 2005, 162).

${ }^{101}$ GubitZa 1902, 6. ábra. A Dunántúlról pl. a balatonszemesi 5. századi sírokat említhetjük, ahol a 150. sírban egy nagyobb kalcedongyöngy tekercselt ezüstkarikán feküdt a combcsontok között, övfüggő részeként (MinácZI-PÁlfi 2018, 131-132, 2. kép 4).

${ }^{102}$ KüHN 1974, 728.

${ }^{103}$ BóNA-NAGY 2002b, 120-122, Abb. 59.

${ }^{104} \mathrm{RÁCZ} 2019,77-78,12$. táblázat.

${ }^{105}$ CSEH 2005a, 27.

${ }^{106}$ Kiss Attila ezt a sírt a 6. sz. első negyedére keltezte, azonban leletanyaga alapján inkább a D3 periódus magányos női sírjai közé illeszkedik (Kiss 1981, 167-168, Taf. I, 7). 
gepida kori temető 88 . sírjából ${ }^{107}$ és Szentesről (Rákóczi út 153.) szórványleletként ismertek. ${ }^{108} \mathrm{~A}$ kiszombori az általunk tárgyalttal azonos méretű (kb. 5,8 cm) és anyagú (aranyozott rézötvözet), a szentesi és a jobbágyi aranyozott ezüstből készült, és valamivel nagyobb $(6,0$, ill. $6,3 \mathrm{~cm})$. A hasonló felépítés és díszítés mellett eltérés figyelhető meg a tülemezek végződésében: a nyíregyházi halfarokszerű, a kiszombori és a szentesi stilizált állatfejben, a jobbágyi gomba alakú motívumban végződik. A „halfarkas” végződés talán összefüggésbe hozható a kimagasló minőségű, 5. századi relief-fibulák és csatok ellentett helyzetű madárfejes nyúlványaival. ${ }^{109}$ A szóban forgó fibulák tipológiai alapon a legkorábbi, kisméretű, öntött kengyelfibulák és a valamivel nagyobb, ötgombos változatok közé illeszthetők be, gyártásuk és használatuk az 5. század második felére tehető.

A fent említettek közül a viselet módját csak a kiszombori ruhakapcsoló tü esetén ismerjük, ez az áll alatt, a nyakban helyezkedett el. A szentes-kökényzugi 66. sír háromgombos, a nyíregyházival azonos méretü kengyelfibula párja a peplos viseletnek megfelelően a két vállon feküdt. ${ }^{110}$ Ezek alapján az általunk elemzett példány tartozhatott akár a középen nyíló, akár a két vállon összefogott ruházathoz is. Amennyiben eredetileg is csak egy darab volt belöle, és a bolygatás során nem veszett el a párja, az előbbi feltételezés valószínűbb.

A temető másik fibulája a 17. számú sírban, a jobb felkar alatt jelentkezett, egy egytagú, alsóhúros, oldalt hajtott lábú vasfibula (14. kép 1). Kialakítása megfelel az ugyanerről a lelőhelyről szórványként, illetve az M3-14. lelőhely 28. épületéből előkerült, alsóhúros daraboknak. ${ }^{111}$ A ruhát a jobb vállnál foghatta össze. A Kr. u. 3-4. században szarmata területen is gyakori kisméretű, felsőhúros vasfibulák konstrukciója a római kor végén megváltozott, a D1-D2 periódustól alsóhúros példányok kerültek használatba a Kárpát-medence keleti és északi részén is. Egyszerűbb darabok településeken ${ }^{112}$ és temetkezések mellékleteiként ${ }^{113}$ is felbukkannak 5. századi kontextusban, használatuk a század második feléig követhető. A nyíregyházi fibula analógiája került elő az 5. század közepén-második felében használt Ártánd-lencsésdombi temető 9. női sírjából, ahol párban helyezkedett el. ${ }^{114}$

\section{Gyürü}

A lelőhely egyetlen, ezüstpántból készült gyürüje a 14. sírban látott napvilágot másodlagos helyzetben (13. kép 17). A gyürü feltűnően kisméretü - kisgyerek ujjára való -, két, kiszéle-

\footnotetext{
${ }^{107}$ Csallány 1961, 177, Taf. CXXXIV, 2.

${ }^{108}$ Csallány 1961, Taf. XI, 10.

${ }^{109} \mathrm{Pl}$. Szőreg-Téglagyár, 19. sír (NAGy 2005b, 183, Abb. 40).

${ }^{110}$ Csallány 1961, 35.

${ }^{111}$ Pintye 2016, 106, V. t. 5, XXV. t. 7.

${ }^{112}$ Füzesabony-Pusztaszikszói gyümölcsös (SzABó 1990, 178, Fig 4, 8), Battonya-Sziondai gyep (SzABó-Vörös 1979, 225, Fig. 9) és kvád területen is (VARsiK 2011, 204-205, Abb. 108, 1-2), mint Nitra-Párovské Háje (Pieta-Ruttkay 1997, Abb. 11, 1).

${ }^{113}$ Tiszavalk 12. sír (GARAM-VADAY 1990, 204, Abb. 15, 12), Csongrád-Kenderföldek 50. sír (PÁrducz 1959, 314, Taf. 10, 12-13), Szentes-Rákóczi F. u. 87, 2. sír (PÁrducz 1950, Taf. LXXXIII, 8).

${ }^{114}$ Mesterházy 2005, 55-56, Taf. II. 9, 2.
}

sedő végét egymásra hajlították, így zárták le és igazították az egykori tulajdonos ujjához. A fémpántból készült gyürűk rendszeresen felbukkannak az 5. századi női sírok leletanyagában, bár gyakrabban elöfordulnak azok a változatok, amelyeknél a pántgyürüt spirálisra hajlítják, vagy gyürüfejet is forrasztanak a pántra. ${ }^{115}$

\section{Ezüst lemezhüvely (tütartó?)}

A 14. sírban poncolt díszü, oldalán átlyukasztott, töredékes ezüsthenger került elö másodlagos helyzetben (13. kép 7). A tárgy párhuzama többek között Tápé-Széntéglaégető lelöhely 658. sírjának átfúrt bronzhengere, mely a sírba temetett nő medencéjénél feküdt. ${ }^{116}$ A Szeged-Csongrádi úti temető 14. sírjában a női halott térdei között átfúrt, bronzból készült henger látott napvilágot. ${ }^{117} \mathrm{~A}$ tápéi tárgy funkcióját illetően B. Tóth Ágnes feltételezi, hogy a hengert a tulajdonosa az övére függesztve hordta és tütartóként használta, noha tü nem került elő belöle, ahogy a mi esetünkben sem. ${ }^{118}$ Tüt is tartalmazott viszont a Szekszárd-palánki 217. sír hasonló, hengeres tárgya. ${ }^{119}$

A tárgytípussal kapcsolatban Tóbiás Bendegúz arra hívja fel a figyelmet, hogy az avar, alemann, illetve frank területeken gyakran tünnek fel lemezhüvelyek, amelyeket tűtartóként határoznak meg, de tüt nem tartalmaztak. Korábbi véleményekre támaszkodva ezeket a darabokat ecsethüvelyként azonosította. $^{120}$

\section{Csatok (övcsat, cipöcsat)}

Öt sírból, felnőtt és gyerektemetkezésekből egyaránt kerültek elö csatok (3., 6., 7., 17., 20. számú sír és egy szórványlelet), melyek közt három típust különböztethetünk meg.

Az első típushoz három darab csat tartozik, közös jellemzőjük, hogy ovális, lemezes, három szegeccsel ellátott csattest kapcsolódik az ugyancsak ovális csatkarikához. Az e csoportba tartozó csatok jellemzően bronzból vagy ezüstből készültek. Az egyik ovális testü bronzcsat a 6. számú gyereksírban feküdt, másodlagos helyzetben (10. kép 3; 19. kép 3). Mérete alapján övcsat lehetett, masszív, lehajló oldalú példány. A másik két csat ezüstből készült, kettős lemezü, és a 3. sírban kerültek feltárásra (9. kép 1-2; 19. kép 1-2). A nagyobb, amely a jobb combcsont felső végénél volt, övcsat, a kisebb méretü, jobb lábfejnél fekvő cipőcsat lehetett. A csatok párhuzamai kerültek elő a Mezőkövesd-mocsolyási 2. sírban, amelyeknek mérete és síron belüli elhelyezkedése is

${ }^{115}$ A spirálos gyürük gyűjtése a Hajdúnánás-fürj-halom-dűlői 247. sír gyürüje kapcsán: Rácz 2019, 76. Pántgyürü fejjel pl.: Kapolcs 1. sír (Cs. Dax 1980, 98), Szolnok-Zagyvapart 17. sír (férfi sír, CSEH 2005a, 21).

${ }^{116}$ B. Tóтн 1994, 295, további párhuzamokkal római császárkori lelöhelyekröl is.

${ }^{117}$ VöRös 1981, 122.

${ }^{118}$ B. Тótн 1994, 296.

${ }^{119}$ Kiss 1996, 55-57. Ld. még az 5. századi leletekkel kapcsolatban: Hajdúnánás-Fürj-halom-dủlő 441. sír (RÁcz 2019, 95).

${ }^{120}$ Tóbiás 2007, 333. Ld. még Brown 1974. 
hasonló volt. ${ }^{121}$ További analógiákat említhetünk például Viminacium-Burdelj (Kostolac) lelőhely két sírjából, ${ }^{122}$ Vác környékéről, ${ }^{123}$ Kisterenyéről, ${ }^{124}$ illetve a Mezőkövesd-mocsolyási 1. sírból is. ${ }^{125}$ A 3. sír övcsatján, a csattüske tövénél három bordadísz található, hasonlóan az előbb említett mezőkövesdi sír öv- és cipőcsatjaihoz. ${ }^{126}$

E csatok keltezése szempontjából fontos adalék, hogy a csépáni (Cepari) magányos temetkezésben soliduslelettel együtt került elő hasonló, ovális testű aranycsat. A 430-441 között készült, konstantinápolyi veret ${ }^{127}$ alapján ezt a temetkezést a D2/D3 időszakra, az 5. század középső harmadára keltezhetjük. Ez az adat jól illeszkedik az általunk tárgyalt temető 14. sírjának érmeleletéhez (III. Valentinianus siliqua, 425-455 közötti veret).

A második csattípust egy vese alakú csat képviseli, amely szórványként került elő a temető területén (171. str. számon, 15. kép). Ez a forma kifejezetten 5. századi jellegzetesség, az egyszerü csatok mellett előfordul polikróm díszítésü tárgyként és csontból kifaragva is. A legközelebbi ismert analógia egy Nagykálló határában feltárt hun kori magányos sírból származik. ${ }^{128}$

A harmadik típusba egyszerü, ovális karikájú vascsatok tartoznak (7. és 17. sír: 11. kép 2; 14. kép 2). E csatok mind a hun korban, mind az 5. század második felében igen elterjedtek voltak, ${ }^{129}$ és a gepida kori temetők feltárása során is nagy számban kerültek elő. ${ }^{130}$ A térségben fekvő lelőhelyek közül például Nyíregyháza-Rozsrétszőlőből ismert hasonló csat. ${ }^{131} \mathrm{~A}$ fentieken kívül a 20 . sírban is volt egy vastöredék, ami eredetileg csathoz tartozhatott.

\section{Fésúk}

A nyíregyházi temetőben két sírból került elő fésü, a 2. számú gyereksírból és a 14. számú, feltételezett gyermektemetkezésből. A fésű a 4. század utolsó harmadától kezdve

${ }^{121}$ Lovász 1999, 239; Lovász 2005, 53.

${ }^{122} 15$. sír, övcsat férfisírból; 50 . sír, cipőcsatok férfi sírból. IVANišEvić et al. 2006, Pl. 3, Pl. 8. Mindkét sírt a temető B fázisába sorolják, az 5. sz. középső harmadától a 6. sz. elejéig (IvANišEvić et al. 2006, 129).

${ }^{123}$ Csallány 1961, 233, Taf. CCII, 15

${ }^{124}$ Csallány 1961, Taf. CCXXVI, 1.

${ }^{125}$ LovÁsz 2005, 50.

${ }^{126} \mathrm{~A}$ fenti, ovális testű csatok gravírozott-poncolt, néha görög feliratokkal ellátott, öntéssel készült változatait a nemzetközi szakirodalom Bône-Csongrád-típusú csatokként említi. Ezek a mediterrán térség keleti részén, illetve a Fekete-tenger partvidékén készültek, és az 5. század középső és 3. harmadára jellemzőek. Magyarország területéről Csongrád-Kettőshalmi-dűlőből (?) ismert hasonló, keresztény szimbólumokkal ellátott, import darab (Csallány 1961, 225, Taf. CCXI, 10; Tóth et al. 2016, V/70, 266. további irodalommal).

${ }^{127}$ Somogyi 2019, 609-610, Abb. 3.

${ }^{128}$ Pintye 2018a, 297, 305, 4. kép 1.

${ }^{129}$ SimONYi 1999, 74.

${ }^{130}$ Például Hómezővásárhely-Kishomokon: BóNA-NAGY 2002b, Taf. IX, 22, Taf. XII, 2, Taf. XVI, 1, Taf. XVI, 3, Taf. XXIV, 1.

${ }^{131}$ Pintye 2014, 113, 7. kép 5. gyakori sírmellékletnek számít a Kárpát-medencében, népszerüsége az Alföldön a gepida időszakban érte el csúcspontját, akár 30-50\%-os előfordulási arányt mutatva egyes temetkező helyeken. ${ }^{132}$

A 2. sír fésűje kétsoros, háromrészes agancsfésü, amely másodlagos helyzetben került elő (8. kép 1). A késő római eredetü kétsoros fésü egyaránt népszerü volt a késő császárkorban, valamint a hun és a gepida időszakban is, ez utóbbiban már a temetők leggyakoribb tárgytípusának számít. ${ }^{133}$

A 14. számú sír fésüje ugyancsak bolygatott részen feküdt. ${ }^{134}$ Egy ritkábban előforduló típusba tartozik: fogólemeze harang alakú, ${ }^{135}$ pereme mentén pontkörsorral díszítették (13. kép 14; 20. kép). A jellegzetes fogólemezű variáns Pannoniában és a Marosszentanna-Csernyahov kultúra területén is jól ismert, azonban csak néhány darab került elő a Dunától keletre fekvő Barbaricumban. ${ }^{136}$ A pontkörsoros díszítés ugyanezekre a területekre jellemző. ${ }^{137}$ A nyíregyházi példány fogólemeze keskenyebb, mint a valamivel korábbi, „Marosszentanna-típusú" fésüké. ${ }^{138}$ A forma és a pontkörös díszítés szempontjából is közeli párhuzamnak számít egy szilvásváradi magányos sír fésűlelete, amely az itt előkerült import edény- és gyöngylelet, valamint a cikádafibula alapján az 5. század középső harmadára keltezhető. ${ }^{139}$ Hasonló, pontkördíszes fésüt ismerünk hun kori vagy közvetlenül a hun kor utánra keltezhető magányos sírokból Tiszalök-Rázompusztáról $^{140}$ és Hernádcsányból (Čaňa) is. ${ }^{141}$

\section{Edénymellékletek}

\section{Üvegedény}

A nyíregyházi temető sírjaiban öt esetben fordult elö üvegedény, összesen négy pohár (3., 6., 14., 18. és 19. sír, az utóbbi két sír töredékei valószínűleg összetartoznak, és a bolygatás során kerültek a szorosan egymás mellett fekvő sírokba, szétszórva). A Kárpát-medencei népvándorlás kori üvegleleteket

\footnotetext{
${ }^{132}$ Nagy 2004, 144; RÁcz 2016, 309-310.

${ }^{133}$ Pintye 2009; Masek 2016, 106-113; Bóna-Nagy 2002b, 95-98.

${ }^{134} \mathrm{~A}$ fésű a sír nyugati végébe összehúzott csontok között került elő. Miután eredetileg ez volt a sír fej felőli vége, elképzelhető, hogy a fésüt az elhunyt feje mellé helyezték.

${ }^{135}$ Ld. Bózsa Anikó doktori disszertációjának tipológiai beosztását, II.1.1.1c típus: BózsA 2016, 142-143.

${ }^{136} \mathrm{~A}$ „púposhátú” csontfésűk Pannoniában a 4. század második felében tüntek fel, illetve a Marosszentanna-Csernyahov-kultúra területén az 5. század közepéig használatban voltak (PINTYE 2009, 166, 177).

${ }^{137}$ T. Bíró Mária megjegyzése szerint a pontkörös minta a kétsoros, háromszög alakú, félköríves és púposhátú csontfésüknél mind megtalálható (T. Bíró 2002, 59. Ld. még MASEK 2016, 138-139).

${ }^{138}$ A fésűtípust legutóbb Masek Zsófia tárgyalta kimerítően: MASEK 2016, 127-131.

${ }^{139}$ GulYÁs et al. 2019, 442-443.

${ }^{140}$ Harang alakú fogójú példány (PÁrducz 1959, 330, Taf. XXII, 3).

${ }^{141}$ Félkörös fogójú fésű vonal és pontkördíszítéssel. Ezt, a nyíregyházinál szélesebb fogójú példányt Jaroslav Tejral a D2 periódusba (380/400-440/450) helyezte (TejRal 1997, 345, Abb. 21, 11; 351).
} 

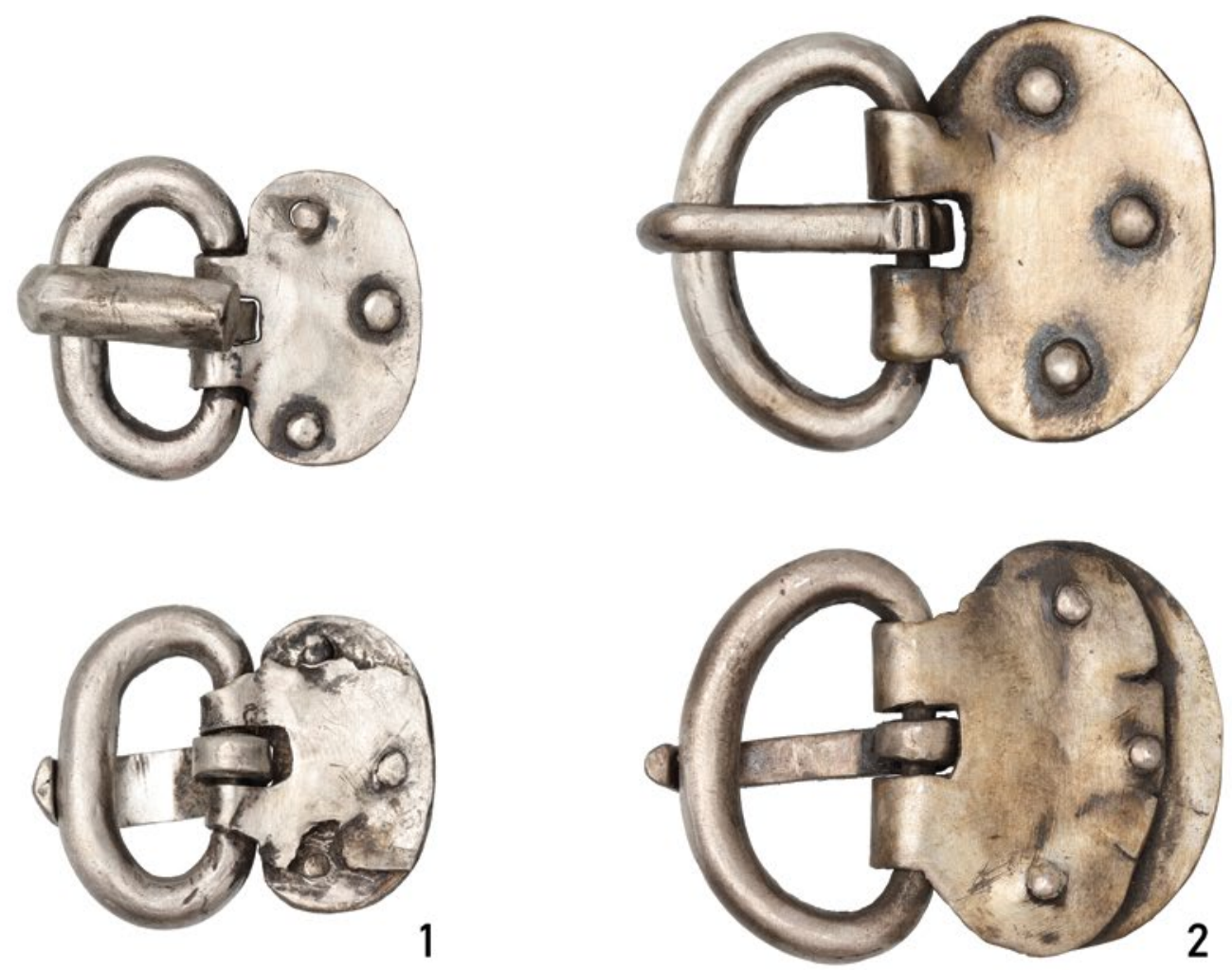

$5 \mathrm{~cm}$
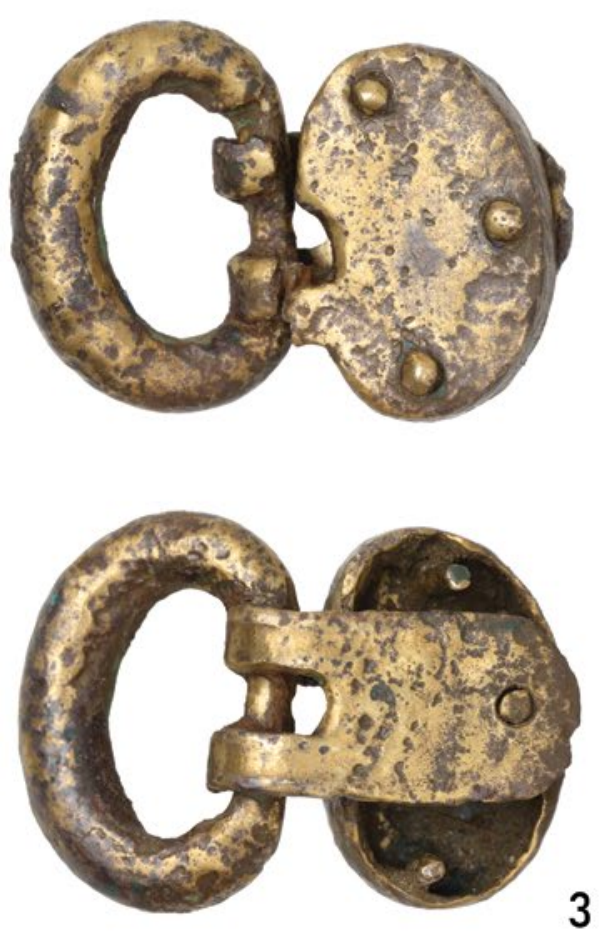

19. kép. M3-58. lelöhely: öv- és cipőcsatok. 1-2: 3. sír; 3: 6. sír

Fig. 19. Site M3-58: belt and shoe buckles. 1-2: Grave 3; 3: Grave 6 


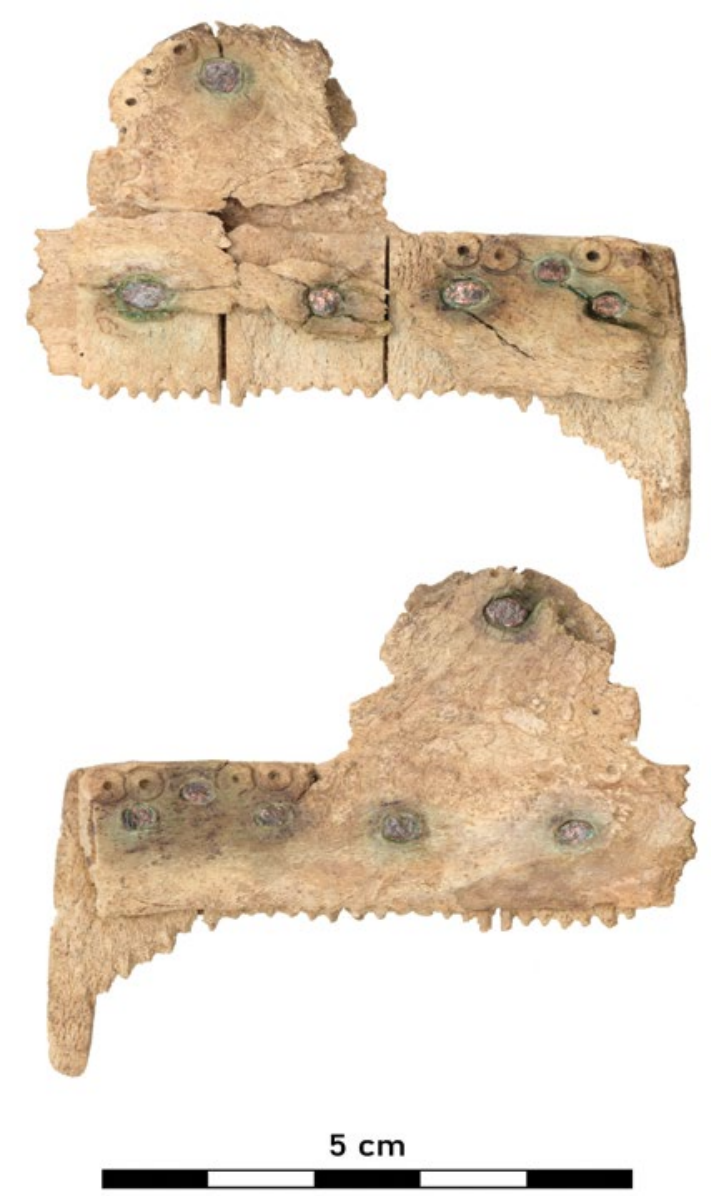

20. kép. M3-58. lelőhely: fésű a 14 . sírból

Fig. 20. Site M3-58: comb from Grave 14

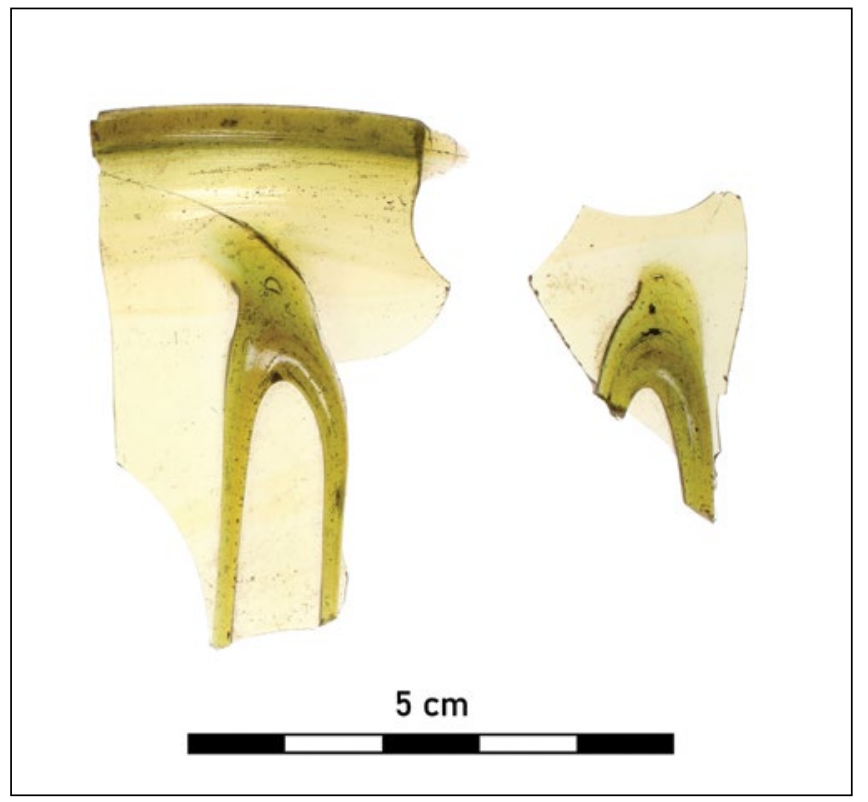

21. kép. M3-58. lelőhely: üvegpohár a 3. sírból

Fig. 21. Site M3-58: glass cup from Grave 3 teljességre törekvő módon elsőként Kiss Attila gyüjtötte öszsze és elemezte egy rövid tanulmányban, ${ }^{142}$ majd Varga Zsóka tárgyalta kimerítően 2016-os szakdolgozatában. ${ }^{143}$ Ezeken kívül Dévai Kata pannoniai késő római üvegleletekről szóló doktori disszertációja szolgál jó kiindulópontként e tárgyak meghatározásához. ${ }^{144}$ A gepida korból Cseh János a kengyeli telep üvegleleteinek közlésekor gyüjtött össze 16 lelöhelyet, ahol üvegpoharak kerültek elö. ${ }^{145}$

A nyíregyházi temetőben feltárt üvegedények eltérnek a pannoniai, késő római üveggyártás hagyományaitól. Valamennyi pohár melegen lekerekített peremü, szemben a Pannoniára jellemző levágott peremmel, és a 6 . sír edényének kobaltkék színe is szokatlan ebben az időben. A többi edény olívazöld árnyalata megfelel a korszakban gyakran alkalmazott, vas-, mangán- és titántartalmú, ún. HIMT üvegeknek.

A 3. és a 18-19. sír üvegpoharai Ulf Näsman tipológiája alapján az Eketorp 8-as csoportba, Kiss Attila rendszere szerint pedig az ún. E-típusba sorolhatók be (9. kép 3; 15. kép 2; 21. kép; 24. kép). ${ }^{146} \mathrm{~A} 18$. és 19. sír üvegtöredékei valószínüleg egy edény részei. ${ }^{147} \mathrm{Az}$ e csoportba tartozó üvegtárgyak közös jellemzője a harang alakú test, a nagyméretü, függőleges, ovális, vagy hullámvonalat formázó üvegszálas rátétdísz és a kis, korong alakú talpgyürü. A nyíregyházi poharak esetében bizonytalan a díszítés, illetve a talp teljes rekonstrukciója, mert a tárgyak alsó része hiányzik. Ez a fajta rátétdísz késő római hagyományra utal, amely egyaránt megtalálható volt a nyugati provinciákban és a Pontus-vidékén is. ${ }^{148}$ Ugyanakkor a hasonló formájú és díszítésü késő császárkori, Germania Libera területéről származó előzmények esetén H. J. Eggers megjegyzi, hogy a nyugati provinciákból nem ismertek hasonló poharak, és valószínüleg a Római Birodalom egy keleti centrumában készültek. ${ }^{149}$ A két nyíregyházi pohárnak több párhuzama ismert a Kárpát-medencéből, elsősorban az észak-keleti területekről: Barabás-Bagolyvárról, ${ }^{150}$ Gencs/ Ghenci-Akasztódombról, ${ }^{151}$ Tarnaméra-Urak-dülőjéről, ${ }^{152}$ Kapi/Kapušanyból (1940), ${ }^{153}$ Perse/Pršaból ${ }^{154}$ származik hasonló lelet. Bóna István a Barabás-bagolyvári leletet a hun kor végére, a 450-460 körüli időszakra keltezte. ${ }^{155}$

\footnotetext{
${ }^{142}$ KIss 1999.

${ }^{143}$ VARGa 2016. zéséhez nyújtott segítséget!

${ }^{145}$ CseH 1999, 25-27.

${ }^{146}$ KIss 1999, 237. színüleg a harang alakú pohár részei ezek is.

${ }^{148}$ NäSMAN 1984, 146.

${ }^{149}$ EgGers 1951, 61, Taf. 14, 189-195, Karte 51-52.

${ }^{150}$ Kiss 1999, 226; BónA 2002a, 18, Taf. I, 4.

${ }^{151}$ NÉMETi 1967, 506, Abb. 5; Kiss 1999, 223.

${ }^{152}$ BónA-SzABó 2002, 241, Taf. LVIII, 1.

${ }^{153}$ BUDINSKÝ-KRIČKA 1957, 358.

${ }^{154}$ Werner 1959, 427, Abb. 4.

${ }^{155}$ BóNA 2002a, 21.
}

${ }^{144}$ DÉvAI 2012. Ezúton is köszönjük Dévai Katának az üvegek elem-

${ }^{147} \mathrm{~A}$ 18. és 19. sírban az összeilleszthető perem- és oldaltöredékek mellett további, részben összeilleszthető oldaltöredékek is előkerültek (7, illetve 8 darab), amelyek anyaguk és színük alapján egyazon, hosszanti rátétdíszes üvegpohárhoz tartoztak: való- 
A 6. számú sírban, a sír nyugati részén kobaltkék üvegpohár töredékei feküdtek két kerámiaedény közelében (10. kép 9; 22. kép). A tárgy a féltojás alakú poharak csoportjába tartozik, melyeket a 4. század második felétől kezdve gyártották mind a keleti, mind a nyugati római tartományokban, és nagy népszerűségnek örvendtek a Barbaricumban az 5. század folyamán. ${ }^{156}$ Ugyanakkor a kobaltkék árnyalat szokatlan ebben az időszakban; Varga Zsóka gyűjtése alapján Kapi/Kapušanyban (1939) fordult még elő sötétkék, féltojás alakú üvegpohár. ${ }^{157}$ $\mathrm{Az}$ általunk tárgyalt temetöhöz közeli 14. számú lelöhely - településrészlet - 39. objektumában is előkerült egy kisméretű, kobaltkék üvegtöredék, amely szintén e pohártípusba tartozhat. ${ }^{158}$

A 14. sír üvegpohara az erősen megbolygatott sír délnyugati részéről került elő, töredékes állapotban (13. kép 2; 20. kép). Bizonytalan, hogy milyen lehetett az eredeti formája, de színe és díszítése alapján valószínűleg az Eketorp 2-es típusba sorolható be. A csoport jellegzetessége a pohárral megegyező színű vonalból, illetve körökből álló minta. Ez utóbbi a pohár oldalán vízszintesen fut körbe, a kisebb körök sorozatát egy-egy nagyobb kör szakíthatja meg. Az általunk vizsgált tárgy oldaltöredékein is díszítés látszik: plasztikus borda, alatta két helyen kis formába nyomott, hosszúkás, ovális/csepp alakú motívum. A pohártípus nem gyakori a barbaricumi területeken, de általánosan előfordul a Nyugatrómai Birodalom provinciáiban a 4 . század végén és az 5. század elején. ${ }^{159}$

\section{Kerámia}

$\mathrm{Az}$ üvegedényeken kívül a temetőben két sírból került elő mellékletként kerámia. A 6. sír délnyugati sarkában, az üvegpohár mellett egy Murga-típusú korsó volt elhelyezve (10. kép 1; 25. kép 2). A korsótípus a Közép-Duna-vidék hun kori temetkezéseinek egyik legjellemzőbb edénymelléklete. ${ }^{160}$ A nyíregyházi darab talpa korongon eldolgozott, felülete simított, a perem alatt és a hason vízszintesen fényezett. A kelet-magyarországi nyakpárnás korsók újabb összefogla-

\footnotetext{
${ }^{156}$ Kiss 1999, 238, „A” típusként. Ld. még Sorokina 1970; BARKóCZI 1988, 37a-b.

${ }^{157}$ VARGA 2016, 21. sz.; BudinSKY-KRICKA 1957, 356; illetve Mezöszemere-Kismari-fenék 3 sírjából (29., 30., 35. sír) említenek még egy-egy kúpos testü, kékes, de inkább vízszínü poharat (VARGA 2016, 33., 34., 54. sZ.; VADAY-DomboróczKi 2001, 11, 13, 16). Meg kell még jegyeznünk, hogy a 4 . század végi - 5. századi poharakon díszítésként nagyon elterjedt a kék szín, de inkább az opak sötétkék alkalmazása, nem pedig ez a valamivel világosabb és áttetsző változat.

${ }^{158}$ Pintye 2016, 106, XII. t. 3. Pintye Gábor Mainz-Weisenauból említ párhuzamot e darabhoz (KLEIN 1999, 9, Abb. 14).

${ }^{159}$ NäSMAN 1984.

${ }^{160}$ AlföLdi 1932, 43-46; PÁRdUCZ 1959, 357-358.
}

lása szerint az alsó harmadban hasasodó, Ia formatípusba sorolható, technológiai jegyei a késő szarmata edényművességhez állnak közel. ${ }^{161}$ Jó párhuzama a szomszédos 14 . lelőhely egyik gödréből került elő. ${ }^{162}$ Közeli analógia továbbá a Kisvárda-daruszigeti, a D1-D2 periódusba datált sírban és a Csongrád-kenderföldeki temetőben lelhető fel, ${ }^{163}$ díszítése pedig egy körösladányi, nagyobb méretü korsóval rokon. ${ }^{164}$ A Murga-típusú korsók sírba helyezése egészen a 6. század első feléig megfigyelhető, ${ }^{165}$ a hun kor korai évtizedeiben feltünő, nagyméretü edények ${ }^{166}$ helyett idővel egyre kisebb ürtartalmú, a nyíregyházihoz hasonló méretü korsók kerültek a halott mellé.

A 6. sír nyugati falánál, az üvegpohár-töredékek és a Murga-típusú korsó mellöl egy gömbös testü edény is előkerült (10. kép 2; 25. kép 1). A szemcsés kisfazék erősen hasasodó, nyomott testü, szögben törő alján a korongolás nyomait eldolgozták, levágás vagy késsel levagdalás nem figyelhető meg rajta. Igen hasonló fazék töredéke volt a 9. sírban is (11. kép 1). Az átlagos méretü fazekak mellett az 5. század közepétől kezdve a kisméretű darabok használata is megfigyelhető a településeken, a nyúlánkabb, hengeres, gepida kori formák helyett ekkor még szélesebb darabok jellemzőek. ${ }^{167}$ A kisméretü, gömbölyü, szemcsés edénykék sírmellékletként a gepida temetőkben is gyakoriak maradtak. ${ }^{168}$ A nyíregyházi kisfazekak pontos kronológiai jegyekkel nem bírnak, az alj levagdalásának hiánya alapján azonban a 6. század előtt készülhettek.

\section{Érmék}

A nyíregyházi temetőben két ezüstérme került elő a 14. sírból. Az első érem a 2. században készült: Marcus Aurelius császár erősen korrodált denárja (13. kép 21). ${ }^{169}$ A második egy 422-455 között vert III. Valentinianus siliqua, amely töredékes, és két átfúrt lyukkal látták el (13. kép 30). ${ }^{170}$ Míg az elöbbi nem alkalmas kronológiai megállapításokra, ez utóbbi ezüstpénz fontos terminus post quem adatot szolgáltat a sír és

${ }^{161}$ MaseK 2013, 245, Abb. 4.

${ }^{162} \mathrm{~A}$ 39. sz. jelenség, melyből a kék üvegpohár töredékei is ismertek (Pintye 2016, XII. t. 1.). Ez alátámasztja a 6. számú sír és a település közvetlen kapcsolatát.

${ }^{163}$ Németh 1988, 219-222, Kat. V, 5. e; PÁrducz 1959, Taf. XVI, 1.

${ }^{164}$ Tejral 2007, Abb. 13, 9; Masek 2013, Abb. 5, 1.

${ }^{165}$ MaseK 2013, Kat. 61, Tab. 1.

${ }^{166}$ Soós et al. 2017, 53-54, Fig. 5.

${ }^{167}$ Ártánd (B. Tóth 2006, 97, Abb. 27); Hernádvécse (Soós et al. 2017, Pl. XVI, 6).

${ }^{168}$ Nagy 2004, 163-164, 27. kép 5; Szentes-Kökényzug (CsALLÁNY 1961, Taf. XX, 13).

${ }^{169}$ Ezúton szeretnénk megköszönni Torbágyi Melindának és Somogyi Péternek az érmék meghatározását.

Róma 170-171, RIC 251. A.: )INVS - AVG TRP(, babérkoszorús fej j. R.: császár tógában oltárnál áldoz.

${ }^{170}$ Trier 425-455. RIC 2102 szalagdiadémos fej j. A.: DN VALENTINI[ANVS PF A]VG. R.: [V]RTVS [ROM]ANOR[VM] b. néző Róma ül curulisi széken j. Victoriát, b. hosszú keresztet tart, b. mezőben * 


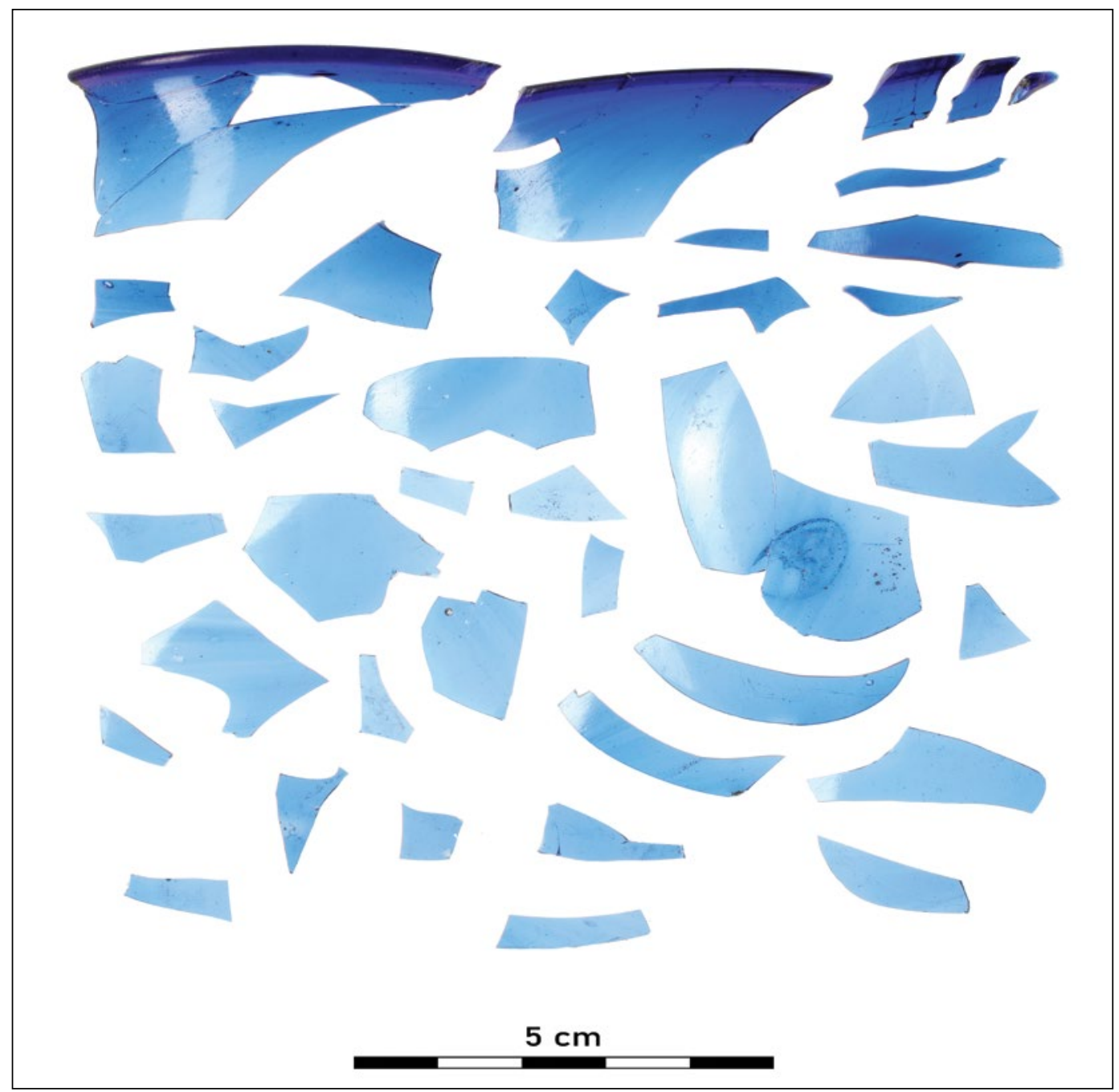

22. kép. M3-58. Ielőhely: üvegpohár a 6. sírból

Fig. 22. Site M3-58: glass cup from Grave 6

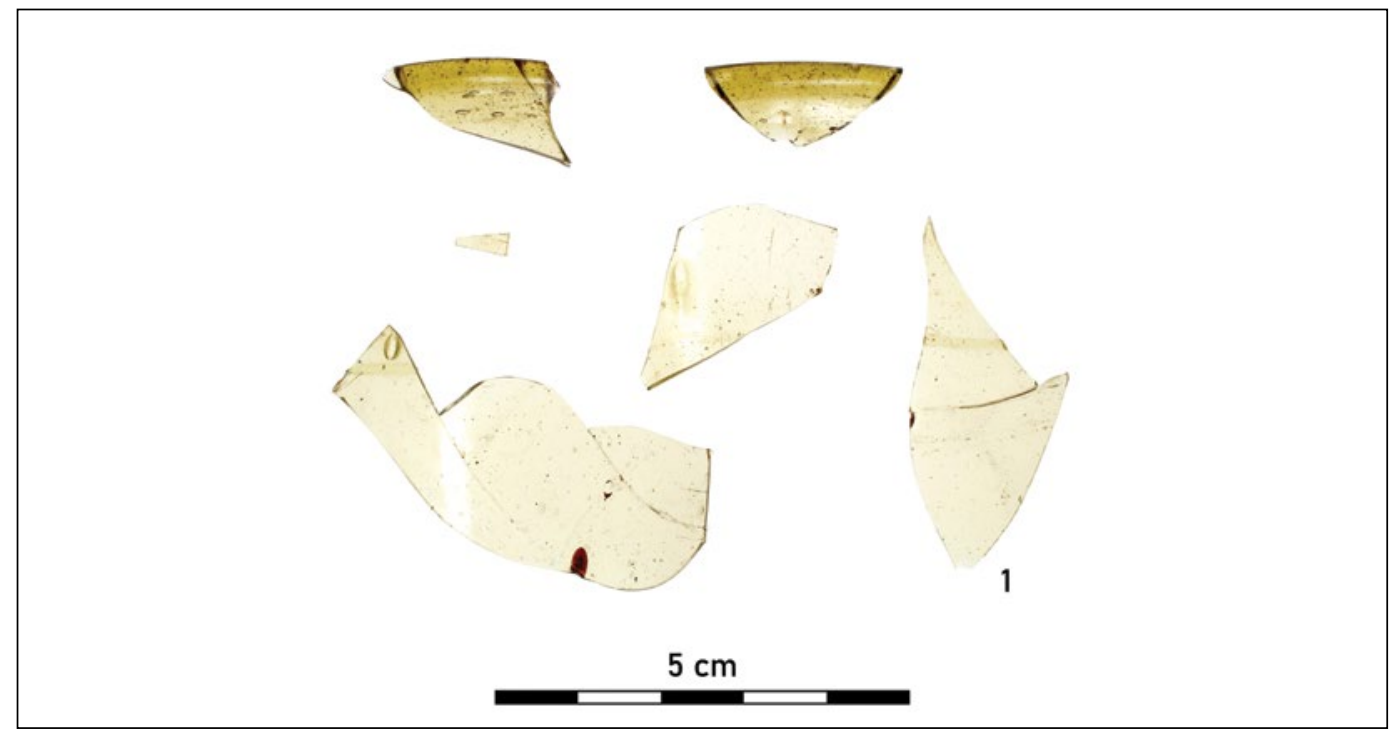

23. kép. M3-58. lelóhely: üvegpohár a 14. sírból

Fig. 23. Site M3-58: glass cup from Grave 14 

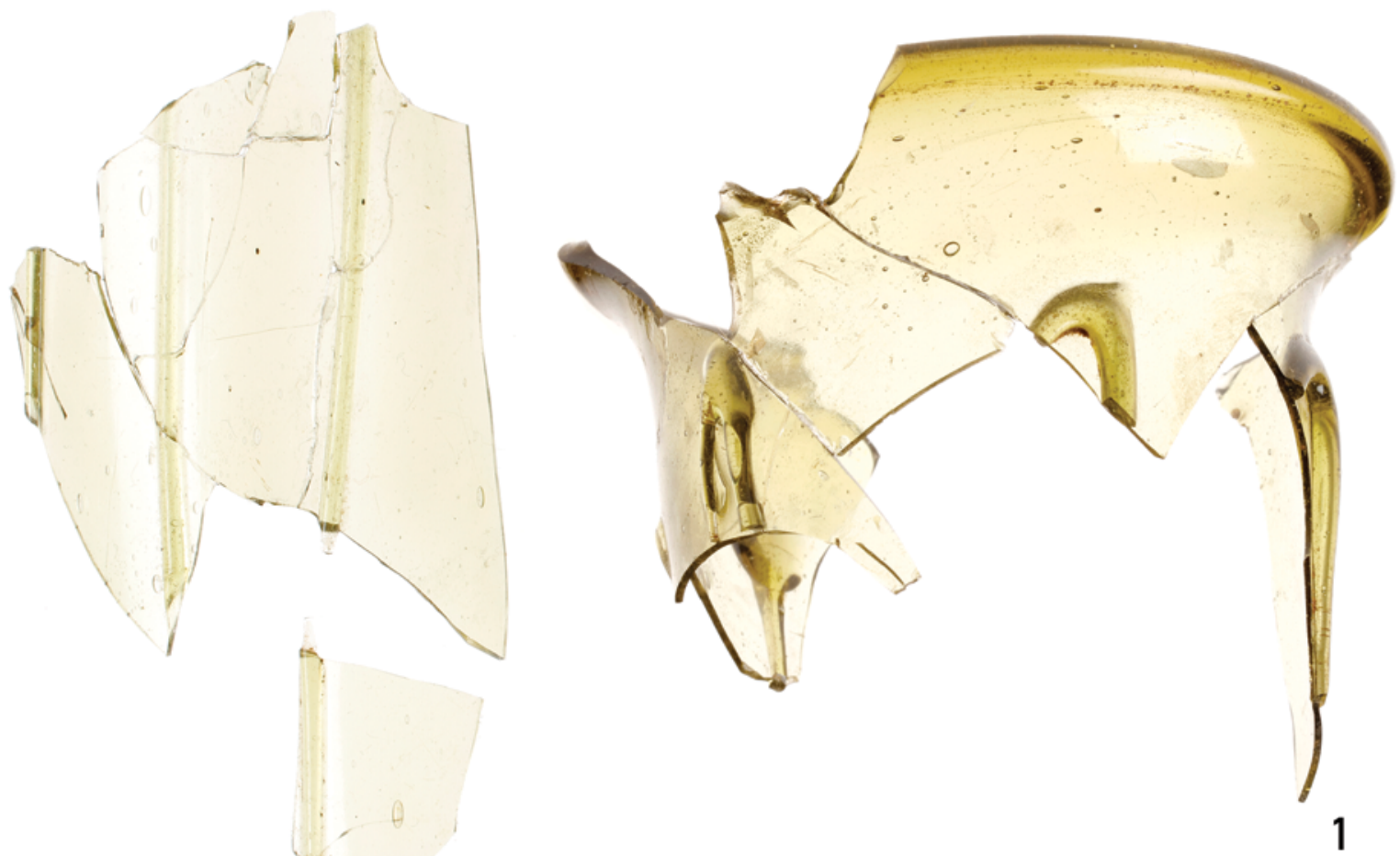

2

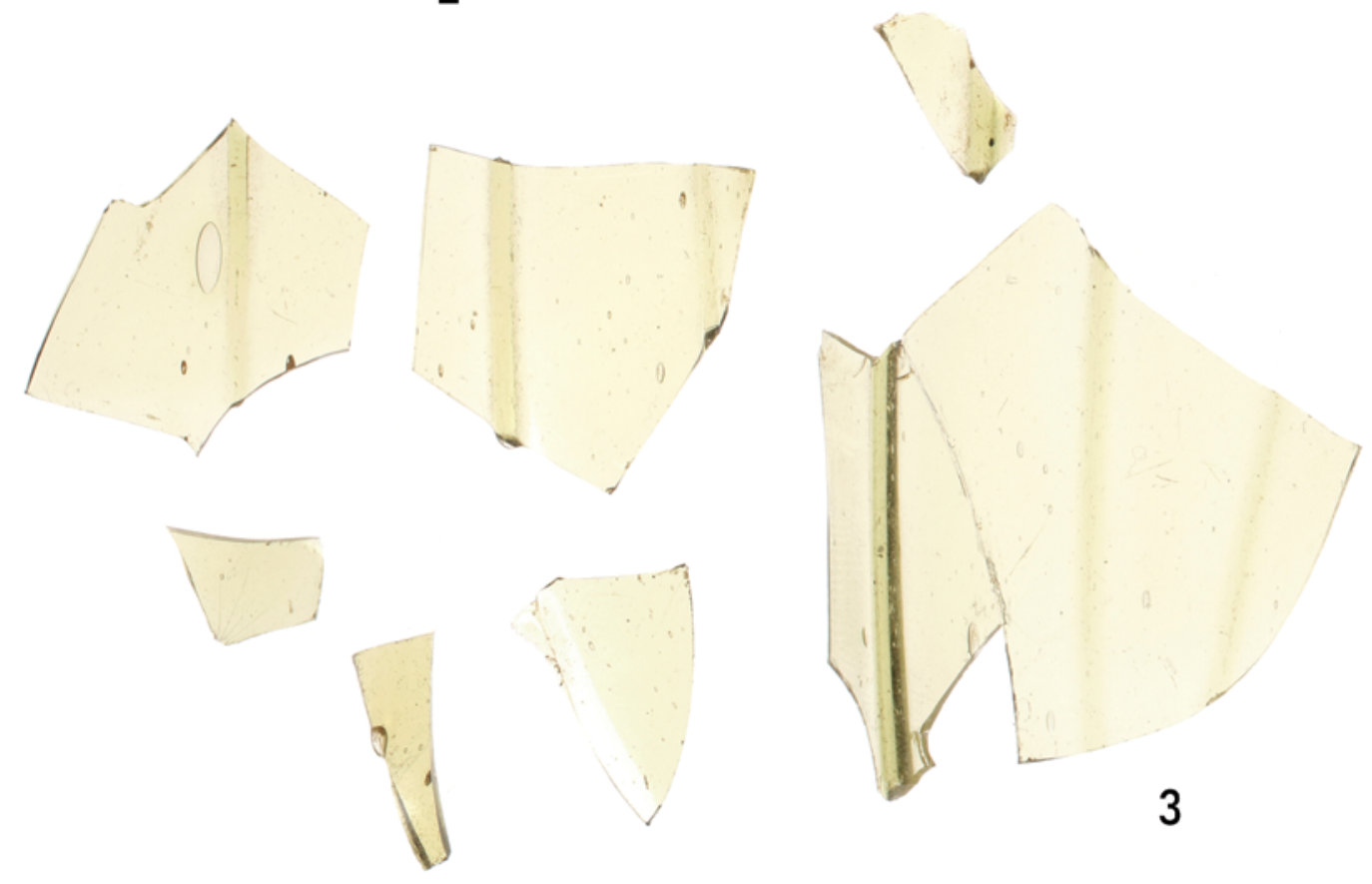

$5 \mathrm{~cm}$

24. kép. M3-58. lelőhely: üvegpohár a 18-19. sírból

Fig. 24. Site M3-58: glass cup from Grave 18-19 

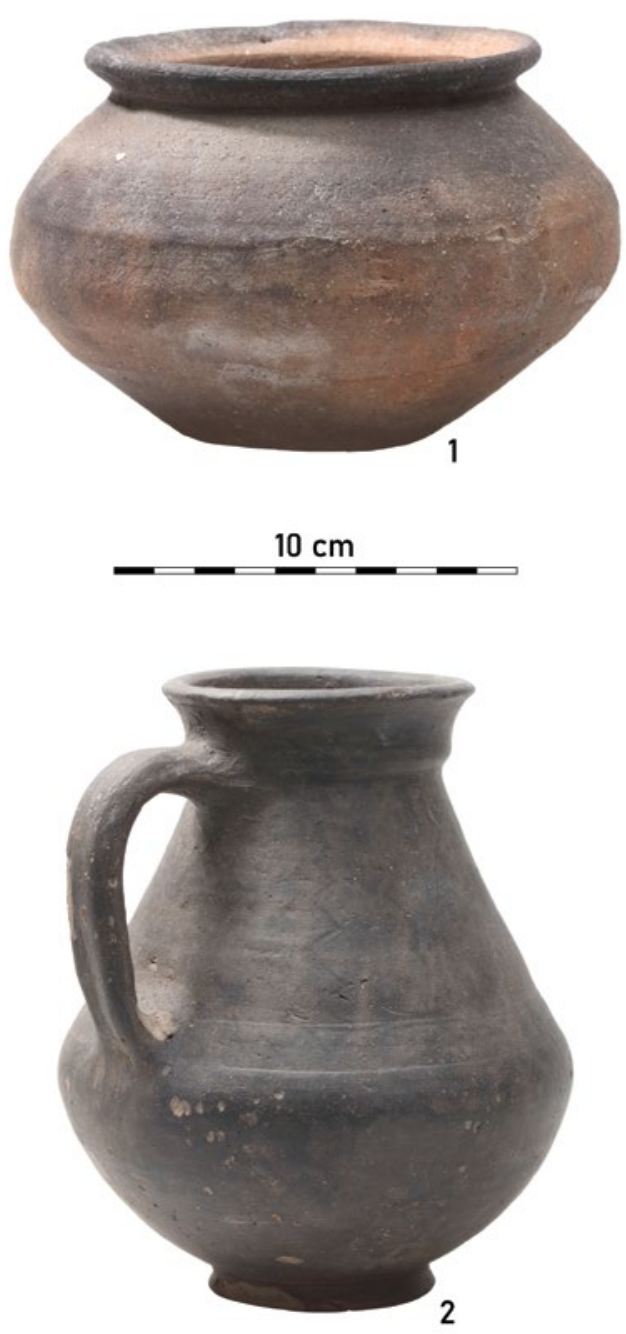

25. kép. M3-58. lelőhely: kerámiaedények a 6 . sírból

Fig. 25. Site M3-58: ceramic vessels from Grave 6

- a lelőhely kis mérete, rövid használati ideje okán - az egész temető és település keltezéséhez.

$\mathrm{Az}$ 5. századi sírokban csak ritkán kerülnek elő érmék, legyen szó akár korábbi római, akár kortárs pénzekről. ${ }^{171} \mathrm{Az}$ 5. század első felében készült solidust ismerünk a csépáni (Cepari), az érmihályfalvi (Valea lui Mihai) ${ }^{172}$ és a bácsordasi (Karavukovo), a D2/D3 időszakra tehető magányos temetkezésekből. ${ }^{173} \mathrm{~A}$ nyíregyházi érmék eredeti, sírbeli helyzete a bolygatás miatt nem ismert. A III. Valentinianus siliquát

\footnotetext{
${ }^{171}$ Összefoglalóan az 5-6. századi, a Kárpát-medence keleti feléből származó sírok és szórványleletek római és bizánci érmeleleteiről: Csallány 1961, 291-293. Az általa felsorolt érmék között van néhány ezüstpénz, illetve átfúrt, gyöngyök közt viselt érme is. A gepidának tartott temetkezések bizánci érmeiről: Somogyi 2019.

${ }^{172}$ Somogyi 2019, 609-610, Abb. 3 és 612, Abb. 7.

${ }^{173}$ CSALLÁNy 1961, 230.
}

tulajdonosa felfüzve ékszerként vagy amulettként hordhatta, akár az ugyanebből a sírból származó gyöngyökből füzött gyöngysor részeként. Különleges amuletteket több ízben is megfigyeltek 5. századi gyermektemetkezésekben. ${ }^{174}$

\section{ÖSSZEFOGLALÁS}

\section{Kronológia, életmód és az M3-58. lelőhely kapcsolata a Nyíregyháza környéki 5. századi településekkel és temetőkkel}

Nyíregyháza-Csorda-Páskum II. (M3-58. lelőhely) 20092010-ben napvilágra került 5. századi településrészlete egy egységet alkot a 2011-ben Pintye Gábor által feltárt, és már korábban publikált lelőhelyrésszel. ${ }^{175}$ Mindezt megerősíti az épületek hasonló, középszelemenes szerkezete, de a töredékes kerámiaanyag egyező technológiai és formai összetétele is. ${ }^{176}$

A lelőhely telepjelenségei - kronológiailag érzékenyebb tárgytípusok híján - csupán tág határok közt keltezhetőek. A kerámia típusai a Felső-Tisza vidékről eddig közzétett, 5. századi települések leleteivel mutatnak kapcsolatot. Nyíregyházán azonban hiányzik a római importáru, valamint azok a finom, jó minőségü, késő provinciális műhelyhatást mutató darabok is, melyek több, az 5. század közepe előtt indított lelöhelyen, mint Hernádvécse, Sajószentpéter vagy a rákóczifalvi telep 2 . horizontja, megfigyelhetőek. ${ }^{177}$ A kisebb méretű korsót, a bögrét és a fazekakat is a későbbi, gepida kézművességben továbbélő formáknak tarthatjuk, ${ }^{178}$ de a lelőhelyen nincs arra utaló lelet, hogy a település megérte volna a 6. századot. Mindez összecseng Pintye Gábor datálásával is, aki egy vastag karikájú bronzcsat alapján az általa feltárt településrészt az 5 . század második felére helyezte. ${ }^{179}$

A település szomszédságában fekvő, teljes egészében feltárt temető használata az 5 . század középső harmadában kezdődhetett meg. A 14. sírban lelt III. Valentinianus siliqua az 5. század második negyedét jelöli ki terminus post quem adatnak. A D2/D3 periódusra, az 5. század közepére utalnak a 3. sír ovális ezüstcsatjai, a 3. és a 18. sír üvegpoharai és a 14. sír harang alakú fogólemezes fésűje is. Más leletek, mint a 6. sír háromgombos kengyelfibulája, inkább az 5. század második felére keltezhetőek. Egyértelműen a 6. századra tehető tárgytípus azonban nem fordult elő a temetőben. Az egész

\footnotetext{
${ }^{174}$ NAGY 2005a; RÁCZ-DARÓCZI-SZABó 2016.

${ }^{175}$ Pintye 2016.

${ }^{176}$ Pintye 2016, 107.

${ }^{177}$ MaseK 2018, 257.

${ }^{178}$ Szintén az 5. századi keltezést erősítheti meg a szemcsés fazekak peremátméröje, mely lelőhelyünkön $15-16 \mathrm{~cm}$, míg a 6 . századi gepida telepek fazekai átlagosan nem haladják meg a $15 \mathrm{~cm}$-t. Az M3-58. lelőhely edényarányai így inkább az 5. század középső harmadában induló ártándi lelöhely nagyobb fazekaival mutatnak rokonságot (B. Тóтн 2006, 121, Abb. 31; MASEK 2018, 255, 175. kép).

${ }^{179}$ Pintye 2016, 107.
} 
leletanyag jellege - szíjszorító lemezes csatok, nagyméretű, borostyánból készült és díszített üveggyöngyök, drótra füzött csüngődíszek, üvegedények és Murga-típusú korsó - a D2/ D3 és D3 periódus kis sírszámú temetkezőhelyeit és magányos sírjait ${ }^{180}$ idézi és nem a nagyobb méretű, a 6 . században is használt gepida kori temetőket. Párhuzamul hozhatjuk Nyíregyháza-Stadion lelőhely szórványleleteit is, ahol borostyángyöngy, folyatott díszü gyöngy és csengő került elő együtt, akárcsak az általunk tárgyalt esetben. ${ }^{181}$ A temetkezési szokások közül kiemelendő az üvegpohár mellékletek gyakorisága (négy eset), valamint az edénykészlet sírba helyezése (6. sír), ami római mintára elterjedő hun kori hagyományt őriz, a viseleti tárgyak közül pedig az üveggyöngyökkel és fém tartozékokkal díszített öltözet, amely három gyerek-, illetve feltételezhető gyereksírban fordult elő.

A fentiek alapján az M3-58. lelőhelyen feltárt temető és településrészlet egykorú, így minden valószínüség szerint egyazon népesség lakó- és temetkezési helyét sikerült dokumentálni. A közvetlen kapcsolatot bizonyítja az alsóhúros vasfibula típusa, amely mind a telepen, mind a temető egyik sírjában napvilágot látott, valamint a sír- és településkerámia hasonló jellege. Ezen kívül a lelőhely részben egykorú lehetett a közelben fekvő Nyíregyháza, keleti elkerülő 14. számú lelöhellyel is. ${ }^{182}$ Ez esetben is van közvetlen kapcsolat a temetkezőhely és a településobjektumok között, s ennek bizonyítékaként az 58. lelőhely 6. sírja és a 14 . lelőhely 39. objektuma kék üvegpohár-töredékeit és Murga-típusú korsóját említhetjük. Elképzelhetőnek tartjuk, hogy az egymáshoz közel fekvő, tanyaszerű települési egységek lakói ugyanazt a temetkezőhelyet használták. Ugyanakkor e települések kronológiai helyzete némileg eltérő volt, a kerámiaanyag jellege alapján Pintye Gábor a 14. lelőhelyet inkább az 5. század első felére keltezte (bár a 6. - öntött kengyelfibulás - sírral való közvetlen kapcsolat valamivel későbbi használatot is megenged), míg az 58. számú, ahogy fentebb említettük, a század második felében lehetett használatban. ${ }^{183}$

A lelőhelyen feltárt állatcsontanyag összetétele megfelel a korszak más lelőhelyein tapasztalt képnek. A fajonkénti eloszlás szarvasmarha dominanciát mutat, ezt követik a kiskérődzők, a sertés és végül a ló. A szarvasmarhacsontok különböző méretű és testalakú egyedek előfordulására, és az állatok változatos célú (hús, tej, bőr) felhasználására engednek következtetni. ${ }^{184}$

A Nyíregyháza határában feltárt lelőhely egy olyan „temetötípust" képvisel, amely korábban nem volt ismert a Kárpát-medence északkeleti részéből, ugyanis későbbi, mint a késő szarmata-hun kori, vagy az ún. Tiszadob-típusú, a 4-5. század fordulóján létesített temetkezőhelyek, de korábbi, mint

\footnotetext{
${ }^{180}$ Pl. Tiszalök, Mád (Kovrig 1951) vagy Mezőkövesd-Mocsolyás (Lovász 1999).

${ }^{181}$ Csallány 1958, 85.

${ }^{182}$ Pintye 2016.

${ }^{183}$ Pintye 2016, 111.

${ }^{184}$ Ld. Bárány Annamária feldolgozását e tanulmány appendixeként.
}

az 5. század 2. felében induló nagyméretű, soros temetők. Leginkább azokkal a kisebb sírszámú temetőkkel rokonítható, mint például a Bácskából a bodrogmonostorszegi vagy a Dunántúlról a balatonszemesi lelőhely. ${ }^{185}$ A környékről Kótaj (10 sír), ${ }^{186}$ Nyíregyháza-Oros (8 sír) ${ }^{187}$ és NyíregyházaRozsrétszőlő (34 sír) ${ }^{188}$ említhető, mint hasonló korú temetkezőhely.

A lelőhely szűkebb környezete a hun korra és a kora népvándorláskorra vonatkozóan jól kutatott (16. kép). A korábbi időszak szarmata népessége nagyobbrészt megélhette a hun uralom időszakát, ráadásul a régészeti adatokból úgy tűnik, hogy ezen a területen éppen ebben az időben nőtt meg a lakosság lélekszáma, feltehetően az ide irányuló migráció miatt. ${ }^{189}$ Nyíregyháza környékén nagyberuházásokhoz kapcsolódó megelőző feltárásoknak köszönhetően több nagyméretü, késő szarmata település és temető is feltárásra került, használatuk felső időhatáráról azonban csak feldolgozásuk és közzétételük után lesz pontos információnk. ${ }^{190}$ E szarmata lelőhelyek közelében hun kori magányos sírok is előkerültek, amelyek a hun birodalmi szervezethez tartozó, a helyi lakosság fölé rendelt vezetőknek és családjaiknak, valamint a környéken rövid ideig megtelepedő új csoportoknak lehetnek a bizonyítékai. ${ }^{191}$

Az M3-58. lelőhely 5. század derekán alapított települése a késő szarmata telepekhez képest új típusú anyagi kultúrát tükröz. A régióban szintén nem áll egyedül: a publikált Csorda-Páskum I. (M3-14. lh.) területén feltárt tanyán ${ }^{192}$ kívül hasonló lelőhelyekkel számolhatunk az M3-182. lelöhely és Nyíregyháza-Ipari Park IV. területén is. A legkésőbbi szarmata telepek teljes anyagspektrumának megismerése után lehet csak eldönteni a kérdést, hogy az anyagi kultúrában tapasztalt eltérés kronológiai vagy egyéb, etnikus okokra vezethetö-e vissza, illetve, hogy számolhatunk-e a két „csoport” párhuzamos jelenlétével. Árnyalja a képet, hogy az 58. lelőhelyen megfigyelt jelenségek egy része - sarokoszlopos épület, szemcsés, korongolt, S-profilú tálak, Murga-típusú korsók - olyan 5. századi lelőhelyeken is feltűnik a Kárpátmedence északi részén, melyek kerámia leletanyaga nem

${ }^{185}$ GubitZa 1899; GubitZa 1902; MinácZi-PÁlfi 2018.

${ }^{186}$ Kótaj-Verba tanya. Ld. 37. jegyzet. E lelőhelyek kronológiai helyzetét publikálásuk után tudjuk majd összevetni az általunk elemzett temetővel.

${ }^{187}$ Nyíregyháza-Oros, Úr-Csere (M3 keleti elkerülő 26. lelőhely): MARTA et al. 2005a.

${ }^{188}$ Nyíregyháza-Rozsrétszőlő, Nevelős-homokbányától D-re (Vargatábla): AlmÁssy et al. 2006a.

${ }^{189}$ IsTVÁNOVITS- KuLCSÁR 2018, 254.

${ }^{190}$ Fontos adat, hogy a nagykállói Kis-Ludastó-dűlőben feltárt hun kori magányos sírra ráástak egy gödröt, ami egyértelmüen a késő szarmata településhez tartozott. Ez alapján a település használata bőven benyúlt a hun korba (PINTYe 2018a, 292, 294). Ugyancsak a hun korszakra utal Nyíregyháza-Oros 33. lelőhelyének áldozati leletegyüttese (IsTVÁNOviTs-KuLCSÁR 2014).

${ }^{191}$ Vö. 42. jegyzet. E sírok leletanyaga nem feltétlenül utal elitre, lásd Pintye 2018a.

${ }^{192}$ Pintye 2016. 
vezethető le a korábbi helyi hagyományból, így diszkontinuus a késő római kori horizonttal. ${ }^{193}$

A település és a temető használóiról etnikai szempontból annyit állapíthatunk meg, hogy a hun kor változatos összetételü népességének egy csoportja élt itt a Hun Birodalom utolsó éveinek és a Gepida Királyság kialakulásának átmeneti időszakában. A lelőhely azokat a temetkezési szokásokat, öltözetet és használati tárgyakat reprezentálja, amelyek az 5. század középső harmadában és második felében széles körben jellemzőek voltak a Kárpát-medencében. A terület a század második felében a Gepida Királyság érdekszférájába tartozhatott. Innen kb. $25 \mathrm{~km}$-re nyugatra található Hajdúnánás-Fürj-halom-dűlő lelőhelye, amely nagyobb sírszáma, hosszú használati ideje és az itt lelt tárgytípusok alapján már a gepida kori soros temetők jellegzetes képének felel meg. ${ }^{194}$

\section{IRODALOM}

\section{AlFÖLDI, ANDRÁs}

1932 Leletek a hun korszakból és ethnikai szétválasztásuk (Funde aus der Hunnenzeit und ihre ethnische Sonderung). Archaeologia Hungarica 9. Budapest.

Almássy Katalin-Astaloş, Ciprian-Babolcsi Andrea-Gergely Balázs-Istvánovits EszTer-Virag, Cristian

2006a Nyíregyháza-Rozsrétszőlő, Nevelős-homokbányától D-re (Vargatábla). In: Kisfaludi, J. (szerk.): Régészeti Kutatások Magyarországon 2005 (Archaeological Investigations in Hungary 2005). Budapest, 291-292.

Almássy Katalin-Bejinariu, Ioan-Gindele Róbert-Pop, HoreaLiviu, Marta-Matei, AleXandru-Nagy Márta-Pintye Gábor

2006b Nyíregyháza-Császárszállás, Vasútállomástól Nyugatra (Butyka). In: Kisfaludi, J. (szerk.): Régészeti Kutatások Magyarországon 2005 (Archaeological Investigations in Hungary 2005). Budapest, 288.

Aspöck, Edeltraud

2003 Graböffnungen im Frühmittelalter und das Fallbeispiel der langobardenzeitlichen Gräber von Brunn am Gebirge, Flur Wolfholz, Niederösterreich. Archaeologia Austriaca 87, 225264. DOI: https://doi.org/10.1553/archaeologia87s225

BÁcsmegi, GÁbor-GUBA, SzILvia

2007 Letünt korok emlékezete. Szurdokpüspöki régmúltja a legújabb régészeti kutatások tükrében. Szurdokpüspöki.

BÁlint, CsABA-Soós, EszTER-TöröK, BÉLA

2019 Előzetes jelentés Andornaktálya-Kis-Rét-dűlő hun kori lelőhelyről (Preliminary report on the Andornaktálya-Kis-Rétdűlő Hun Age site). Agria - Az Egri Múzeum évkönyve 52, 169-190.

BÁRKÁNYI, MAGDOLNA

2010 Gyöngyök a Kiszombor B gepida temetőben. Szakdolgozat. Szegedi Tudományegyetem, Szeged.

${ }^{193}$ Szarmata területen a legújabb, részletesen feldolgozott település Rákóczifalva-Bagi-földek 5-8-8A lelöhely 2. településhorizontja (MAseK 2018, 342), de önálló település pl. AndornaktályaKis-rét-dülő (BÁLINT et al. 2019); a Kárpát-medencei Przeworskkultúra területén Hernádvécse (Soós et al. 2017), vagy OngaTeknő lapos (Soós 2014).

${ }^{194}$ RÁCZ 2019.
BARKóCZI, LÁsZLó

1988 Pannonische Glasfunde in Ungarn. Studia Archaeologica 9. Budapest.

T. BÍRó, MÁRIA

2002 Combs and comb-making in Roman Pannonia: ethnical and historical aspects. In: Tejral, J. (Hrsg.): Probleme der frühen Merowingerzeit im Mitteldonauraum. Spisy Archeologického ústavu AV ČR Brno 19. Brno, 99-124.

Bocsi, Zsófia

2016 A nádudvari gepidák nyomában. Egy többrétegű szarmata és gepida település feldolgozásának első lépései (In search of the Gepids of Nádudvar - Preliminary assessment of a stratified Sarmatian and Gepidic settlement). In: Kovács L.-Révész L. (föszerk.): Népek és kultúrák a Kárpát-medencében. Tanulmányok Mesterházy Károly tiszteletére. Budapest-DebrecenSzeged, 23-79.

BóNA, IsTVÁN

2002a Barabás-Bagolyvár. In: BóNA-NAGY 2002a, 17-22.

2002b Domoszló-Víztároló. In: BónA-NAGY 2002a, 27-28.

BónA, István-NAGY, Margit

2002a Gepidische Gräberfelder am Theissgebiet I. Monumenta Germanorum Archaeologica Hungariae 1. Budapest.

2002b Hódmezővásárhely-Kishomok. In: BóNA-NAGY 2002a, 34189.

BóNA, IsTVÁN-SzABó, János Győző

2002 Tarnaméra-Urak dűlője. In: BóNA-NAGY 2002a, 240-243.

BózsA, ANikó

2016 A szépségápolás tárgyi emlékanyaga Pannonia Magyarországra eső részén. Doktori disszertáció. Eötvös Loránd Tudományegyetem, Budapest.

BRATHER, SEBASTIAN

2005a Kleidung und Identität im Grab. Gruppierungen innerhalb der Bevölkerung Pleidelsheim zur Merowingerzeit. Zeitschrift für Archäologie des Mittelalters, 1-58.

2005b Alter und Geschlecht zur Merowingerzeit. Soziale Strukturen und frühmittelalterliche Reihengräberfelder. In: Müller, J. (Hrsg.): Alter und Geschlecht in ur- und frühgeschichtlichen Gesellschaften. Universitätsforschungen zur prähistorischen Archäologie 126. Bonn, 157-178. DOI: https://doi.org/ 10.11588/ai.2006.1\&2.11113

BROWN, DAVID

1974 So-called „Needle Cases”. Medieval Archaeology 18, 151-154. BudinsKÝ-KRIČKA, VOJTECH

1957 Gräber aus der römischen und der Völkerwanderungszeit in Kapušany (bez.Prešov). Slovenská archeológia 5:2, 356-362.

CSAllány, DeZső

1958 Hamvasztásos és csontvázas hun temetkezések a Felső-Tisza vidékén (Die hunnenzeitlichen Brand- und Skelettgräber in den Gebieten am oberen Lauf der Theiss). A Herman Ottó Múzeum Évkönyve 2, 83-99.

1961 Archäologische Denkmäler der Gepiden im Mitteldonaubecken (454-589 u. Z.). Archaeologia Hungarica 38. Budapest

CsEH, JÁNos

1999 Üvegleletek a 4-6. századból a Kengyel környéki településeken. Kutatástörténeti áttekintés (Glass finds from the $4^{\text {th }}-6^{\text {th }}$ centuries on settlements in environs of Kengyel. With a short history of research). Tisicum - A Jász-Nagykun-Szolnok megyei múzeumok évkönyvei 11, 25-29.

2005a Szolnok-Zagyva-part, Alcsi. In: CsEH et al. 2005, 18-33.

2005b Tiszaföldvár-Érhalom, Patkós tanya. In: CseH et al. 2005, 34-36.

Cseh, János-Istvánovits, Eszter-LovÁsz, Emese-Mesterházy, KÁroly-Nagy, Margit-M. Nepper, Ibolya-Simonyi, Erika

2005 Gepidische Gräberfelder im Theissgebiet II. Monumenta Germanorum Archeologica Hungariae 2. Budapest. 
Cs. Dax, Margit

1980 Keleti germán női sírok Kapolcson (Ostgermanische Frauengräber in Kapolcs). A Veszprém Megyei Múzeumok Közleményei 15, 97-106.

DÉvai, Kata

2012 Késő római temetkezések üvegmellékletei Pannoniában. Doktori disszertáció. Eötvös Loránd Tudományegyetem, Budapest. http://www.doktori.hu/index.php?menuid=193\&vid=11176

Dobos, Alpár

2014a Plunder or ritual? The phenomenon of grave reopening in the row-grave cemeteries from Transylvania $\left(6^{\text {th }}-7^{\text {th }}\right.$ centuries). In: Gligor, M. (ed.): Archaeothanatology: an interdisciplinary Approach on Death from Prehistory to the Middle Ages. Annales Universitatis Apulensis, Series Historica 18:2. Alba Iulia, 135-162.

2017 A népesség változásai a Kárpát-medence keleti felében (5. század közepe - 7. század). Soros temetők Erdélyben, Partiumban és a Bánság romániai részén. Doktori disszertáció. Eötvös Loránd Tudományegyetem, Budapest. DOI: http://doi. org/10.15476/ELTE.2017.035

Dobos, Alpár-GÁl, SZilárd SÁNDOR-Kelemen, IMOLA-NeparácZKi, ENDRE

$20215^{\text {th }}$-century burials from Sângeorgiu de Mureș-Kerekdomb (Mureș County, Romania). In: Rácz, Zs.-Szenthe, G. (eds): Attila's Europe. Structural transformation and strategies of succes in the European Hun period. Budapest, 327-360.

DövénYi, ZOLTÁN

2010 Magyarország kistájainak katasztere. Budapest.

EgGERS, HANS JÜrgeN

1951 Der römische Import im freien Germanien. Text. Tafeln und Karten. Hamburg.

Fenyvesi, Bianka

2020 Szarmata kori üvegedényes sírok az Alföldön. Diplomamunka, Eötvös Loránd Tudományegyetem, Budapest.

Garam, Éva-H. Vaday, ANDrea

1990 Sarmatische Siedlung und Begräbnisstätte in Tiszavalk. Communicationes Archaeologicae Hungariae, 171-219.

Gindele, Robert-Istvánovits, EszTer

2009 Die römerzeitliche Siedlung von Csengersima-Petea. Satu Mare.

Gindele, Róbert-Matei， Alexandru-Virag，Cristian-BăcueţCrişan, Daniel-Băcueţ-Crişan, Sanda-Marta, Liviu-Pop, HoreaSzékely, Zsolt-Bejinariu, Ioan- Sana, Daniel

2005 Nyíregyháza-Oros, Úr-Csere Észak. In: Kisfaludi, J. (szerk.): Régészeti Kutatások Magyarországon 2004 (Archaeological Investigations in Hungary 2004). Budapest, 257.

Gubitza, KÁlmán

1899 A bodrogh-monostorszegi leletekről. Archaeologiai Értesítő 19, 264-268.

1902 A bodrogh-monostorszegi sírleletekről. Archaeologiai Értesítő $22,338-342$.

Gulyás, Bence-Rácz, Zsófia-Bajnok Katalin-Gait, John

2019 A solitary $5^{\text {th }}$ century burial from Szilvásvárad-Lovaspálya, North-east Hungary. In: Vida, T.-Quast, D.-Rácz, Zs.-Koncz, I. (Hrsg.): Kollaps - Neuordnung - Kontinuität. Tagungsakten der Internationalen Konferenz an der Eötvös Loránd Universität, Budapest, 14.-15. Dezember 2015. Budapest, 431-458.

HaLsall, GuY

2010 Cemeteries and Society in Merovingian Gaul. Selected Studies in History and Archaeology, 1992-2009. Brill's Series on the Early Middle Ages 18 . Leiden-Boston.

ILON, GÁBOR

1999 Hun kori temető részlete Nagydém-Középrépáspusztán (Hunnenzeitlicher Gräberfeldteil in Nagydém-Középrépáspuszta).
In: S. Perémi, Á. (szerk.): A népvándorláskor fiatal kutatói 8. találkozójának előadásai (Veszprém, 1997. november 28-30). Veszprém, 28-46.

IsTVÁNovits, EsZTER

1993 Das Gräberfeld aus dem 4.-5. Jahrhundert von TiszadobSziget. Acta Archaeologica Academiae Scientiarum Hungaricae $45,91-146$.

1999 Tiszavasvári-Város földje-Jegyzö tag. A settlement of the $5^{\text {th }}$ century. A nyíregyházi Jósa András Múzeum Évkönyve 41, 173-254.

2012 Nyíregyháza-Oros, Kánya-hegy-dülő. In: Kisfaludi, J. (szerk.): Régészeti Kutatások Magyarországon 2010 (Archaeological Investigations in Hungary 2010). Budapest, 308-309.

IsTVÁNOVITS, ESZTER-KulCSÁR, VALÉRIA

1999 Sarmatian and Germanic people at the Upper Tisza Region and South Alföld at the Beginning of the Migration Period. In: Tejral, J.-Pilet, Ch.-Kazanski, M. (eds): L'Occident romain et l'Europe centrale au début de lépoque des Grandes Migrations. Spisy Archeologického ústavu AV ČR Brno 13. Brno, 67-94.

2014 New Find of Hun Age Saddle Plates from North-East Hungary. In: Cociş, S. (Hrsg.): Archäologische Beiträge - Gedenkschrift zum hundertsten Geburtstag von Kurt Horedt. Cluj-Napoca, 269-278.

2018 A hun kori barbárok társadalmi rétegződése a legújabb magyarországi kutatások fényében (Die gesellschaftliche Schichtung der hunnenzeitlichen Barbaren im Lichte der neuesten ungarischen Forschungen). In: Korom, A.-Balogh, Cs.-Major, B.Türk, A. (szerk.): Relationes rerum. Régészeti tanulmányok Nagy Margit tiszteletére (Archäologische Studien zu Ehren von Margit Nagy). Studia ad Archaeologiam Pazmaniensia 10. Budapest, 253-267.

IVANišević, VUjadin-KaZanski, Michel-Mastykova, ANNA

2006 Les nécropoles de Viminacium à lépoque des Grandes Migrations. Collège de France - CNRS Centre de Recherche d'Histoire et Civilisation de Byzance. Monographies 22. Paris. KISS, Alpár

2015 A zsámboki 5. századi temető. Alapszakos szakdolgozat. Eötvös Loránd Tudományegyetem, Budapest.

2017 Magányos temetkezések és kis sírcsoportok a Kárpát-medencében az 5. században. Diplomamunka. Eötvös Loránd Tudományegyetem, Budapest.

Kiss, AtTila

1981 Germanischer Grabfund der Völkerwanderungszeit in Jobbágyi (Zur Siedlungsgeschichte des Karpatenbeckens in den Jahren 454-568). Alba Regia 19, 167-185.

1996 Das Gräberfeld von Szekszárd-Palánk aus der zweiten Hälfte des 5. Jh. und der ostgotische Fundstoff in Pannonien. Zalai Múzeum 6, 53-86.

1999 Glassfunde aus Gräbern des frühmittelalterlichen Karpatenbeckens (400-1000). Antaeus 24, 217-241.

Kiss P., AtTILA

2014 „... ut strenui viri...”. A gepidák Kárpát-medencei története (The history of the Gepids in the Carpathian Basin). Szeged.

KLein, Michael J.

1999 Römische Gläser: Formen, Farben und Dekore. Zur Ausstellung „Römische Glaskunst und Wandmalerei”. In: Klein, M. J. (Hrsg.): Römische Glaskunst und Wandmalerei. Ausstellung des Landesmuseums Mainz vom 12. Dezember 1999 bis 20. Februar 2000. Mainz, 1-20.

Kolník, Titus-VARsik, Vladimir-VladÁr, JAN

2007 Branč. Germánska osada z 2. až 4. storočia. Eine germanische Siedlung vom 2. bis zum 4. Jahrhundert. Archaeologica Slovaca Monographiae Catalogi 10. Nitra. 
Ny. Kovacsóczy, BernadetT-Rácz, Zsófia-Mozgai, VikTóriaMarcsik, Antónia-Bajnóczi, Bernadett

2021 Archaeological and natural scientific studies on the Hunperiod grave from Kecskemét-Mindszenti-dülö. In: Rácz, Zs.Szenthe, G. (eds): Attila’s Europe. Structural transformation and strategies of succes in the European Hun period. Budapest, 305-326.

KOVRIG, ILONA

1951 A tiszalöki és a mádi lelet. Archaeologiai Értesítő 78, 113-120. KöRÖSFŐI, ZsOLT

2008 A Marosszentanna-Černjachov-kultúra három temetkezése a Rugonfalva-Református papilak lelőhelyen (Die Gräber des Černjachov-Sântana de Mureş-Kultur aus Rugonfalva). Acta Siculica, 189-207.

KüHN, HerberT

1974 Die germanischen Bügelfibeln der Völkerwanderungszeit in Süddeutschland. Graz.

Lovász, Emese

1999 Hun és germán jellegü leletek Borsod megyében (Hunnische und germanische Funde im Komitat Borsod). A Herman Ottó Múzeum Évkönyve 37, 237-265.

2005 Mezőkövesd-Mocsolyás. In: CsEH et al. 2005, 50-53.

Markó, ANDRÁs

2011 Nyíregyháza, Harangod. In: Kisfaludi, J. (szerk.): Régészeti Kutatások Magyarországon 2010 (Archaeological Investigations in Hungary 2010). Budapest, 308.

Marta, Liviu-Astalos, Ciprian-Kádas Zoltán-Virag, CristianSANA, DANIEL:

2005a Nyíregyháza-Oros, Úr-Csere. In: Régészeti Kutatások Magyarországon (Archaeological Investigations in Hungary) 2004. Budapest, 256-257.

Marta, Liviu-Kádas Zoltán-Astalos, Ciprian

2005b Nyíregyháza-Oros, Lévai-tag. In: Kisfaludi, J. (szerk.): Régészeti Kutatások Magyarországon 2004 (Archaeological Investigations in Hungary 2004). Budapest, 255

MASEK, ZsófIA

2013 Die kulturellen Beziehungen der hunnenzeitlichen Eliten im östlichen Mitteldonaugebiet am Beispiel der einglättverzierten Drehscheibenkeramik. In: Hardt, M.-Heinrich-Tamáska, O. (Hrsg.): Macht des Goldes, Gold der Macht. Herrschaft- und Jenseitsrepräsentation zwischen Antike und Frühmittelalter im mittleren Donauraum. Akten des 23. Internationalen Symposiums der Grundprobleme der frühgeschichtlichen Entwicklung im mittleren Donauraum, Tengelic, 16-19. 11. 2011. Weinstadt, 229-251.

2015 Száz gepida ház - A rákóczifalvi gepida település szerkezete ("Hundred Gepid dwellings" - The structure of the Gepid settlement at Rákóczifalva). In: Türk, A. (szerk.): Hadak Útján XXIV. A népvándorláskor fiatal kutatóinak XXIV. konferenciája, Esztergom, 2014. november 4-6. (Conference of Young Scholars on the Migration Period. November 4-6, 2014, Esztergom). Budapest-Esztergom, 407-446.

2016 The transformation of Late Antique comb types on the frontier of the Roman and Germanic world. Early medieval antler combs from Rákóczifalva (County Jász-Nagykun-Szolnok, Hungary). Antaeus 34, 105-172.

2018 A Közép-Tisza-vidék településtörténete a Kr. u. 4-6. században Rákóczifalva-Bagi-földek 5-8-8A. lelőhely értékelése alapján. Doktori Disszertáció. Eötvös Loránd Tudományegyetem, Budapest.

Mesterházy, Károly

2005 Ártánd-Lencsésdomb. In: CseH et al. 2005, 54-57.

MÉszÁros, Gyula

1970 A regölyi korai népvándorláskori fejedelmi sír (Das Fürstengrab von Regöly aus der Frühvölkerwanderungszeit). Archaeologiai Értesítő 97, 66-93.
MiháCZI-PÁlfi, ANetT

2018 A balatonszemesi 5. századi temető kisleletei. In: Rácz, Zs.Koncz, I.-Gulyás, B. (szerk.): "Hadak útján." A népvándorláskor fiatal kutatóinak XXVI. konferenciája. Gazdaság - kereskedelem - kézmüvesség ( $26^{\text {th }}$ Conference of Young Scholars on the Migration Period. Economy - Trade - Chraftsmanship). Dissertationes Archaeologicae Supplementum 2, 129-161. DOI: https://doi.org/10.17204/dissarch.suppl2.129

NAGy Margit

1993 Gepida temetkezés és vallási élet. In: Bóna, I.-Cseh, J.-Nagy, M.Tomka, P.-Tóth, Á.: Hunok - Gepidák - Langobardok. Magyar Östörténeti Könyvtár. Szeged, 60-61.

2004 A hódmezővásárhely-kishomoki gepida temető (Das gepidische Gräberfeld von Hódmezővásárhely-Kishomok). A Móra Ferenc Múzeum Évkönyve - Studia Archaeologica 10, 129239.

2005a Kora népvándorlás kori gyermeksír amulettekkel Mártélyról (Csongrád megye) ( $5^{\text {th }}$ century child grave with amulets and iron bell from Mártély, (Csongrád County). Zalai Múzeum 14, 97-127.

2005b Szőreg-Téglagyár. In: CseH et al. 2005, 120-202.

NÄSMAN, UlF

1984 Glas och handel i senromersk tid och folkvandringstid. Uppsala.

NÉmeth, PÉTer

1988 Frühgepidische Grabfunde an der oberen Theiss. In: Menghin, W.-Springer, T.-Wamers, E. (Hrsg.): Germanen, Hunnen und Awaren. Schätze der Völkerwanderungszeit. Ausstellungskatalog des Germanischen Nationalmuseums. Nürnberg, 219-222.

NÉMETI, JáNOS

1967 Descoperiri funerare din sec. V e.n. língá Carei (Grabfunde der 5. Jhs. u.Z. aus der Umgebung der Stadt Carei). Acta Musei Napocensis 4, 499-507.

ÓDOR, JÁNOS GÁBOR

2011 The $5^{\text {th }}$-century cemetery and settlement at Mözs (Tolna County, Hungary) - Some issues concerning the „East Germanic” period in Transdanubia. In: Heinrich-Tamáska, O. (Hrsg.): KeszthelyFenékpuszta im Kontext spätantiker Kontinuitätsforschung zwischen Noricum und Moesia. Castellum Pannonicum Pelsonense 2. Budapest-Leipzig-Keszthely-Rahden/Westf., 347-360.

OtTOMÁNYi, KATALIN

2001 „Hunkori” sírok a pátyi temetőben („Hunnenzeitliche” Gräber im Gräberfeld von Páty). Archaeologiai Értesítő 126, 35-74. DOI: https://doi.org/10.1556/archert.126.2001.1-2.2

PÁRduCZ, MiHÁLY

1950 A szarmatakor emlékei Magyarországon III. (Denkmäler der Sarmatenzeit Ungarns III). Archaeologia Hungarica 30. Budapest.

1959 Archäologische Beiträge zur Geschichte der Hunnenzeit in Ungarn. Acta Archaeologica Academiae Scientiarum Hungaricae $11,309-398$.

1963 Die ethnischen Probleme der Hunnenzeit in Ungarn. Studia Archaeologica I. Budapest.

Pieta, Karol-Ruttkay, Matej

1997 Germanische Siedlung aus dem 5. und 4. Jh. in Nitra-Párovské Háje und Probleme der Siedlungskontinuität. In: Tejral, J.Friesinger, H.-Kazanski, M. (Hrsg.): Neue Beiträge zur Erforschung der Spätantike im Mittleren Donauraum. Spisy Archeologického ústavu AV ČR Brno 8. Brno, 145-163.

Pintye Gábor

2009 A Kárpát-medencei szarmata települések csontfésüi (Die Beinkämme der Sarmatensiedlungen im Karpatenbecken). Archaeologiai Értesítő 134, 165-195. DOI: https://doi. org/10.1556/archert.134.2009.10 
2014 Magányos hunkori temetkezések Nyíregyháza határában (Hun Age single graves at the track of Motorway M3). A nyíregyházi Jósa András Múzeum Évkönyve 56, 109-140.

2016 Hun kori - kora népvándorlás kori telepnyomok Nyíregyháza és Nagykálló között (Nyíregyháza-Csorda-Páskum I-II.) (Settlement traces from the Hun Age and Early Migration Period between Nyíregyháza and Nagykálló). A nyíregyházi Jósa András Múzeum Évkönyve 58, 67-153.

2018a Szándékos vagy véletlen? Újabb „magányos” kora népvándorlás kori sírok Nagykálló határában (Absichtlich, oder zufällig? Neu entdeckte frühvölkerwanderungszeitliche Einzelgräber an der Grenze von Nagykálló, Kom. Szabolcs-Szatmár-Bereg, Ungarn). In: Korom, A.-Balogh, Cs.-Major, B.-Türk, A. (szerk.): Relationes rerum. Régészeti tanulmányok Nagy Margit tiszteletére (Archäologische Studien zu Ehren von Margit Nagy). Studia ad Archaeologiam Pazmaniensia 10. Budapest, 291-305.

2018b Kora népvándorlás kori falu és agancsműves műhely Nyíregyháza-Rozsrétszőloőől (M3 182. lh. és Ipari Park Marso telephelye) (Early Migration Period village and antler workshop from Nyíregyháza-Rozsrétszőlő [Motorway M3 Site 182 and Marso site of the Industrial Park]). In. L. Nagy, M.L. Szőlősi K. (eds): „Vadrózsából tündérsípot csináltam.” Tanulmányok Istvánovits Eszter 60. születésnapjára ("To make a fairy's whistle from a briar rose." Studies presented to Eszter Istvánovits on her sixtieth birthday). Nyíregyháza, 445-476.

RAC

Reallexikon für Antike und Christentum. Stuttgart.

RÁCZ, ZsóFiA

2014 5. századi sírok Hajdúnánás-Fürj-halom-dűlő (M3-41/A) lelőhelyről (Gräber aus dem 5. Jahrhundert von NordostUngarn. Fundort Hajdúnánás-Fürj-halom-járás). In: Anders A.Balogh Cs.-Türk A. (szerk.): Avarok pusztái. Tanulmányok Lőrinczy Gábor 60. születésnapjára (Avarum solitudines. Archaeological studies presented to Gábor Lörinczy on his sixtieth birthday). Opitz Archaeologica 6 - MTA BTK MÖT Kiadványok 2. Budapest, 203-213.

2016 Zwischen Hunnen- und Gepidenzeit. Frauengräber aus dem 5. Jahrhundert im Karpatenbecken. Acta Archaeologica Academiae Scientiarum Hungaricae 67, 301-360. DOI: https:// doi.org/10.1556/072.2016.67.2.6

2019 A gepida királyság peremén. 5-6. századi temetők Hajdúnánás határából. Habilitációs dolgozat. Eötvös Loránd Tudományegyetem, Budapest.

RÁcZ, Zsófia-DarócZi-Szabó, Márta

2016 Szarvasszemfog-csüngők kora népvándorlás kori sírokban (Deer canine pendants from early Migration period burials). In: Kovács L.-Révész L. (főszerk.): Népek és kultúrák a Kárpátmedencében. Tanulmányok Mesterházy Károly tiszteletére. Budapest-Debrecen-Szeged, 179-185.

SCHOLTZ, RóBERT

2019 163. Nagykálló, Kis-Ludastói-dűlő. In: Kvassay, J. (szerk.): Régészeti Kutatások Magyarországon 2012 (Archaeological Investigations in Hungary 2012). Budapest, 75.

SimONYI, ERIKA

1999 Gepida temető Mezőkeresztes-Cethalmon (Gepidic Cemetery at Mezőkeresztes-Cethalom). In: S. Perémi Á. (szerk.): A népvándorláskor fiatal kutatói 8 . találkozójának előadásai (Veszprém, 1997. november 28-30). Veszprém, 72-86.

SOMOgYi, PÉTER

2019 Spätrömisch-byzantinische Fundmünzen aus Gepidengräbern In: Vida, T.-Quast, D.-Rácz, Zs.-Koncz, I. (Hrsg.): Kollaps Neuordnung - Kontinuität. Gepiden nach dem Untergang des Hunnenreiches. Tagungsakten der Internationalen Konferenz an der Eötvös Loránd Universität, Budapest, 14.-15. Dezember 2015. Budapest, 603-625.

Soós, EszTer

2014 Kr. u. 5. századi teleprészlet a Hernád mentén (Parts of a $5^{\text {th }}$ c. A.D. settlement by the Hernád river, Hungary). A Herman Ottó Múzeum Évkönyve 53, 183-211.

2016 Settlement history of the Hernád Valley in the 1 st to $4 / 5^{\text {th }}$ centuries AD. Dissertationes Archaeologicae 3/4, 449-466. DOI: https://doi.org/10.17204/dissarch.2016.449

2019a A császárkori germán Przeworsk kultúra kutatásának legújabb eredményei Magyarországon. Archeologiai Értesítő 144, 6795. DOI: https://doi.org/10.1556/0208.2019.144.3

2019b Transformation der Siedlungen am Ende des 4. und im 5. Jahrhundert in Nordost-Ungarn. In: Vida, T.-Quast, D.Rácz, Zs.-Koncz, I. (Hrsg.): Kollaps - Neuordnung - Kontinuität. Gepiden nach dem Untergang des Hunnenreiches. Tagungsakten der Internationalen Konferenz an der Eötvös Loránd Universität, Budapest, 14.-15. Dezember 2015. Budapest, 697-752.

Soós, Eszter-Bárány, Annamária-Köhler, Kitti-Pusztai, Tamás 2017 Settlement and graves from Hernádvécse (NE-Hungary) in the $5^{\text {th }}$ century AD: relation of living space and burial place in the Hun Period (Kr. u. 5. századi telep és temetkezések Hernádvécséről: adatok a lakóhely és a temetkezések kapcsolatához a hun korban). A Herman Ottó Múzeum Évkönyve 56, 49-98. SOROKINA, NINA

1970 Die Nuppengläser von der Nordküste des Schwarzen Meeres. Annales Association Internationale pour l'Histoire du Verre 5, 71-79.

Szabó, JÁNos József

1978 Népvándorlás kori teleprészlet és Árpád-kori településnyomok Battonya határában (Völkerwanderungszeitlicher Siedlungsteil und arpadenzeitliche Siedlungsspuren in der Nähe von Battonya). A Békés Megyei Múzeumok Közleményei 5, 61-85.

1990 Késő római kori - kora népvándorlás kori sír- és teleprészlet Füzesabony határában (Grab und Siedlungsteil aus der späten Römerzeit - frühen Völkerwanderungszeit in der Gemarkung von Füzesabony, Nordungarn). Agria - Az egri Dobó István Vármúzeum Évkönyve 25-26, 175-193.

SZABó, JÁNos JózsEF-VöRös, IstváN

1979 Gepida lelőhelyek Battonya határában (Gepidische Fundorte in der Gemarkung von Battonya). Archaeologiai Értesítő 106, 218-230.

Tejral, Jaroslav

1990 Archäologischer Beitrag zur Erkenntnis der völkerwanderungszeitlichen Ethnostrukturen nördlich der mittleren Donau. In: Friesinger, H.-Daim, F. (Hrsg.): Typen der Ethnogenese unter besonderer Berücksichtigung der Bayern, Teil 2. Wien, 9-87.

1997 Neue Aspekte der frühvölkerwanderungszeitlichen Chronologie im Mitteldonauraum. In: Tejral, J.-Friesinger, H.Kazanski, M. (Hrsg.): Neue Beiträge zur Erforschung der Spätantike im mittleren Donauraum. Spisy Archeologického ústavu AV ČR Brno 8. Brno, 321-392.

1998 Die Besonderheiten der germanischen Siedlungsentwicklung während der Kaiserzeit und der frühen Völkerwanderungszeit in Mähren und ihr Niederschlag im archäologischen Befund. In: Leube, A. (Hrsg.): Haus und Hof in östlischen Germanien. Bonn, 181-207.

2005 Smolin. In: Reallexikon der Germanischen Altertumskunde 29. Berlin-New York, 160-162.

2007 Das Hunnenreich und die Identitätsfragen der barbarischen "gentes" im Mitteldonauraum aus der Sicht der Archäologie. In: Tejral, J. (Hrsg.): Barbaren im Wandel. Beiträge zur Kultur- 
und Identitätsumbildung in der Völkerwanderungszeit. Spisy Archeologického ústavu AV ČR Brno 26. Brno, 55-120.

2011 Einheimische und Fremde. Das norddanubische Gebiet zur Zeit der Völkerwanderung. Spisy Archeologického ústavu AV ČR v Brně 33. Brno.

Tempelmann-Mączyńska, Magdalena

1985 Die Perlen der römischen Kaiserzeit und der frühen Phase der Völkerwanderungszeit im mitteleuropäischen Barbaricum. Römisch-Germanische Forschungen 43. Mainz.

TóBiÁs, BENDEgúz

2007 Néhány érdekes tárgy a Zillingtal-Unterer Kapellenberg D41. sírból. Csatfibulák és ecsetek (Einige interessante Gegenstände aus dem Grab D41 von Zillingtal-Unterer Kapellenberg. Ringfibeln und Pinsel). Archaeologiai Értesítő 132, 325-341. DOI: https://doi.org/10.1556/archert.132.2007.1.14

TOMKa, PÉTER

2001 Az árpási 5. századi sír (Grab in Árpás aus dem 5. Jahrhundert). Arrabona 39, 161-188.

B. Tóth ÁgNes

1994 Kora népvándorlás kori sírok Tápé-Szénteglaégetőn (Gräber aus der frühen Völkerwanderungszeit in Tápé-Széntéglaégető). In: Lőrinczy, G. (szerk.): A kőkortól a középkorig. Tanulmányok Trogmayer Ottó 60. születésnapjára (Von der Steinzeit bis zum Mittelalter. Studien zum 60. Geburtstag von Ottó Trogmayer). Szeged, 285-309.

2006 Gepidische Siedlungen im Theissgebiet. Monumenta Germanorum Archaeologica Hungariae 4. Budapest.
Tóth, ENdre-Vida, Tivadar-TaKács, ImRe (szerk.)

2016 Szent Márton és Pannónia. Kereszténység a római világ határán. Kiállítási katalógus. Pannonhalma-Szombathely.

VADAY, ANDREA-DOMBoRÓCZKI, LÁsZLó

2001 Mezőszemere-Kismari-fenék. Késő-császárkori - kora-népvándorláskori temetőrészlet (Mezőszemere-Kismari-fenék. Late Imperial - Early Migration Period cemetery fragment). Agria Az egri Dobó István Vármúzeum Évkönyve 37, 5-206.

VARGA, ZsóKA

2016 Népvándorláskori üvegedények a Kárpát-medencében. Alapszakos szakdolgozat. Eötvös Loránd Tudományegyetem, Budapest.

VARSIK, VLADIMIR

2011 Germánske osídlenie na vŷchodnom predpolí Bratislavy. Sídliská z doby rímskej v Bratislave-Trnávke a v okolí (Germanische Besiedlung am östlichen Vorfeld von Bratislava. Kaiserzeitliche Siedlungen von Bratislava-Trnávka und Umgebung). Archaeologica Slovaca Monographiae 18. Nitra.

VÖRÖS, GABRIELLA

1981 Adatok a szarmata kori női viselethez (Angaben zur sarmatenzeitlichen Frauentracht). Communicationes Archaeologicae Hungariae, 121-135

WERNER, JOACHIM

1959 Studien zu Grabfunden des V. Jahrhunderts aus der Slowakei und der Karpatenukraine. Slovenská archeológia 8:2, 422-438.

\title{
Settlement and cemetery from the $5^{\text {th }}$ century $\mathrm{AD}$ in the vicinity of Nyíregyháza (Site M3-58), Hungary
}

\author{
Attila Beck - Zsófia Rácz - Eszter Soós - Gábor Pintye
}

A cemetery and a part of a settlement have been excavated within the confines of the Nyíregyháza municipality between 2009 and 2011. Based on archaeological data, both were established by the same population in the middle of the $5^{\text {th }}$ century (Nyíregyháza-Csorda-Páskum, Site M3-58, Fig. 1) The cemetery had possibly been used jointly by the residents of several neighbouring homesteads, as the finds of a nearby settlement site also show close connections with the burial site (Nyíregyháza, keleti elkerülő út Site 14, Pintye 2016).

The scattered settlement phenomena, two buildings and several pits, were located 40-50 meters west of the graves (Fig. 2). Building no. 22/25 with six posts (Fig. 3, 6) represents the type Eckpfostenhaus, which appeared mainly in the northern zone of the Carpathian Basin, in connection with the changes during the Hun period. Structures similar to Building no. 18/20 with two posts (Fig. 3, 5) also had become widespread in the $5^{\text {th }}$ century and remained popular in Gepidic-period settlements. The small number of ceramic fragments did not contain remains of special vessels, but technological and formal characteristics (Murga-type jug, S-profile bowl, dominance of wheel-turned, grainy pots (Figs 5-6) display similarities with contemporaneous assemblages published from the region so far, such as HernádvécseNagy-rét, Onga-Teknő-lapos or Andornaktálya-Kis-rét-dülő. A large jug with two handles and smoothed-in decoration, and a grainy wheel-made vessel with a cylindrical rim (Fig. 4; Fig. 5, 3) can be associated with late Sarmatian pottery manufacture, while analogies of the mug (Fig. 5, 8) can be mentioned from Gepidic-period sites. The excavated part of the settlement is dated to the second half of the $5^{\text {th }}$ century.

The entire area of the burial ground belonging to the settlement has been excavated (Fig. 7). The 24 burials represent a cemetery type hitherto unknown in Northeast Hungary. It can be well distinguished from the late SarmatianHun-period burial grounds used in the late $4^{\text {th }}$ and early $5^{\text {th }}$ centuries, based on its rite (e.g., east-west orientation of the graves) and find material. The burial ground also differs from the so-called row-grave cemeteries (Reihengräberfeld) of the Gepidic period, established in the second half of the $5^{\text {th }}$ century AD in the Great Plain, because it can be dated somewhat earlier, and it was used for a much shorter period. 
Among the funerary rites, it is worth highlighting the case of a child's burial, Grave 6, in the head end of which a jug, a small pot and a blue glass cup were placed (Fig. 10; Fig. 22; Fig. 25). The placement of similar vessel sets in graves reflects Roman tradition and also appears regularly in Hun-period burials. Representative artefacts and costume elements from the Hun period and subsequent decades also came to light in the cemetery: for example, attires rich in beads, and hoops endowed with beads and metal pendants (Graves 6, 14, 16) (Fig. 10, Fig. 13; Fig. 14; Fig. 17). Oval buckles made of silver from Grave 3 (Fig. 19), glass cups from Grave 3 and 18 (Fig. 1; Fig. 24), a comb with bell-shaped handle blades from Grave 14 (Fig. 20) all indicate Period D2/D3, the middle of the $5^{\text {th }}$ century. Other finds, such as a cast, small bow brooch with three knobs from Grave 6 (Fig. 18), are more likely to date to the second half of the $5^{\text {th }}$ century. Glassware have been found in four burials, which can also be said to be common in the $5^{\text {th }}$ century. These glass cups differ from the late Roman glassware tradition of Pannonia in terms of their production, but they have good analogues in the area.
The Murga-type jug placed in Grave 6 and the small, grainy pot both are associated with the ceramic material of the settlement. We should also mention the perforated silver coin of Grave 14, a siliqua of Valentinian III minted between $\mathrm{AD} 422-455$, which provides a terminus post quem date of the grave and, due to the small size of the site and its short period of use, the entire cemetery and settlement.

The settlement and cemetery analyzed in our study display a new type of material culture compared to late Sarmatian sites. This material culture is not unique in the region, we can count on several similarities between the mostly unpublished sites excavated in the vicinity of Nyíregyháza (Fig. 16). As regards the ethnicity of the founders of the settlement and burial ground, we can say that a group of the heterogenous Hun-period population lived here during the transition period of the last years of the Hun Empire and the formation of the Gepid Kingdom. The site represents the burial customs, costume and objects of use that were widespread in the Carpathian Basin in the middle third and second half of the $5^{\text {th }}$ century.

Open Access. A cikk a Creative Commons Attribution 4.0 International License (https://creativecommons.org/licenses/by/4.0) feltételei szerint publikált Open Access közlemény, melynek szellemében a cikk bármilyen médiumban szabadon felhasználható, megosztható és újraközölhető, feltéve, hogy az eredeti szerző és a közlés helye, illetve a CC License linkje és az esetlegesen végrehajtott módosítások feltüntetésre kerülnek. (SID_1) 